\title{
HCP /J8659-01/4
}

\author{
PLANNING MANUAL FOR \\ ENERGY RESOURCE DEVELOPMENT \\ ON INDIAN LANDS
}

\section{(Formerly "Comprehensive Analysis of Issues Regarding Energy Resource Development on Indian Reservations")}

\author{
Volume IV--The ENvironment
}

\author{
Prepared for the \\ U.S. DEPARTMENT OF ENERGY
}

MARCH 1978

ERNST \& ERNST

This nport wa prepared on in account of work eponsored by the United States Government. Neither the United States nor the United States Department of Energy, wor any of their employees, nor any of their contractors, subcontracton, of their enployees, makes eny warranty, express or bmplied, or enumes any legat liability or respontibility for the mccuncy, completeness or viefuines of any information, apparatus, product or process diacloued, of mepresents that its use would not infringe privately owned rights. WASHINGTON, D.C. 


\section{DISCLAIMER}

This report was prepared as an account of work sponsored by an agency of the United States Government. Neither the United States Government nor any agency Thereof, nor any of their employees, makes any warranty, express or implied, or assumes any legal liability or responsibility for the accuracy, completeness, or usefulness of any information, apparatus, product, or process disclosed, or represents that its use would not infringe privately owned rights. Reference herein to any specific commercial product, process, or service by trade name, trademark, manufacturer, or otherwise does not necessarily constitute or imply its endorsement, recommendation, or favoring by the United States Government or any agency thereof. The views and opinions of authors expressed herein do not necessarily state or reflect those of the United States Government or any agency thereof. 


\section{DISCLAIMER}

Portions of this document may be illegible in electronic image products. Images are produced from the best available original document. 


\section{PREFACE $1 /$}

This is one of five volumes constituting the "Planning Manual for Energy Resource Development on Indian Lands." (The title of the final draft report, dated October 1977, was "Comprehensive Analysis of Issues Regarding Energy Resource Development on Indian Reservations.") The other four volumes produced under this contract are:

$$
\begin{aligned}
& \text { "Volume I - Benefit-Cost Analysis" } \\
& \text { "Volume II - Management and Contractual Arrangements" } \\
& \text { "Volume III - Manpower and Training" } \\
& \text { "Volume V - Energy Information and Clearinghouse Design" }
\end{aligned}
$$

In addition to these five separate reports, there is an Executive Summary covering the key points from each of the individual task reports. The Executive Summary is intended for wide distribution and has been written in non-technical language.

If The reader should be aware that the Energy Research \& Development AdminIstration (ERDA), Federal Energy Administration (FEA), Federal Power Commission (FPC), and some divisions of the Department of the Interior (DOI) were reorganized into a consolidated U.S. Department of Energy (DOE) effective October 1,1977 . The DOE is in the process of being reassigned accordingly. As a result, some of the source and/or telephone numbers listed in this manual may have been changed. If Information of a specific nature is desired, and this manual does not provide sufficient detail to obtain it, the reader should call the DOE general information number: (202) 252-5000. 
TABLE OF CONTENTS

Page

PREFACE

LIST OF EXHIBITS

iii

I. INTRODUCTION ..................... I-1

II. THE ENVIRONMENTAL IMPACT STATEMENT (EIS) PROCESS AND ITS ;

RELATIONSHIP TO INDIAN NATIONS . . . . . . . . . . . . II-1

Introduction .................. II-1

The EIS Process ................. . . II-2

The EIS Process for Energy Resource Projects on

Indian Lands .................... II-23

The Tribal EIS Process . . . . . . . . . . II-26

Enhancement of Tribal Input to the EIS Process ..... II-31

Enhancement of Tribal Awareness ......... II-33

Direct Tribal Input to the EIS Process . . . . . II-33

III. REVIEW OF ISSUES INADEQUATELY ADDRESSED IN ENVIRONMENTAL

IMPACT STATEMENTS .................... III-1

Introduction .................... III-1

Tribal Concerns Inadequately Addressed in EIS's . .... III-3

Information Needed to Address Tribal Environmental

Concerns Adequately . . . . . . . . . . . III-8

Physical Impacts . . . . . . . . . . . III-11

Social and Cultural Impacts . . . . . . . . III-13

Summary Checklist . . . . . . . . . . . III-17 
IV. LAWS AND REGULATIONS PERTAINING TO ENERGY OPERATIONS ON

INDIAN LANDS . . . . . . . . . . . . . . . IV-1

Introduction .................. IV-1

Overview of Major Federal Environmental Laws and Regulations that Affect Energy Development on Indian Lands . . IV-2

The Atomic Energy Act . . . . . . . . IV-15

The Clean Air Act Amendments of 1970 (PL 91-604) and 1977 (PL 95-95) ................. IV-17

Federal Environmental Pesticide Control Act of 1972 (PL 92-516) . . . . . . . . . . IV-26

Federal Water Pollution Control Act (FWPCA) Amendments of 1972 (PL 92-500) . . . . . . . . . . . IV-27

Mining Safety Acts . . . . . . . . . . IV-32

Noise Control Act of 1972 (PL 92-574) . . . . . . IV-34

Occupational Safety and Health Act of 1970 (PI 91-596) . . . . . . . . . . . IV-35

Solid Waste Disposal Act (SWDA) (PL 89-272), Resource Conservation and Recovery Act (RCRA) of 1976 (PL 94-580) . . . . . . . . . . . . IV-38

Surface Mining Control and Reclamation Act of 1977 (SMCRA) (PL 95-87) ........... IV-40 Toxic Substances Control Act of 1976 (PL 94-469) : IV-44 Tribal Trust Responsibilities: Lease Management . IV-44 Tribal Trust Responsibilities: Proposed Changes . IV-50

Implementation Issues and Problems . . . . . . . IV-53

The Effectiveness of Existing Performance

Standards ................. IV-55

The Effectiveness of the Administration and Enforcement of Enviromental Controls ....... IV-63

Tribal Options to Strengthen Environmental Controls . . IV-74

Tribal Policy Decisions............ IV-75

Alternative Control Measures . . . . . . . . IV-76

Program Standards and Procedures . . . . . . IV-81

Resource Requirements . . . . . . . . . . IV-84 
LIST OF EXHIBITS

Exhibit

No.

II-1

II-2

$I I-3$

II-4

II-5

$I I-6$

III-1

III-2

IV-1

IV-2

IV-3

IV-4

IV-5
Title

Page

Preparation and Review of Environmental Impact Statements

Under the CEQ Guidelines . . . . . . . . . . . . II-5

Areas of Environmental Impact ........... . II-9

Examples of Agency Criteria for Identifying "Major

Federal Actions that Affect the Environment" . . . . . . II-12

Bureau of Reclamation: Listing of Social Indicator

Variables and Cultural Evaluation Criteria Used for

Project Planning . . . . . . . . . . . . II-16

Tribal Involvement in the EIS Process . . . . . II-28

Strengths and Weaknesses of EIS Process for Projects on

Indian Lands . . . . . . . . . . . . . II-32

Social and Cultural Concerns Addressed and Not

Addressed in Environmental Impact Statements . . . . . III-10

Environmental Impact Statement Check1ist . . . . . . III-21

Glossary of Terms . . . . . . . . . . IV-4

Major Federal Environmental Laws and Regulations

Affecting 011 and Gas Development . . . . . . . . IV-6

Major Federal Environmental Laws and Regulations

Affecting Coal Development ... . . . . . . . . IV-8

Major Federal Environmental Laws and Regulations

Affecting Uranium Development . . . . . . . . IV-10

Major Federal Environmental Laws and Regulations

Affecting 0il Shale Development . . . . . . . . IV-12 
Exhibit

No.

$\underline{\text { Title }}$

$\underline{\text { Page }}$

IV-6 Major Federal Environmental Laws and Regulations Affecting Geothermal Development .......... IV-14

IV-7 Non-Attainment AQCRS, 1976 . . . . . . . . IV-22

IV-8 Effectiveness of Existing Performance Standards: 0i1 and Natural Gas .. . . . . . . . . . IV-56

IV-9 Effectiveness of Existing Performance Standards: Coal ....................... IV-57

IV-10 Effectiveness of Existing Performance Standards: Uranium Mining and Milling . . . . . . . . IV-58

IV-11 Effectiveness of Existing Performance Standards: Other Areas of Concern ............ IV-61

IV-12 Overview of Program Evaluation Flow . . . . . IV-86

IV-13 Consolidated Program Ranking . . . . ..... IV-88

IV-14 Consolidated Program Summary . . . . . . . IV-90

IV-15 Program Area Evaluation Summary . . . . . . . IV-92

IV-16 Program Area Evaluation Summary . . . . . . . IV-93

IV-17 Program Area Evaluation Sumary . . . . . . IV-95 


\section{INTRODUCTION}

Many Indian tribes own rich deposits of very valuable energy. resources. Existing and proposed uses of these tribal resources range from limited development of small oil and gas fields to large-scale extraction and conversion of coal, uranium, and oil shale. The adverse environmental impacts of such projects may create a conflict between a tribe's environmental policles and its economic, employment, and other long-term goals. The purpose of this volume is to provide tribal decisionmakers with reference documents on the mechanisms that are avallable to resolve such conflicts.

This report focuses on the role of existing environmental laws In enabling tribes to achleve the needed balance among its objectives. Over a dozen major federal statutes have been enacted to achieve this purpose. One law, the National Environmental Policy Act (NEPA), provides procedures to ensure that environmental factors are Included in the Federal decision-making process. Numerous other laws, such as the Clean Air Act, have been enacted to prevent or control any negative environmental impacts of actual projects. This volume documents the key provisions of the laws and regulations, and discusses their effectiveness in meeting total needs. Also, tribal options to strengthen these mechanisms are 
highlighted. Sections II and III report on the role of NEPA in tribal development decisions. Section IV reviews those laws and regulations that control project operations.

Section II documents the basic procedures governing NEPA's Environmental Impact Statement (EIS) process and the manner in which they have been applied to developments on Indian lands. After presenting an overview of the guidelines used by the Department of the Interfor, the section highlights the strengths and weaknesses of the current procedures in meeting the needs of tribal decision-makers. This is followed by a discussion of steps that may be taken by tribes to change or better utilize the EIS procedures.

The third section focuses on the content of the EIS's that have been prepared for tribal energy developments. This analysis draws heavily upon a review of several Final Environmental Statements (FES's), Draft Environmental Statements (DES's), and environmental assessments pertaining to proposed profects on or near Indian reservations and upon our site visits to the reservations of the 22 members of the Council of Energy Resource Tribes (CERT). Section III identifies tribal issues that have been addressed Inadequately in past EIS's and suggests ways in which treatment of these concerns can be Improved.

Finally, Section IV presents a documentation of the provisions of other envirommental laws; discusses their strengths and weaknesses in preventing or controlling impacts; and reviews factors that should be considered by those tribes that wish to strengthen these mechanisms. 


\begin{abstract}
Ultimately, we hope that this topical report will become a working handbook for energy resource tribes that will assist in evaluating and resolving environmental concerns relating to the development of energy resources.
\end{abstract}

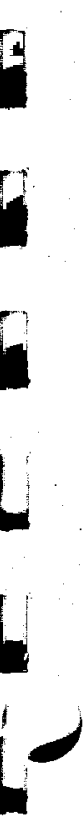


II. THE ENVIRONMENTAL IMPACT STATEMENT (EIS) PROCESS

AND ITS RELATIONSHIP TO INDIAN NATIONS1/

INTRODUCTION

The purpose of this section is twofold. First, it provides an understanding of how the Environmental Impact Statement (EIS) process works with respect to energy resource development projects and, second, it examines specific points in the process that the tribes can use to provide greater input regarding their specific concerns.

The section is presented in four parts. The first part is a discussion of how the EIS process works--how projects are proposed, assessed, reviewed, and approved (or disapproved). Sumaries of several Federal agency guidelines are presented. These include the guidelines of the council on Environmental Quality (CEQ), whose role is to establish the basic structure of the EIS process, and the Bureau of Indian Affairs (BIA) and the Bureau of Reclamation (BR), which are the agencies most often responsible for preparing EIS's for energy projects on Indian lands.

The second subsection describes the responsibilities of and procedures used by the BIA and the $B R$ in preparing and reviewing EIS's for energy resource projects on Indian lands. The third subsection includes an overview of a typical tribal EIS review process. Finally,

1/ The regulations for preparing EIS's are being revised by the Council on Environmental Quality. Therefore, some of the procedures described here will be changed. All tribes should obtain copies of these new guidelines before preparing or reviewing environmental assessments. 
we present a summary of the strengths and weaknesses of the EIS process from a tribal viewpoint and discuss the points in the process that could be used by the tribes to further enhance their input.

\section{THE EIS PROCESS}

In this subsection, we analyze both the EIS process and the basic structure established by the CEQ and the principal federal agencies involved in implementing that process.

Pursuant to the National Environmental Policy Act (NEPA - PL 91-190) and Executive Order 11514 (35 FR 447), any major federal action that significantly affects the quality of the human environment requires the preparation of an EIS. This mandate requires agencles to build into their decision-making process consideration of the effects of a proposed action on the environment. The purpose of the mandate is to minimize potential adverse effects of proposed projects on the human environment and also to promote understanding and harmony between man and his environment. An action may be proposed by a public sector agency or private sector group and may be included in one of three general categories: (1) recommendations for legislative actions, ranging from new program initiatives to budget appropriations; (2) new and continuing projects and program activities supported in any way by federal funds or involving a federal permit, license, or other entitlement for use; or (3) the making or modification of federal regulations or other administrative actions. Actions lacking direct federal control (e.g., actions funded using revenue-sharing funds distributed to state and local governments) are not included. Each federal agency maintains a list of project types within its jurisdiction that may significantly affect the environment so as to require the preparation of an EIS. 
Energy resource development projects on Indian lands are classified under category (2) above because a federally approved lease is usually required. In 1972, the Tenth Circuit Court ruled that NEPA does apply to leasing of Indian lands because federal (BIA) approval of leases is required (Davis v. Morton, 469 F. 2nd 593, 10th Cir. 1972). The court explains that the "only involvement necessary by. (the) federal government to constitute a major federal action requiring (an) environmental impact report is the approval or licensing of a project."

The BIA has since interpreted this decision to require the preparation of an EIS for an energy development project when BIA/federal approval is required (e.g., a lease agreement, license or permit) and the project is expected to have a significant impact on the human environment. For cases in which mineral development does not involve a lease but for which BIA approval is required (e.g., a mining joint venture), an EIS would be required if the project were expected to have a significant impact on the human enviromment. $1 /$ Projects that require federal BR approval include water sale contracts under the authority of the Reclamation Project Act of 1939 and subsequent acts (e.g., a power plant or coal mining and gasification complex). Other specific federal acts and regulations that relate to energy resource development projects on Indian lands are presented in Section IV of this report. Ongoing major federal actions that were begun before the passage of NEPA, but for which additional Federal approval is necessary, may also require the preparation of an EIS. For example, the Navajo Indian Irrigation Project in the San Juan Basin of New Mexico was authorized in 1962 and partly constructed before an EIS was finally filed in 1976.

1/ There remains some degree of uncertainty about the BIA's "official" position on this issue. 
The CEQ, Preparation of Environmental Impact Statement Guidelines $1 /$ (40 CFR Part 1500), provides the necessary procedures for the EIS requirements of NEPA. The basic steps in this process are described below (major steps are underscored). Exhibit II-1 provides an overview of the process from the time a project is proposed until a final administrative decision is reached. For every proposed federal action, whether inftitated by a private or public agency, a responstble federal agency must be designated. Usually, the potentially involved agencies will come to agreement on an appropriate responsible agency by considering: (1) the area of expertise required to assess the project; (2) the degree of involvement required; and (3) the timing of the actions involved. CEQ may become Involved upon agency request to aid in resolving the problem of lead agency determinations.

Almost all major projects are of an interdisciplinary nature, and if deemed appropriate, several agencles may agree either to share responsibility in a joint effort of preparing an environmental statement or to provide input to a lead agency. Multi-agency efforts are not arranged frequently because of administrative difficulties experienced in coordinating separate inputs. However, some agencies are required by law to provide input. For example, under the requirements of 25 CFR 177, the U.S. Geological Survey (USGS) is required to conduct a preliminary environmental survey on Federal and Indian lands involved in proposed mineral development projects. Also, under the requirements of 25 CFR 132, an archeological survey must be conducted where potentially significant cultural or historic resources may be involved.

\section{1/}

A11 quotations in this discussion are from the CEQ guidelines, except where noted. 
EXHIBIT II-1

PREPARATION AND REVIEW OF ENVIRONMENTAL IMPACT STATEMENTS UNDER THE CEQ GUIDELINES

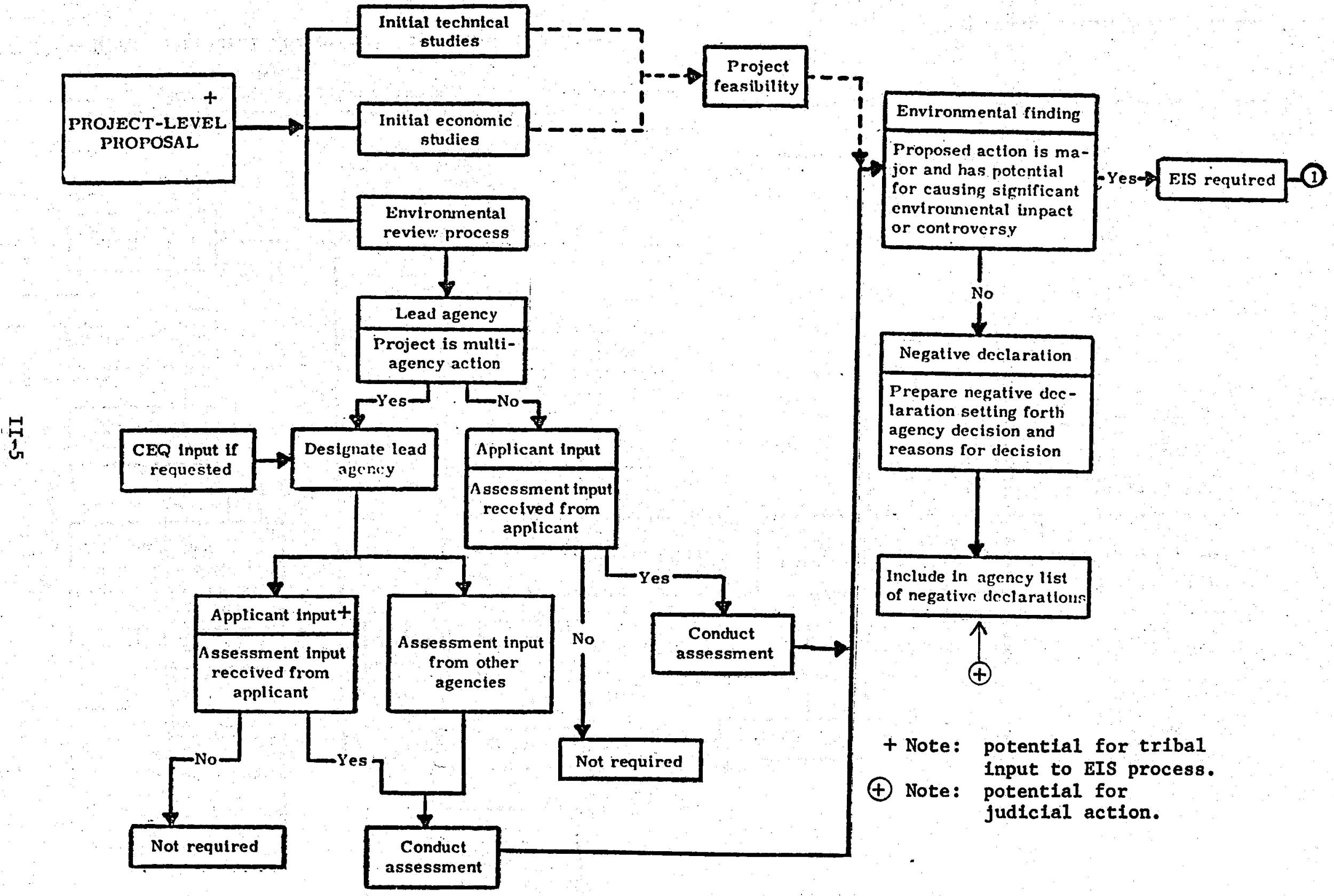




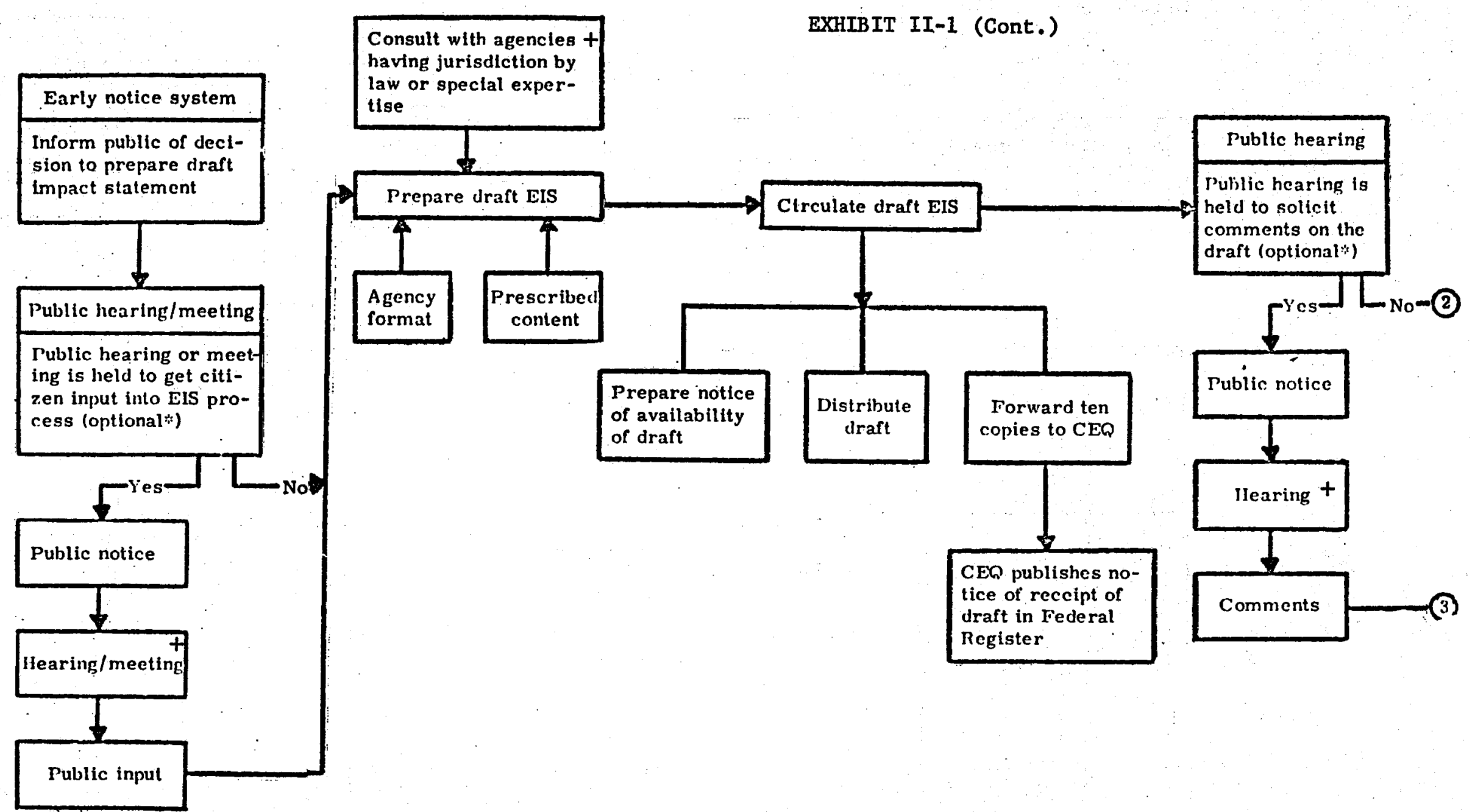

\section{Draft ĖIS}

Issued.

*NOTE: Refer to agency guldelines concerning necessity of holding public hearings, meetings, etc.

+ NOTE: Potential for tribal Input to EIS process.

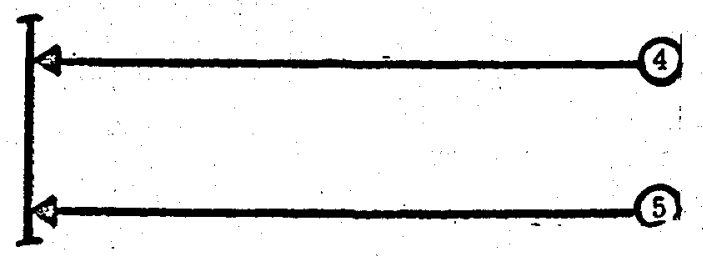


Occasionally, the process described above may be sidetracked if an appropriate responsible agency does not have sufficient staff resources to assume the responsibility for an additional project. In this case, another agency may agree to accept responsibility for EIS preparation. Such decisions are handled on a case-by-case basis.

Most energy resource development projects on Indian lands fall under the "lead agency jurisdiction" of either the Bureau of Indian Affairs or the Bureau of Reclamation. The BIA is responsible for approving leases for mineral development projects on Indian lands, and the BR is responsible for approving water sale contracts for similar projects. These responsibilities will be explained further in the next section.

\section{An agency responsible for preparing an environmental statement must} identify what actions significantly affect the environment. The effects to be considered include, but are not limited to, those listed in Exhibit II-2. Several of these areas should be critically examined where projects on Indian lands are involved, including "energy supply and natural resources development," "neighborhood continuity and character," and "impacts on low-income populations." Appendix II of the CEQ guidelines contains a more complete listing that includes agencies with jurisdiction by law or special expertise. The CEQ criterion for determining what actions significantly affect the human environment is to identify those major federal actions that "directly affect human beings or Indirectly affect human beings through adverse effects on the environment." Some agencies have subsequently developed more specific criteria and methods to identify these actions and their impacts on the environment by program area. However, decistons are still usually reached on a caseby-case basis. 
EXHIBIT II-2*

AREAS OF ENVIRONMENTAL TMPACT

$\underline{\text { AIR }}$

- Alr Quality

- Weather Modification

WATER

- Water Quality

- Marine Pollution, Commercial Fishery Conservation, and Shellfish Sanitation

- Waterway Regulation and Stream Modification

FISH AND WILDLIFE

SOLID WASTE

NOISE

RADIATION

HAZARDOUS SUBSTANCES

- Toxic Materials

- Food Additives and Contamination of Foodstuffs

- Pesticides

- Transportation and Handling of Hazardous Materlals

ENERGY SUPPLY AND NATURAL RESOURCES DEVELOPMENT

- Electric Energy Development, Generation, and Transmission and Use

- Petroleum Development, Extraction, Refining, Transport, and Use

- Natura1 Gas Development, Production, Transmission, and Use 
EXHIBIT II-2 (Cont.)

ENERGY SUPPLY AND NATURAL RESOURCES DEVELOPMENT (Cont.)

- Coal and Minerals Development, Mining, Conversion, Processing, Transport, and Use

- Renewable Resource Development, Production, Management, Harvest, Transport, and Use

- Energy and Natural Resources Conservation

LAND USE AND MANAGEMENT

- Land Use Changes, Planning and Regulation of Land Development

- Public Land Management

PROTECTION OF ENVIRONMENTALLY CRITICAL AREAS - FLOODPLAINS, WETLANDS, BEACHES AND DUNES, UNSTABLE SOILS, STEEP SLOPES, AQUTFER RECHARGE AREAS, ETC.

LAND USE IN COASTAL AREAS

REDEVELOPMENT AND CONSTRUCTION IN BUTLT-UP AREAS

DENSITY AND CONGESTION MITIGATION

NEIGHBORHOOD CHARACTER AND CONTINUITY

IMPACTS ON LOW-INCOME POPULATIONS

HISTORIC, ARCHITECTURAL, AND ARCHEOLOGICAL PRESERVATION

SOIL AND PLANT CONSERVATION AND HYDROLOGY

OUTDOOR RECREATION

* Source: Council on Environmental Quality, Federal Register, Vol. 38, No. 147. 
A preliminary environmental assessment is generally prepared by the responsible agency to determine the significance of the effects of the proposed action on the environment. If the effects are determined to be significant, a Draft Environmental Statement (DES) must be prepared. If the determination is negative, a Negative Declaration must be prepared and entered as such in both the agency's records and $C E Q$ 's records. In some cases the proposed developer may supply much of the information used to prepare a preliminary assessment.

The specific criteria that were developed by the BIA and the BR for impact assessment are presented in Exhibit II-3. Neither of the two 1ists in Exhibit II-3 includes social, economic, or cultural criteria for identifying major federal actions that affect the environment. Both sets of criteria emphasize physical factors over socioeconomic factors of the human environment. Such terms as "cultural resources" (BR) and "cultural site" (BIA) are not defined, which may lead to omitting these criteria more easily than to examining them.

Since the publication of its criteria in the Federal Register in 1972, the BR has developed a more detalled set of guidelines in response to the planning policies and standards established by the Water Resources Council I/ that are slowly being integrated into project assessment procedures in the field. Some examples of the socioeconomic and cultural "indicator" variables that are being used are presented in Exhibit II-4. More sophisticated social impact analysis techniques have also been developed that are being integrated into BR analysis procedures. - A discussion of cultural and other 1/ Water Resources Council, "Proposed Principles and Standards for Planning Water and Related Land Resources," Federal Register, Vo1. 36, No. 245, Part II.

$\underline{21}$

Fitzsimons, Stephen J., Lorrie I. Stuart, and Peter C. Wolff, A Guide to the Preparation of the Social Well-Being Account-Social Assessment Manual, Abt Assoclates, Inc., prepared for Bureau of Reclamation, July 1975. 


\section{EXHIBIT II-3}

EXAMPLES OF AGENCY CRITERIA FOR IDENTIFYING 'MAJOR FEDERAL ACTIONS THAT AFFECT THE ENVIRONMENT"

\section{BUREAU OF INDIAN AFFAIRS CRITERIA* (INCLUDES TYPES OF EFFECTS ONLY)}

"The project will be identified as a major Federal action significantly affecting the quality of the human environment when the assessment reveals a significant effect on one or more of the following types of conditions :

(1) Rare or endangered species

(2) Wild or scenic areas

(3) Archaeological, cultural, or historical sites

(4) The health or safety of the public

(5) Fragile or unstable soils on steep slopes

The above listing is not all-inclusive. In addition, there may be other conditions affected that should be included in this list."

\section{BUREAU OF RECLAMATION CRITERIA** (INCLUDES TYPES OF ACTIONS AND EFFECTS)}

-- Types of Actions

(1) "Planning Federal water and related land resources projects and programs. Example: irrigation, municipal and/or industrial water, hydroelectric projects and atmospheric water resources management programs"

(2) "Research or investigations where the on-the-ground tests involve treatment or modification of natural resources"

(3) "Construction activities on Federal water and related land resource projects and programs. Examples: Irrigation, municipal and/or industrial water, hydroelectric projects which have not been covered by a prior environmental statement, or where there has been a major change in design from that presented in the authorization report and environmental statement accompanying that report and major new transmission lines or transmission line relocations" 


\section{EXHIBIT II-3 (Cont.)}

\section{BUREAU OF RECLAMATION CRITERIA (Cont.)}

(4) "Such other activities as:

- Changes in river operation or reservoir operation procedures

- Major dam modification programs

- Major canal modification programs

- Vegetative management programs

- Major acquisition leases, exchanges, or disposals of lands

- Major public service developments, such as recreation facilities developed after the initial construction period

- Major power plant modification programs"

(5) "Actions relating to natural or cultural resources:

- Acquisition or disposal of the resources

- Regulation, permission, prohibition, or other institutional control of uses

- Their operational or physical management

- Construction or operation of various structures to manage them

- Recommendations of comprehensive, program, or project plans for their management for which $1 \mathrm{~m}-$ mediate authorization is anticipated based on recommendations made"

(6) "Recommendations or favorable reports to the Congress relating to legislation that changes the legal or administrative status afforded to the environment and legislation relating to appropriations for programs or projects that result in significant impact on the environment" 
EXHIBIT II-3 (Cont.)

BUREAU OF RECLAMATION CRITERIA (Cont.)

(7) "Projects, programs, and continuing activities including research:

- Directly undertaken by the Bureau of Reclamation

- Supported in whole or in part through Federal contracts, grants, subsidies, loans, or other forms of financial assistance

- Involving a Federal lease, permit, license, certificate, or other entitlement for use"

(8) "Recommendation or adoption of policies, principles, standards, procedures, regulations, and plans which affect the environment through changes in management, operation or maintenance of facilities or which modify the legal or administrative protection afforded environmental resources"

-- Types of Effects

(9) "Activities that will significantly affect the following will require an enviromental statement:

- Rare or endangered species--plant, animal, or fish

- Formally classified areas such as Wilderness Areas, Primitive Areas, Wild and Scenic Rivers, National Recreation Areas, Scenic Areas, Historical Areas, Archeological Areas, Geological Areas, National Trails, National Wildlife Refuges, State Wildiife Refuges or Management Areas, parks or similar locally designated areas, and areas being studied for classification for such purposes

- Municipal watersheds

- Reservoir operation (major changes)

- Large roadless areas

- Scenic attractions

- Wetlands and estimates

- Freeflowing streams or major channels in regulated streams 


\section{EXHIBIT II-3 (Cont.)}

BUREAU OF RECLAMATION CRITERIA (Cont.)

- Alr quality

- Water quality

- Key wildife or fish habitat"

*Source: Bureau of Indian Affairs Manual, Supplement 1, August 1973.

**Source: Federa1 Reg1ster, Nov. 23, 1972. 
BUREAU OF RECLAMATION: LISTING OF SOCIAL INDICATOR

VARIABLES AND CULTURAL EVALUATION CRITERIA

USED FOR PROJECT PLANNING*

SOCIAL INDICATOR VARIABLES:

(1) Population Characteristics

(a) Resident, age, sex, race

(b) Non-resident-numbers on in-migration

(c) In-migration--age, sex, race, urban-rural origin, educational level, occupation, cultural profile, marital status

(d) Out-migration--age, sex, race, urban-rural origin, educational level, occupation, cultural profile, marital status

(e) Family characteristics--number, average size, household data, divorce, sex of head of household, number of children

(2) Economic Factors

(a) Labor force--employment, unemployment, unemployment insurance

(b) Occupations by Industry

(c) Income levels

(3) Welfare

(a) Number and kinds of public social welfare programs, number of persons served

(b) Number and kinds of private social welfare agencies, number of persons served

(c) Number and kinds of children's agencies, number of persons served

(d) Data indlcating needs for welfare institutions, 1.e., income, consumption patterns, child abuse, broken families, inability to utilize, urban infrastructure, employment facilities-in-migrant labor 


\section{CULTURAL EVALUATION CRITERIA:}

(1) Quantity Factors

(a) The number of Individuals associated with each type of culture.

(b) The extent and intensity of geographic distribution of the cultures, and of land considered traditionally or religiously significant by such cultures

(2) Quality Factors

(a). Extent to which members of the cultural group Identify with the culture

(b) Contribution of the culture to the life-style of others

(c) Importance of the land, the earth, or particular sites or areas to the people or cultures with which they are assoclated

(d) Extent of culture change Intruded or imposed from outside

* Source: Bureau of Reclamation, Guldelines for Implementing Principles and Standards for Multiobjective Planning of Water Resources, 1972. 
issues that are of concern to many tribes, but that are not clearly included in agency impact assessment criteria, is presented in Section III.

The preparation of a DES may involve several stages of assessment (intermediate working papers, proposed drafts, etc.) and review (informa1 requests for comments and meetings) that lead to the submission of a DES to CEQ. Consultation during the DES preparation should include all federal and state agencies with jurisdiction by law or special expertise plus any other groups or individuals known to be interested in the agency's activities. Detailed criteria such as those presented in Exhibit II-4 are a valuable basis for formulation of tribal concerns and environmental priorities for input to an EIS.

The public is also required to receive early notice of major actions for which a DES is being prepared. In this connection, agencies are urged to: (1) identify pending actions, such as approval of planned energy projects, in a list of environmental statements being prepared; (2) revise the list at regular intervals; and (3) make the list available for public inspection on request. $\mathrm{CEQ}$ also regularly publishes a similar list in the Federa1 Register. Similar lists and notification procedures are also required for Negative Declarations. However, if the responsible agency deems it appropriate, no further review of a Negative Declaration is necessary.

The contents of environmental statements (including Negative Declarations) as specified in the CEQ guidelines should include:

(1) A description of the proposed action and its purpose, and a description of the environment affected. Of particular importance here is the requirement to identify, as appropriate, population and growth characteristics of the affected area and any population and growth assumptions used to justify the project or to determine secondary population or growth impacts. 
(2) The relationship of the proposed action to land-use plans, policies, and controls for the affected area

(3) The probable impact of the proposed project on the environment. Among the factors to consider are those listed in Exhibit II-2, including both direct and indirect impacts on population and growth. "Population and growth impacts should be estimated if expected to be significant ... and an assessment made on the effect of any possible change in population patterns or growth upon the resource base, including land use, water, and public services of the area in question."

(4) Alternatives to the proposed action, including those that may not be within the authority of the responsible agency. "A rigorous exploration and evaluation of the impacts of all reasonable alternative actions ... that might enhance environmental quality or avold some or all of the adverse environmental effects is essential. Sufficient analysis of such alternatives and their environmental benefits, costs, and risks should accompany the proposed action through the agency review process. . ."

(5) "Any probable adverse environmental effects which cannot be avolded (such as . . undesirable land use patterns, ... urban congestion, threats to health...)"

(6) "The relationship between local short-term uses of man's environment and the maintenance and enhancement of long-term productivity"

(7) "Any Irreversible and irretrlevable commitments of resources that would be involved in the proposed action should it be implemented... ."

(8) "An Indlcation of what other interests and considerations of federal policy are thought to offset the adverse environmental effects of the proposed action." 
In preparing a DES, the CEQ requires that "agencies should make every effort to convey the required information succinctly in a form easily understood, both by members of the public and by public decisionmakers." The CEQ also requires that, upon availability of a DES for review, each agency should make provisions for facllitating the comment of public and private organizations and individuals by making copies avallable to those that request them and by devising methods for publicizing the existence of draft statements. Examples of practical methods include news releases to the local media and maintenance of a distribution list of parties known to be Interested in the agency's activities. The agency must notify CEQ of DES avallability for fnclusion in the Federal Register list of DES's made avallable during the previous week. There are no other set requirements for public Involvement, and the extent of project publicity via news releases to local media is often decided by the appropriate field office of the responsible agency. Public hearings are not required but are usually held for controversial projects at least 15 days after the public is notified of DES avallability. Copies of the DES are distributed to all federal and state agencles involved by legal jurisdiction or special expertise, to state clearinghouses, and to anyone else upon request.

Comments may be made orally or in wtiting at the public hearing: Substantive written comments concerning the DES must be received within 45 days of the notice of DES availability and must be attached to the Final Environmental Statement (FES), whether or not the response deems modification of the text necessary. Agency guidelines may require that a sumary of any public hearings that may have been held subsequent to DES avallability be attached to the FES. 
EIS review comments must be adequately addressed in the Final

Environmental Statement by the responsible agency, and projects may be modified

as a result of these comments. Frequently, an agency response to these comments requires changes in the EIS text that either expand or modify previous analysis results. In some cases, major project modifications may be required. These instances usually involve projects that are shown to violate existing environmental or procedural standards. Some examples of changes include: modification of oil field recovery techniques to limit water flood injection pressures in order to prevent ground water contamination (under proposed EPA regulations); installation of additional emission control devices to decrease hazardous air pollutants on a power plant; or a change in lease acreage to avold disrupting a major archeological find.

Desired project modifications based upon issues for which environmental quality standards have not been established (e.g., for employment or for cultural preferences) are less 11kely to be successful. This is particularly true when such "intangible" factors as the importance of nature's pristine qualities to the cultural values of a tribe's members are considered. Also, there are no legal standards under which the government can require and enforce mitigating measures for many of these kinds of issues.

The preparing agency must submit coples of the FES to the CEQ, the EPA, all commenting agencies, and all individuals who request a copy. A minimum of 30 days 1 s required for final review and comments before any administrative action can be taken (i.e., agency approval or disapproval of the proposed project). This time period may run concurrently with a required minimum 90-day period (beginning with DES availability) before administrative action can be taken. 
In a recent survey of 70 federal agencies, the CEQ $1 /$ found that the average time required for preparation of a DES and release of an FES ranged from 7 months (Department of Commerce) to several years (U.S. Department of Agriculture, Soll Conservation Service). The BIA averages 9 months, while the $B R$ averages 31 months. The wide range of time is affected by the complexity of the project, the experience of the staff preparing the document, and project priority. (EIS's for low-priority projects may be prepared over a longer time frame,) Significant delays can also result if: litigation is brought against the project.

Parties with a standing interest can bring suit challenging compliance with procedural requirements or the adequacy of an FES. In fact, NEPA-related litigation can be initiated after: (1) a Negative Declaration has been filed for those projects that have been determined by the responsible agency to have no significant impact on the human environment; or (2) after a Final Environmental statement has been filed for projects having significant impacts. Between January 1970 and July 1975, there were 654 cases, completed or pending, that involved some NEPA issue. In 363 cases, the plaintiffs contended that an EIS was required for projects for which a Negative Declaration has been filed. The remaining 291 cases challenged the adequacy of an EIS that had been prepared. These figures contrast with the 6,000 DES's that were prepared during the same period and the 30,000 federal actlons that were assessed during 1975 alone to determine whether they would cause significant environmental effects. of all the cases completed, only 60 resulted in temporary infunctions, which ranged from a few weeks to the several months required to prepare an

1/ Environmental Impact Statements, An Analysis of Six Years' Experience by Seventy Federal Agencies, CEQ, 1976. 
adequate statement. Only four resulted in "permanent injunctions," but even in those cases the project was allowed to proceed after compliance with NEPA. Analysis of these facts results in two important points. First, it Is evident that the chance of success for project adversaries who wish to stop a project on NEPA-related grounds after the FES has been issued is very low. In most cases, procedural or technical violations can be corrected and the project will be allowed to proceed. Exceptions may occur in some cases. For example, a threat to an endangered plant or animal species or to an archeological find may be sufficient grounds to stop a project during any stage of project planning or construction.

Second, and perhaps more in line with the objectives of NEPA and the EIS process, is the fact that a tribe can effect modification of a project if 1t can be shown that adverse impacts or available mitigation measures have been underestimated or not addressed. Project modification must ensure that resultant environmental quality will be within the limits established by relevant environmental laws.

A requisite for successful litigation concerning either of these types of issues is expertise In a range of subject areas, including the natural sciences, the social sciences, mathematical and statistical forecasting, and legal counsel, to name a few. The Implications of the need for these professional resources are discussed more fully in Volume II.

THE EIS PROCESS FOR ENERGY RESOURCE PROJECTS ON INDIAN LANDS

In this section, the specific procedures and requirements of the BIA and the BR are reviewed as they relate to energy resource development projects on Indian lands. 
As noted previously, the assessment of projects concerning the development of energy resources on Indian lands has generally fallen under the legal jurisdiction of either the Bureau of Indian Affairs or the Bureau of Reclamation as the lead agency. This has resulted mainly because the first and most involved major federal action for most energy resource projects is either approval of a lease for lands held in trust for an Indian Nation (BIA jurisdiction) or approval of a water rights contract (BR jurisdiction). Energy resource projects that generally affect the environment to a degree that warrants preparation of an EIS Include surface mines (e.g., coal and uranium mines), coal gasification and electric power plants, water resource projects (e.g., irrigation projects), and possibly oil shale mining (as it becomes commercially feasible). Not all energy projects require an EIS. For example, federal land management agencies often determine that for onshore oil and gas developments, the preparation of an environmental assessment (pre-EIS evaluations) is sufficlent for the purposes of NEPA. Potentially adverse environmental impacts of oil and gas recovery can be mitigated using measures routinely required in drilling plans.

The field offices of the BIA and the BR are usually responsible for performing environmental assessments, making a determination of significance, and preparing an EIS if necessary. The procedures followed by these agencies generally conform to the CEQ guidelines; however, there are some variations that present potential problem areas from a tribal viewpoint. These are highlighted below:

- For projects that follow BIA procedures (advertised lease bids or BIA-approved lease negotiations), an EIS is generally prepared by the BIA prior to the tribe's approval of a lease. However, in cases where a tribe desires to negotiate a lease privately with a mineral company, an EIS is prepared by the BIA after the tribe has concluded its negotlations and submitted a lease agreement for BIA approval. In this latter case, a tribe must perform its own impact analysis in order to negotiate the most beneficlal environmental terms in the lease agreement. The BIA's EIS analysis is not available early enough to be used as a tool in formulating the specific provisions of the lease. 
- The extent to which tribal input is solicited and used for EIS preparation varies. The BIA guidelines $1 /$ specifically require the involvement of affected tribal organizations in the EIS consultation and review process. The BR's written guidelines $2 /$ do not require Indian consultation; however, in practice, the $B R$ consults with both the BIA and affected tribes throughout project planning. Neither agency routinely includes tribal members on an EIS task force, but in some cases tribes have been invited to participate. Indian EIS task force participation wi11 prove beneficial to Indian Nations if sufficient expertise is available to the tribes to perform substantive analysis.

- The practice of holding public hearings is not mandatory in the BIA guidelines; however, the BIA usually holds public hearings, mainly after a DES becomes available for review. There appear to be fewer public hearings in the earlier stages of the project planning than in the latter stages. On the other hand, the BR's guidelines $3 /$ require public hearings at both of these stages, and the BR is presently considering a comprehensive revision of its guidelines that will include additional provisions for full public involvement. In practice, both bureaus notify the public of scheduled hearings (after a DES becomes avallable) via press releases to the local news media and have on occasion postponed hearings upon request by an affected tribe.

- Specific criteria or methods for assessing socioeconomic or cultural impacts or mitigating measures do not adequately address tribal concerns. This is due largely to the fact that the state of the art of quantitative socioeconomic and cultural impact analysis is not advanced. CEQ, the National Science Foundation (NSF), and the Energy Research and Development Administration (ERDA) are currently funding studies to develop such criteria. 4 / As was shown in Exhibit II-4, the BR has developed a basic set of social indicator variables that could be used as a basis for 1dentifying tribal concerns and priorities on an individual project basis.

I/ Bureau of Indian Affairs Manual, Supplement 1.

2/ Federal Register, November 23, 1972 .

3/ Bureau of Reclamation Instructions, Series 350, General Instructions, Part 376, 1972 .

4) "Socioeconomic and Secondary Environmental Impacts of Western Energy Resource Development," by the University of Denver Research Institute, Resource Planning Associates, and Socioeconomic Associates, undèr CEQ Contract No. EQ6AC018, 1976-1977. 
In summary, the practices and procedures followed by the BIA and the BR involving the public in Indian-related energy resource development projects generally exceed the specific requirements of NEPA, although there appears to be a deficiency in the use of direct tribal input in EIs preparation. Existing agency guidelines for socioeconomic and cultural impacts assessment have generally been non-specific, primarily because there is a lack of state-of-the-art information on social well-being impact analysis. Also, interpretation of the CEQ guidelines by agencies that assist the BIA or BR in EIS preparation by assessing socioeconomic and cultural impacts may vary where Indian tribes are concerned.

THE TRIBAL EIS PROCESS

This section describes the general involvement of a tribe in the EIS process and some of the difficulties that are experienced.

The EIS process begins after a tribe has notified the BIA of its decision to offer land on a lease basis for development, or after an area has been proposed by the tribe and the BR for development of a water resources project. A preliminary assessment of the project's impacts by the BIA or BR marks the first step in the EIS process.

The tribes (per BIA guidelines) may be involved in the EIS process through consultation and during the review process. If the tribal members are consulted during EIS preparation, their coments should be used in the appropriate sections of the EIS. $1 /$ This would limit or alter the need to analyze the DES to the extent necessary when tribal concerns are not addressed. Although a tribe may favor the proposed project initially,

1/ Comments made in FES's by tribal members indicate that their inputs are not fully utilized. (See Section III.) 
in many cases its members are not fully aware of the potential adverse impacts unt11 the DES has been completed. Direct participation by tribal members in the preparation of an EIS is generally an exception to federal agency procedures. For example, tribal members were invited to serve as advisers in the preparation of the EIS for the Sherwood Uranium Project (Spokane Indian Reservation) and as EIS task force members for the Crow-Ceded Area Lease, Tracts II and III, Westmoreland Resources Project, but these were the only cases of such direct participation that we uncovered.

Upon DES completion, the tribal chairperson is the initial recipient of a DES released for review. From here the process varies from reservation to reservation as there may be more than one tribe located on the reservation, and different tribes have different individuals or comittees responsible for reviewing EIS's. For the most part, tribal review of an EIS follows the basic process presented in Exhibit II-5. The exhibit differentiates between tribal and federal agency responsibilities and indicates the points at which tribes can provide direct input to the EIS process.

Once it has been established, based on preliminary EIS review, that the proposed project will significantly affect the reservation and its inhabitants, the responsibility of review is delegated by the tribal chairperson to the appropriate party. The tribe will use its resources and usually acquire any outside expertise it may need if it is readily. available. Some tribes rely on the BIA for an evaluation of the adequacy of an EIS.

A written statement is then drawn up from the analysis and presented to the tribal chairperson by the reviewers elther privately, at a tribal council meeting, or at a public tribal meeting. If public hearings are held, an attempt is made to have a tribal member at the hearing to represent the tribal point of view. 


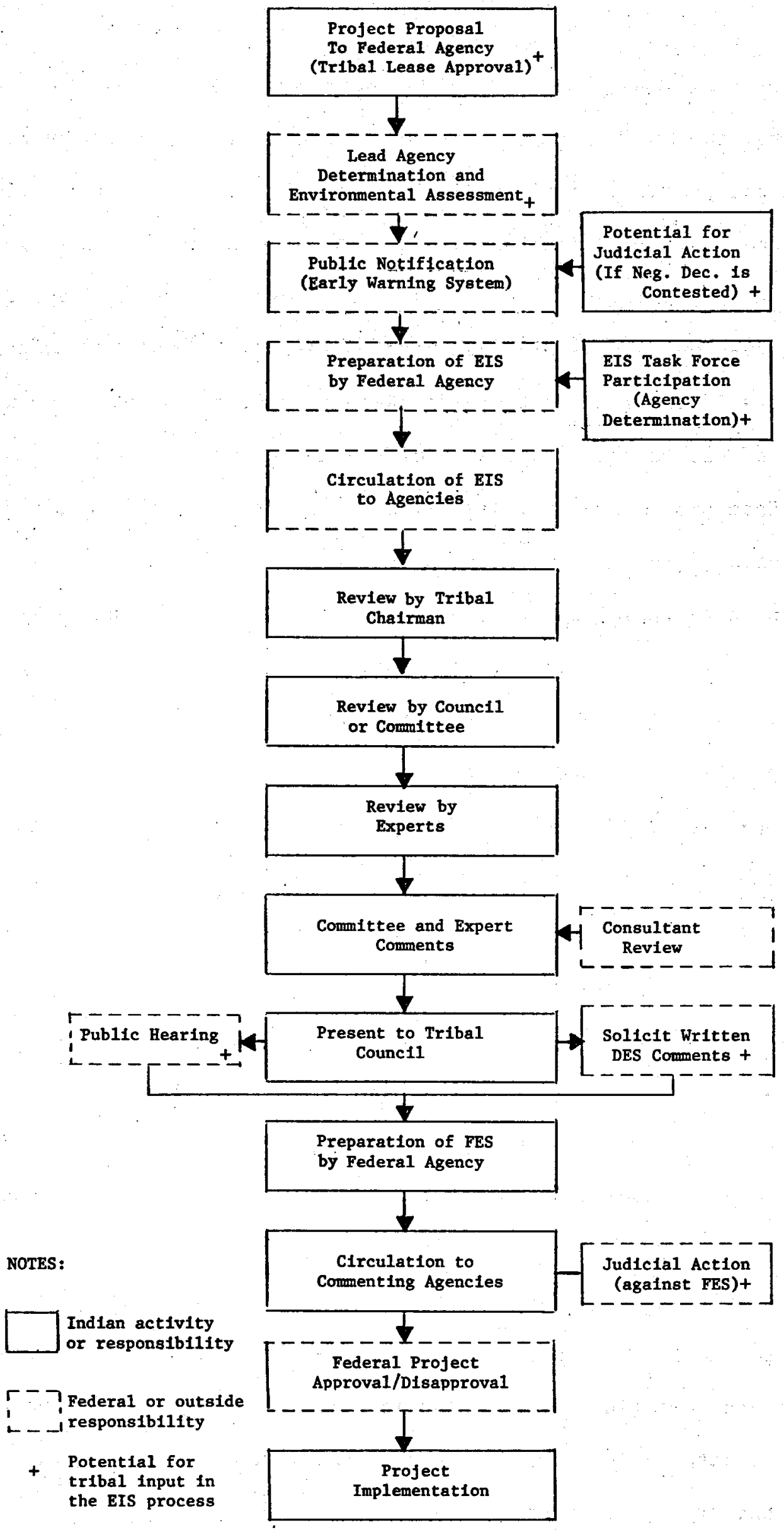


Although the tribal process is made up of several straightforward steps (see Exhibit II-5), there are many potential snags that may hold it up. The major problems in the EIS process at the tribal level are those of time, understanding the content of the EIS, language barriers, notification of EIS availability, and opinion differences about a project among tribal members (and among tribes if more than one is located on a reservation).

The system of analysis on the reservation does not always take place in a timely manner, a1though time is very important because DES comments must be received before the 45-day deadine. The period of review and comment could pass by before the appropriate review party has had time to analyze it because tribal members are often off the reservation for extended periods of time, consultants are not always readily available, and the importance of the deadline is not always understood by the tribe.

The language barrier is also a contributing factor to the delay in the EIS review process. The Navajos have considered having the EIS's translated into their native tongue so that more tribal members will have the opportunity to read them. The problem here is that this would create further delays. It is unlikely that a technical, multi-volume EIS could be translated, reproduced, distributed, reviewed, and commented upon In detail within the 45-day comment period. It might be possible to circulate translated summaries, but the lack of detall in a summary might also limit its value. It would be to a tribe's advantage to request that translations 
be prepared by the lead agency simultaneously with EIS preparation so that both versions would be available for review at the same time. The main reasons that translation services are not considered feasible by the BIA are high costs and an expected loss of technical meaning in translation. Therefore, decisions to provide translations would probably have to be made on a caseby-case basis.

Third, the tribes are not always aware of the availability of the EIS because the only CEQ-required notification is published in the Federal Register. Some of the tribes subscribe to this publication, but for many the major source of notification is through the BIA, because of its trust responsibility. There have been cases, however, in which the tribal member responsible for energy-related matters was not notifled. In at least one instance, the responsible tribal party became aware of an EIS only through the announcement of the public hearing regarding it. This allowed only a few days to acquire the EIS, review it, and make comments. The Implication here is that there is a need for regular monitoring of project energy sources.

Finally, there is much diversity of opinion concerning energy development among individual tribal members and among different tribes located on a single reservation. These controversies have caused conflicts among members within tribes. Increased communication concerning project development within and among tribes would contribute to more uniform understanding of problems and impacts. 
ENHANCEMENT OF TRIBAL INPUT TO THE EIS PROCESS

This subsection summarizes the main advantages and disadvantages of the EIS process from a tribal viewpoint, and also provides an analysis of the points in the process at which the tribes can further enhance their involvement and input.

A summary of the strengths and weaknesses of the existing EIS process from a tribal viewpoint is presented in Exhibit II-6. These points have been gleaned from the discussions presented throughout this section, from conversations with tribal representatives, and from relevant comments incorporated in the Final Environmental Statements.

The strengths presented in the exhibit are self-explanatory; however, the weaknesses need additional explanation. The discussion that follows examines some of the ways tribes can increase their input to the EIS process and overcome some of the inherent difficulties that they experience.

Having reviewed the EIS process, we feel that a tribe should be able to use the EIS process in two general ways--by increasing its overall awareness of project development and impacts, and by increasing its input to the process at those stages where the opportunity for public involvement is already bullt in. The areas that apply generally to all tribes are presented below. 


\section{EXHIBIT II-6 \\ STRENGTHS AND WEAKNESSES OF EIS PROCESS \\ FOR PROJECTS ON INDIAN LANDS}

\section{Strengths}

Provides analysis of project impacts (at no cost to tribes) that would otherwise be unavailable for decision making concerning lease agreements.

- Allows public intervention (by 1itigation) to contest filing of Negative Declaration on adequacy of EIS

- Allows public comment at hearings or as written response to EIS

- Some agencies solicit tribal input for EIS preparation on selected projects.
Weaknesses

EIS's for leases negotlated without BIA input are prepared after a lease agreement is signed by a tribe and submitted to the BIA for approval. This makes it necessary for a tribe to secure its own impact analysis as an input to the negotlating process when tribal leaders are negotiating privately (without direct BIA participation).

- Tribal members are consulted for EIS preparation at the discretion of the lead agency. EIS task force participation is not required.

- Public notification of EIS preparation or availability in the Federal Register and notification of public hearings in the local media are not effective for the tribes and tribal members who do not subscribe to these information sources.

- Preparation periods for public hearings teștimony (15 days minimum) and written DES comments (45 days minimum) are insufficient for tribes to obtain, review, and comment upon EIS adequacy.

- Public hearings are not required for all major federal actions but are held at the discretion of the lead agency.

- Tribal resources may be insufficient to review technical aspects of an EIS for accuracy.

- Language barriers limit the value of EIS's to many tribal members.

- Socioeconomic impact criteria are not emphasized in some federal agency impact identification or evaluatiou guidelines. 
Enhancement of Tribal Awareness

- Increased monitoring of public information sources covering project initiations, public hearing announcements, DES avallability, etc., by designated tribal members would serve to keep the awareness of tribal decision-makers more uniform. The primary sources referred to are the Federal Register, the BIA, the $B R$, and the local radio and newspaper media.

- Increased communications among tribes at various stages of project development would contribute to a more uniform sense of understanding of project impacts and tribal priorities. Although fully translated EIS's may not be easily incorporated into this information exchange, translated summaries provided by the tribes or the BIA may be useful.

- Ongoing technical and legal analysis of project developments by tribal analysts would facilitate the preparation of more substantive and timely comments for public hearings testimony, for a written DES comment, or for rebutting the findings - of a Negative Declaration.

- Stipulation by the tribe during contract negotiations of specific measures to be carried out by the contractor can be used to benefit tribal welfare. The types of stipulations included should be determined - on a case-by-case basis but could involve a wide range of considerations. (Specific types of stipulations are addressed in Volume II.)

Direct Tribal Input to the EIS Process

In addition to the observations made above that would increase tribal awareness and capability to deal with EIS-related lssues, there are several built-in polnts for public involvement in the process that the tribes can use to further enhance their input and welfare. These are summarized below.

- Where tribal consultation is solicited by a federal agency during EIS preparation, the tribe should use its resources to assemble a statement explaining its environmental concerns and priorities. These should be reviewed during subsequent consultations and compared with completed agency analysis. 
- Where the opportunity arises, either by solicitation or by request of the tribe, increased participation on EIS task forces by tribal analysts would aid in increasing the extent to which future EIS's address tribal environmental concerns. Tribal participation on an EIS task force is not a standard agency policy; however, increased tribal expertise in the natural and social sciences, economics, etc., and increased tribal requests for participation may effect a change in the extent of task force involvement.

- Submission of substantive oral testimony and written comments at public hearings (frequently held at the project initiation and DES review stages of project development) and in response to DES review should be emphasized. Comments concerning DES adequacy must be appropriately addressed and included as part of the EIS record including necessary changes in analysis, text, or project design. In order to accomplish this and other similar efforts, it will be necessary to increase tribal analytical resources on a tribe-by-tribe basis and/or as a CERT function.

- As discussed earlier, litigation may be initiated at two stages in the EIS process: after a Negative Declaration has been filed for projects declared by the federal agency to have no significant impact on the human environment, and parties with a standing interest contend otherwise; or after an FES is filed, and parties with a standing interest contest its adequacy or compliance with procedural requirements. Timely and successful litigation depends heavily on the availability of technical and legal expertise to the tribes.

- Litigation may be initiated on technical or procedural grounds to achieve one of several ends: to gain sufficient time to perform more detailed analysis or organize outside support; to effect a modification of the project from its original plan; to stop completion of the project on grounds that its impacts cannot be modified sufficiently to meet federal requirements (such as a threat to an endangered species or an historic site); or concelvably to delay project construction to an extent that increased costs due to delay will adversely affect overall financlal attractiveness of the venture. 
With an understanding of how the EIS process presented in this section works, Section III examines the adequacy with which Issues important to Indian Nations have been addressed in the preparation of EIS's. 
III. REVIEW OF ISSUES INADEQUATELY ADDRESSED

IN ENVIRONMENTAL IMPACT STATEMENTS

INTRODUCTION

In writing this section, we have assessed specific environmental impact statements (EIS's) and their relationship to energy resource development on Indian lands. In conducting this assessment, we have reviewed the most recent statements that pertain to energy resource development projects on or near Indian reservations, including:

- EIS's on Indian Reservations

- Final (FES)

Crow Ceded Area Coal Lease, Tracts II and III. Westmoreland Resources (FES-76/64)

[Crow Indian Reservation]

Sherwood Urantum Project, Spokane Indlan Reservation (FES-76/45)

Lease of the Ute Mountain Ute Tribal Lands for Uranium Exploration and Possible Mining (FES-75/94)

Proposed Modifications to the Four Corners Power Plant and Navajo Mine (FES-76/36)

Western Gasification Company (WESCO), Coal Gasification Project and Expansion of Navajo Mine by Utah International, Inc., New Mexico (FES-76/2) 
Navajo Indian Irrigation Project, San Juan

County, New Mexico (FES-76/52)

- Draft (DES)

Navajo-Exxon Urantum Development (DES-76/25)

Proposed Expansion of the San Juan Power Plant, New Mexico (DES-76/33) Navajo Reservation]

Water for Energy, Missouri River Reservoirs . - , Pick-Sloan Missour1 Bàsin Program (DES-76/38) [Fort Peck, Fort Berthold, and Cheyenne River Indian Reservations]

- EIS's Near Indian Reservations

- Final (FES)

Second Unit Huntington Canyon Generating Station and $345 \mathrm{KV}$ Transmission Line, Huntington, Utah (FES-75/11) [Uintah and Ouray Reservation]

- Draft (DES)

Proposed Plan of Mining and Reclamation, East Decker and North Extension Mines, Decker Coal Company, Big Horn County, Montana (DES-76/40) [Crow and Northern Cheyenne Indian Reservations]

Each of these EIS's was reviewed for treatment of socio-cultural impacts and summarized in detall. I/ These summaries provided the means to analyze thoroughly the adequacy of coverage of the areas studied and to determine what issues of particular importance to Native Americans either were not adequately addressed or were totally ignored. Identification of the social and cultural impact deficiencies in past environmental statements can have three beneficial effects for Indian Nations:

- Some socioeconomic considerations, that otherwise might be overiooked by a non-Indian analyst during future EIS preparation, will be brought out.

1/

Because of their length, these summaries are not included in this report; however, copies can be made available upon request. 
- Development options that may benefit tribes to a greater or lesser degree over shortand long-term periods may be brought out.

- A more specific and uniform information base will be available for DES review.

The deficiencies in the EIS's were identified on the basis of the comments Included In the "Review and Comment Section" of the Final Environmental Statements (FES's) and from the results of our individual site visits. The following portions of this section present detailed discussions of the social and cultural issues used as variables in determining tribal benefits and costs of mineral development on reservation lands. The first part reviews the comments found in the "Revlew and Comment Section" of the Final Environmental statements, while the second identifies additional tribal criteria necessary to make informed evaluations of possible adverse project impacts on tribal members. The summary provides the reader with an outline (or checklist) of factors that should be considered in an EIS.

TRIBAL CONCERNS INADEQUATELY ADDRESSED IN EIS'S

As discussed in Section II, comments may be submitted by the public or by any local, state, or federal agency either at a public hearing or following circulation and review of a DES. Comments and responses must be Included by the preparing agency in the Final Environmental Statement (FES) and are considered in the approval or nonapproval of the action. The number and substance of comments tend to vary among projects, depending on the magnitude and type of project and the number of people involved. A preliminary review of DES comments in the seven FES's that involve energy resource developments on or near Indian lands was performed to provide an indication of the adequacy of the existing EIS 
analyses and procedures in dealing with the social, economic, and cultural concerns of Indians.

A total of over 200 DES comments were Included in the seven FES's reviewed. Of these, more than 35 criticized the adequacy of the DES in sufficiently identifying the full range of potential soctal, economic, and cultural impacts, or fully exploring the range of available alternatives to mitigate some or all of these adverse impacts. $1 /$

The comments addressed here include those submitted by tribes, agencies affiliated with a tribe, and outside agencles that have commented on the welfare of a tribe (e.g., local planning agencies, U.S. Department of Housing and Urban Development). Comments concerning more routine analyses, not specifically directed at tribal social, economic, or cultural concerns (e.g., U.S. Geological Survey soils analysis comments), are not included.

The areas of concern cited most often in comment letters focused on the following categories and subcategories:

- Social Impacts

Planning refers to compatibility of the proposed project with existing land use, air quality maintenance, and water management plans, and the extent to which additional needs and services (health, housing, fire, police, sanitation, recreation, etc.) can be supplied.

Law Enforcement involves furisdictional issues in regard to criminal and civil matters, and the problem of security in the project area.

Health covers Eribal concerns regarding health hazards related to mining and environmental pollution.

If Each comment regarding the DES was responded to in the FES on an individual basis. Some comments required additional analysis on the part of the lead agency, while others were considered outside the scnpe of the EIS. 
- Economic Impacts

Employment includes assessment of the proposed project's impact on Indian employment, with emphas is on the ratio of Indian to non-Indian hiring, and the use of training programs at all skill levels.

Tribal finances focuses on the short- and longterm financial benefits to tribes under proposed contractual arrangements, and on the need to consider alternative financial schemes.

Market analysis centers around the justification for locating the project at the proposed site in light of existing and potential market constraints (e.g., changes in product demand, transportation, etc.).

- Cultural Impacts

Cultural conflicts may arise from incompatibility among families of new employees attracted to the area and the native population. The preservation of cultural institutions and resources (e.g., tribal customs, historical sites, archeological finds) is also of concern.

Air quality considers the potential adverse health effects of project-generated pollutants and the conflict with some Indian perceptions of air quality-a very high value is placed on clean air by some tribes.

Water quantity and quality focuses on evaluating fully the availability and quality of water for the proposed project in light of existing needs (e.g., residential requirements, cattle raising, agriculture) and supplies.

Reclamation addresses the potential for returning project lands to their natural state after the life of the project. Cultural as well as ecological aspects of reclamation are of major importance.

- Procedural and Other Impacts

EIS input concerns the extent to which Indians are made aware of project development, avenues available for input to DES preparation, and the ability of tribal members to comprehend the impacts described in a DES. 
Legal responsibility refers to possible jurisdictional issues regarding the legal interface among tribes, states, and the federal, government in dealing with Indian lands.

As a result of our site visits to the 22 CERT reservations, additional deficiencies of EIS's were revealed by tribal members in conversation and in tribal publications. These concerns were usually more specific than those found in the "Review and Comment Section" of the EIS's. Most of these issues deal with cultural variables of importance to tribes in making decisions regarding mineral developments. The following list includes those issues raised by at least two tribes. As it is hard to generalize, one must remember that not all the issues identified below are relevant to all tribes, nor all projects:그

- Checkerboard patterns of land ownership on the reservation

- Destruction of the land's surface

- Leaching of minerals into the drinking water

- Water usage

- Deprioritization of water rights issues

- Isolation of profect area

- Urbanization of the reservation

- Loss of culture due to assimilation

- Disruption of wildiffe habitat

- Monttoring of impacts after development

- Internal conflicts within the Department of Interior

- Educational and language barriers

- Health hazards

- Religious beliefs and restrictions.

1/ As noted, this list was compiled from our site visit reports. We are merely reporting on the comments made by tribal members interviewed. 
Since the environmental impact statement is used by federal, state, and local agencies as well as by the general public (including Indian Nations), as a means of assessing the effects development will impose on the environment, some form of benefit-cost analysis is usually used for policymaking and final approval. If EIS's do not adequately cover the social and cultural variables unique to Indian tribes, there is little chance that these benefitcost analyses will be reliable. Environmental, social, and cultural variables (each of which has a value judgment attached to it) are discussed, analyzed, and projected in each EIS. Indians and non-Indians attach different weights to issues based on their own value systems and, consequently, the outcome of the EIS may be distorted, depending upon whose point of view is involved.

In many cases, the environmental and social impacts of minerals development have been downplayed by developers and government agencies, while the potential economic benefits have been emphasized. Under such circumstances, some tribes entered into mineral development agreements quite readily, and it was not until the development was under way that the tribes gained an awareness of ail the repercussions involved. The Four Corners projects on the Navajo Reservation are well-known examples of this phenomenon. While these current projects have positively impacted the affected tribes economically, numerous negative environmental and cultural impacts have caused the affecter tribes to exercise more caution in evaluating the many additional projects that are proposed.

Most tribes are generally not opposed to mineral development if the monetary benefits to the tribe are expected to exceed the tribe's monetary costs, and it is not harmful to the environment or to tribal traditions. If serious negative impacts are expected to occur, tribes must weigh the monetary 
benefit against both the financial and environmental "spillover" costs. The weight attached to environmental costs will vary by project and location, depending both on the severity of the costs (e.g., health effects) and the attitude of the specific tribe toward such qualitative factors as aesthetics. What must be stressed, however, is that it will be difficult to make an adequate assessment of these impacts without sufficient information about the nature of these benefits and costs. EIS's have been the most common means of presenting tribes with the environmental, soclal, and cultural information (e.g., impacts) necessary to evaluate mineral development projects. Therefore, it is important that the EIS explore the 1ssues that tribes consider important in assessing the possible changes that could occur as a result of a particular development project.

Unfortunately, EIS's prepared for Indian-related projects presently do not delve deeply enough into possible social and cultural impacts to discover the true extent and significance of the possible impacts. The principal reasons for this lack of depth are:

- The agencles preparing the EIS are unfamiliar with the extent of social and cultural impacts.

- The data are neither readily avallable nor easily collected, especially for cultural aspects and impacts.

- Unlike the physical impacts, social and cultural impacts are not easily quantifiable.

INFORMATION NEEDED TO ADDRESS TRIBAL ENVIRONMENTAL CONCERNS ADEQUATELY

It is becoming increasingly clear that Indian Nations will

have to assume a greater role in looking after their own interests. This may involve providing government agencles with information about tribal concerns 
needed to assess mineral development. To that end, the following analysis identifies additional tribal concerns agencies should consider in environmental impact statements.

The mafor concerns of most tribes regarding the social and cultural impacts of mineral development fall into the following categories of impacts:

- Air quality

- Water quantity and quality

- Aesthetic quality

- Land use planning

- Education

- Traditional life-styles and culture

- Employment.

While most of the EIS's revlewed for this task gave some consideration to all the above concerns, the level of analysis used to address social and cultural impacts was Inadequate. In addition, the unique economic status of most reservations was generally unrecognized in the impact analysis.

- For some Indian Nations, the environmental impacts are more often than not equated with the social and cultural impacts. The air, water, land, health, and well-being of the people are elements of the "total" environment that have traditionally been considered "one" by many of the tribes and cannot be separated. The "risks" to the air, water, and land can sometimes overrule the economic benefits. Exhibit III-1 indicates the impacts that most EIS's have discussed and, further, lists the additional impacts on Indian society that they have overlooked. A discussion of each category and its respective impacts follows. 
EXHIBIT III-1

SOCIAL AND CULTURAL CONCERNS ADDRESSED AND NOT ADDRESSED

IN ENVIROMMENTAL IMPACT STATEMENTS

\begin{tabular}{|c|c|c|}
\hline Issue & Mentioned & Not Mentioned $\underline{1}$ \\
\hline \multicolumn{3}{|l|}{ Physical Issues } \\
\hline Air Quality & $\begin{array}{l}\text { - Technical analysis of negative air quality resulting } \\
\text { from the project }\end{array}$ & $\begin{array}{l}\text { - Degradation of life due to tribal cultural } \\
\text { bellefs } \\
\text { - Cultural significance of the reservation }\end{array}$ \\
\hline $\begin{array}{l}\text { Water Quality } \\
\text { and Quantity }\end{array}$ & $\begin{array}{l}\text { - Water use requirements } \\
\text { - Impact on services } \\
\text { - Water rights. } \\
\text { - Contamination resulting from the project }\end{array}$ & $\begin{array}{l}\text { - Degradation of life due to tribal cultural } \\
\text { beliefs Involving the use of water } \\
\text { - Change. in recreational patterns in tribal } \\
\text { lands }\end{array}$ \\
\hline $\begin{array}{r}\text { Aesthetic } \\
\text { Quality }\end{array}$ & $\begin{array}{l}\text { - Disruption of the natural setting } \\
\text { - Reduced visibility }\end{array}$ & $\begin{array}{l}\text { - Impact on Indian values tied to the natural } \\
\text { environment } \\
\text { - Change in recreational patterns on tribal } \\
\text { lands }\end{array}$ \\
\hline \multicolumn{3}{|l|}{ Social Issues } \\
\hline $\begin{array}{l}\text { Traditional Life- } \\
\text { Styles ang } \\
\text { Culture } 2\end{array}$ & $\begin{array}{l}\text { - Breakdown in soctal bonds of family and community } \\
\text { Relocation } \\
\text { Loss of culture } \\
\text { Loss of wildlife }\end{array}$ & $\begin{array}{l}\text { - Lack of depth in analysis of cultural and } \\
\text { religious beliefs and traditional life-styles } \\
\text { - Mobility } \\
\text { Traditional hunting and fishing patterns }\end{array}$ \\
\hline $\begin{array}{l}\text { Land Use } \\
\text { Planning }\end{array}$ & $\begin{array}{l}\text { - Need for planning } \\
\text { Use of multipliers } \\
\text { Need for Increased tribal involvement }\end{array}$ & $\begin{array}{l}\text { - Lack of access to adequate planning expertise } \\
\text { Use of incorrect multipliers } \\
\text { - Impacts upon project completion (e.g., closing } \\
\text { of a mine) } \\
\text { - Minority position in regional planning process }\end{array}$ \\
\hline Education & $\begin{array}{l}\text { - Increased enrollment } \\
\text { - Increased need for more school factlities } \\
\text { - Decreased quality }\end{array}$ & $\begin{array}{l}\text { - Indians as minority } \\
\text { Opportunity for advanced education }\end{array}$ \\
\hline $\begin{array}{l}\text { Employment and } \\
\text { Income }\end{array}$ & $\begin{array}{l}\text { - Increased number of jobs } \\
\text { - Increased income } \\
\text { - Increased standard of living } \\
\text { - Avallability of training programs }\end{array}$ & $\begin{array}{l}\text { - Change in economic situation at project end } \\
\text { - Resulting conflict between economic livelihood } \\
\text { and traditional life-style }\end{array}$ \\
\hline
\end{tabular}

$\frac{1}{2}$ Issues expressed during reservation site visits, public hearing testimony, or in DES comment letter.

2/ While several areas are covered In EIS's, none is covered in suffictent depth. Hence, there is overlap between points mentioned and not mentioned in this category. 
Physical Impacts

Social and cultural impacts on the "human environment" are not readily quantifiable and cannot be discussed in terms of specific criteria or standards. Norms for human environmental factors vary among (as wel1 as within) ethnic groups and geographic locations, and they generally reflect the philosophies and needs of the societies from which they evolve. This situation can be contrasted with the fairly uniform criteria and standards that apply to the physical enviroments (e.g., air, water, and noise pollution standards) that cross social and cultural boundaries. There are, however, cultural concerns about air and water quality that are not addressed.

- Alr Quality. Sections In the EIS's concerning air quality quantified the data and discussed them in terms of their negative impact on the environment. However, the attitude some tribes have toward degradation of their environment and the cultural significance of the reservation are generally not addressed.

- The degradation of the air quality on a reservation has cultural impacts on some tribes because traditional tribal beliefs link the people with the environment emotionally, religiously, and aesthetically. In certain cases, the economic gain assoclated with mineral development may create social, cultural, and environmental problems that far outwelgh the benefits. For example, a power plant may cause pollution emissions that would sufficlently degrade the environment so that the productivity of the forests and grazing land is diminished, health problems are increased, and the land is ruined aesthetically (as seen from a cultural standpoint).

- As one example of the above point, the Northern Cheyenne Tribe has written an air quality redesignation report that makes the tribe's opinion on air pollution public. The report mentions that "Air quality degradation could disrupt 
the Tribe's ability to contipye a unique lifestyle we wish to preserve." - The report also states that "after years of warfare, 'relocation,' and continually reduced land base, the Northern Cheyenne were granted the area they occupy today. The reservation is more than an economic source for the tribe. It is a link to a past we have no wish to disown, and it is a medium for continuing the traditions so important to us as a reople." 2

- A distinction to be made regarding Indian land is that it is a vehicle through which tribal history and culture can persevere. The existence of a reservation in an unpolluted environment gives tribes the opportunity to continue traditional life-styles.

- Water Quantity and Quality. Water quantity and water rights are important issues on Indian lands and there are numerous contradictions involved and disputes in progress concerning them. The EIS's generally state the quantity of water that will be necessary to develop the projects. In some cases, the quantity of water needed will have a significant impact on the supply of water to the project area, as well as to the surrounding residential and municipal areas. In addition, EIS's generally cover the issues of water rights and possible contamination resulting from energy-related activities. However, the EIS's do not generally consider the cultural beliefs of tribes as they relate to water quality and quantity or the impacts due to changes in the recreational patterns on the reservation.

- Water quality is significant to many tribes from the perspective of traditional cultural values and deserves the same consideration given to air quality. Several tribes have experienced deteriorating water quality as a result of coal mining (e.g., Crow) or inadequate plugging of oil and gas wells (e.g., Cheyenne River Stoux). As an example, this deterioration of water quality may have negative cultural impacts on traditional tribal rituals involving the use of water. In addition, poor water quality decreases the attractiveness of the reservation as a living environment for tribal members.

1/ Northern Cheyenne Risearch Project, The Northern Cheyenne Air Quality Redesignation Report and Request, Lame Deer, Montana, 1976, p. ili.

2) Ibid. 
- For example, the Cheyenne River Sioux Tribe and the Fort Peck Tribes have experienced negative impacts as the result of energy and water projects. The Sioux Tribe was a victim of a project involving a recently built dam (prior to NEPA) that flooded several hundred acres of their land and destroyed many tribally significant sites, as well as their most fertile agricultural land. The Fort Peck Tribes are concerned about a Canadian dam that will decrease both the quantity and the quality of the water that runs through their reservation.

- Water quality deterioration may also create a negative economic impact by decreasing the fish and wildlife population, thereby decreasing the attractiveness of the reservation for recreational or tribal fishing and decreasing the income derived from fishing licenses.

Aesthetic Quality. The analysis of aesthetic quality in some EIS's is Iimited either to the disruption of the natural setting due to the location of a power plant or to the decreased visibility due to air pollution. There is generally no discussion of the cultural impacts this will have on people who consider their environment an integral part of their culture and Iife-style.

- The aesthetic value of the reservation is of utmost concern to most tribes. The reservation is the basis for many tribal functions and traditions. Thus, any degradation of the reservation's environmental quality represents a serious threat not only to tribal aesthetic sensibilities but to essential tribal activities.

- In some EIS's no mention is made of the possible decrease in tribal revenues from tourism as alternative camping or hunting sites become more attractive to tourists.

\section{Social and Cultural Impacts}

This is the area least understood and least adequately covered in EIS's. It is the most difficult to define, as the cultural attitudes and values of tribal members vary from tribe to tribe as well as within tribes. Nevertheless, it is important that more emphasis be placed on cultural considerations. 
Traditional Life-Styles and Culture. In their analysis of life-styles and culture, most EIS's cover the breakdown in social bonds of the family and community, relocation, and loss of culture and wildlife, but they do not go into sufficient depth in explaining the significance of these effects.

- A change in the traditional social bonds of family and community is generally considered in EIS's to be a phase tribes must go through to achieve a better "standard of living." However, most tribes may, not want to forego their traditional culture and assimilate to the mainsteam American way of 1ife. What most tribes appear to be seeking is economic development of a nature that allows achievement of selfsufficiency within the context of traditional culture.

- A very high monetary rate of return may be required to undertake a project where environmental degradation has a high probability of occurrence. In some cases religious values have eliminated certain areas from development. For example, on the Hopi Reservation, clans and religlous societies lay claim to tracts of land as shrines and for other religious purposes. Among the Pueblo Indians, various religious groups within the tribe consider certain lands to be shrines around which no mineral development is to occur. In addition to the religlous shrines, other landmarks on the reservation (former fortress sites or ruins of ancestral villages) have historical significance to the whole tribe. In the case of village ruins, blasting within a certain range could damage fragile structures. In order to assure that no group's religious shrines are destroyed, one tribe had a land use map prepared that delineates all such significant lands. Preparation of future EIS's should require impact assessments relative to each shrine site located near a proposed mineral development site.

- Mobility is another cultural matter that needs consideration. Generally, tribal members are not a mobile people in the sense of frequently uprooting their families and moving to a new locale due to development on the1r land. Most tribes derive a strong sense of belonging from the land that their ancestors occupied. The tribal land is a bonding feature of Indian culture that: enables tribes to function traditionally as a unit. This idea contributes to a disinclination for development that will permanently mar their land and require them to move to a new area. 
- Relocation is often a result of a development project. EIS's state that relocation will necessarily cause a change in life-style as if this were an expected repercussion of energy and economic development. Most tribal members in agriculture or ranching enterprises consider these land-related activities to be both businesses and iffe-styles. Relocation often means a change in occupation or even unemployment for the people relocated because there is rarely enough grazing land on which to relocate them. Because ranching and farming are considered to be 1ife-styles, there is a distinction to be made between the selling out of one's business as opposed to one's Iife-style, and this distinction is not made in EIS's.

- A loss of wildlife on the reservations due to increased energy development activities has altered the traditional hunting and fishing patterns on the reservations. EIS's should consider the project's impact on the open season hunting status of most reservations for the tribal members and the income that is derived from hunting permits.

- Land Use Planning. Land use planning is the most commonly mentioned measure suggested to mitigate adverse impacts. Most EIS's stress the need for adequate planning, the estimation of employment and income multipliers and measures of fiscal ("boom town") impacts, and the need for tribal involvement in the planning process. However, not all tribes have access to the adequate planning expertise, typical multipliers cannot be used, and tribal involvement in the planning process is not always a solution to making tribal concerns public. In addition, the EIS's do not address the impacts that will occur at the project's end (e.g., reclamation, sudden decline in employment and income, and negative fiscal impacts).

- EIS's nearly always stress the necessity for planning but fail to acknowledge that access to planning expertise necessary for largescale development may not be available to all tribes. Therefore, some tribes may find it difficult to mitigate many adverse effects through the preparation of comprehensive land use plans, passage of zoning ordinances, and so forth. 
- A typical rural multiplier $1 /$ cannot always be used in projecting population and employment figures on reservations because the towns on most reservations are usually not the trade centers for the reservations. The larger cities ( 40 or 50 miles away) generally handle all the commercial business. As a result, the majority of increased service jobs will not be located on the reservation and therefore probably would not benefit the tribe.

- Impacts on public services and facilities may occur twice as a result of development. The first impact will occur at the time the project begins, when a large number of workers inundate the area. The second impact will occur when the project winds down and ends. There is 1ittle consideration given to the impacts that will occur at this second stage. The communities will be placed in a dilemma because they must choose whether to sacrifice services during the project period and suffer the consequences that overutilization of public facilities and utilities will create, or to extend these facilities and utilities, which would result either in underutilization when the project ends, or in providing the incentive for further development in the future.

- Involvement in the regional planning process is not always a solution to the problem of making tribal concerns public. Tribal representatives are typically in a minority position on planning bodies, causing their views to be given insufficient weight in planning decisions.

- Education. The influx of population to a reservation or the area surrounding it will increase the enrollment in the schools, Most EIS's only consider the impact this increased enrollment will have on the facilities themselves. There is no consideration given to the fact that this might aggravate the problems that Indian children face as minorities in their schools.

1/ A multiplier of 1.6 (16 induced jobs for every 10 direct jobs) for mining activities located in rural areas is considered to be a typical rural multiplier. This estimate is based on the assumption that most service activities in rural areas utilize excess labor and can expand service without increasing the number of employees. 
Some EIS's state that an increased enrollment is expected to cause a decrease in the quality of education. If the quality of education deteriorates at the elementary and high school levels, Indian children will not have the skills needed to pursue higher education.

- Employment. The EIS's address increased employment and income, better standards of living, and training programs as being the beneficlal attributes of development projects. However, there is no consideration of the change in the economic situation at the project's end nor the resulting changes in life-style.

- Changes in the labor force particlpation rate may be twofold. As noted earlier, there will be an impact at the beginning of the project and another at the end. The beginning will bring jobs and income to the area, and training will enhance the opportunities of the employees. When the project winds down and is completed, the trained employees might find that their particular expertise is obsolete on the reservation. This may result in unemployment or transience. Since mobility is not prevalent on the reservation, the pressure to follow the job market could result in greater personal conflict between one's job and one's culture.

SUMMARY CHECKLIST

Our review of the comments from both the FES's and our site visits has brought out the fact that the concerns raised by individuals during our site visits were more extensive than those found in the FES's. These areas of concern may be summarized as follows: 
Environmental

Air Quality

Water Quantity and Quality

Reclamation

Health

\author{
Air Quality \\ Water Quality (leaching) \\ Reclamation \\ Health Hazards \\ Deprioritizing of Water-Rights \\ Issues and Water Usage \\ Underestimation of Impact Area \\ Size \\ Destruction of Land Surface \\ Monitoring of Impacts \\ Disruption of Wildlife Habitat
}

Social and Cultural

Planning

Planning

Law Enforcement

Employment

Tribal Finances

Market Analysis

Culture

Legal Responsibility

\author{
Increased Crime \\ Employment \\ Tribal Finances \\ Market Analysis of Minerals \\ Extent of Culture Loss \\ Jurisdictional Problems \\ Relocation \\ Checkerboard Land Ownership \\ Urbanization \\ Conflicts of Interest within DOI \\ Educational and Language Barriers \\ Religfous Beliefs
}

The comments from the site visits are a source of information that the EIS preparers should take into consideration in future analyses of socio-cultural issues. Our review of the EIS's revealed that these issues are addressed oniy superficially as impacts on Indian tribes. The CEQ guidelines for the preparation of environmental impact statements have not resulted in analyses that go into sufficient detall for the concerns of Indian Nations. Exhibit III-1 showed which Impacts were generally addressed in the EIS's we reviewed and which were not. The exhibit indicates that the preparer's interpretation of "social and cultural impacts" may differ from that of the Indian tribes'. 
The soctoeconomic and cultural topics discussed in an EIS should reflect the fact that an Indian Nation is an ethnic as well as a political entity. As a separate entity, many Indian tribes experience levels of employment, education, and standards of living that are well below the national average and, therefore, the sensitivity of Indian groups to economic, physical, and cultural impacts may be greater than for other population groups in the United States. The Inherent difficulty of quantifying and presenting socioeconomic and cultural characteristics may result in a serious understatement of potential impacts. Impacts on a tribe should be assessed from the perspective of that tribe, not solely from the perspective of a non-Indian entity.

Considering the number of environmental statements available and the amount of information contained in them, a checklist is helpful in determining what elements are not comprehensively addressed in Indian-related EIS's. of course, some potential impacts on the environment are project-specific and do not need to be discussed in every environmental statement. For example, potential impacts on radioactivity would certainly be discussed in a uranium mine development project, but they would not be a consideration in a natural gas well development project. Exhibit III-2 ${ }^{1 /}$ provides a detailed checklist to be used when reviewing an EIS. This will assist the reviewer in quickly determining whether a topic was addressed (adequately or inadequately) or not addressed at a11. The exhibit is based on the typical organization used by the lead agencies in preparing an EIS.

1/ Because of its length, this exhibit is located at the end of this section. 
The information required by $C E Q$ is:

1. Description of the Proposal

2. Existing Environment

a. Physical
b. Social

3. Environmental Impacts

a. Physical

b. Socioeconomic

4. Mitigating Measures

5. Unavoidable Adverse Environmental Effects

6. Relationship of Short-Term Uses to Maintenance of Long-Term Environmental Products

7. Irreversible and Irretrievable Commitment of Resources

8. Alternatives to Proposed Action

9. Consultation and Coordination.

The details within these general categorles are based primarily on the table of contents of the Crow-Westmoreland EIS. 1 / This EIS was singled out because we felt it was organized the most systematically and included the most detail. In addition to the issues found in this EIS, the detailed topics include concerns identified during our site visits.

Since each tribe has its own concerns and tribal customs vary among tribes, the issues and deficiencles may vary. However, this checklist should provide an adequate base from which a reviewer can analyze an EIS.

1/ This EIS was prepared by the Billings Area Office of the BIA. 
EXHIBIT III-2

ENVIRONMENTAL IMPACT STATEMENT CHECKLIST

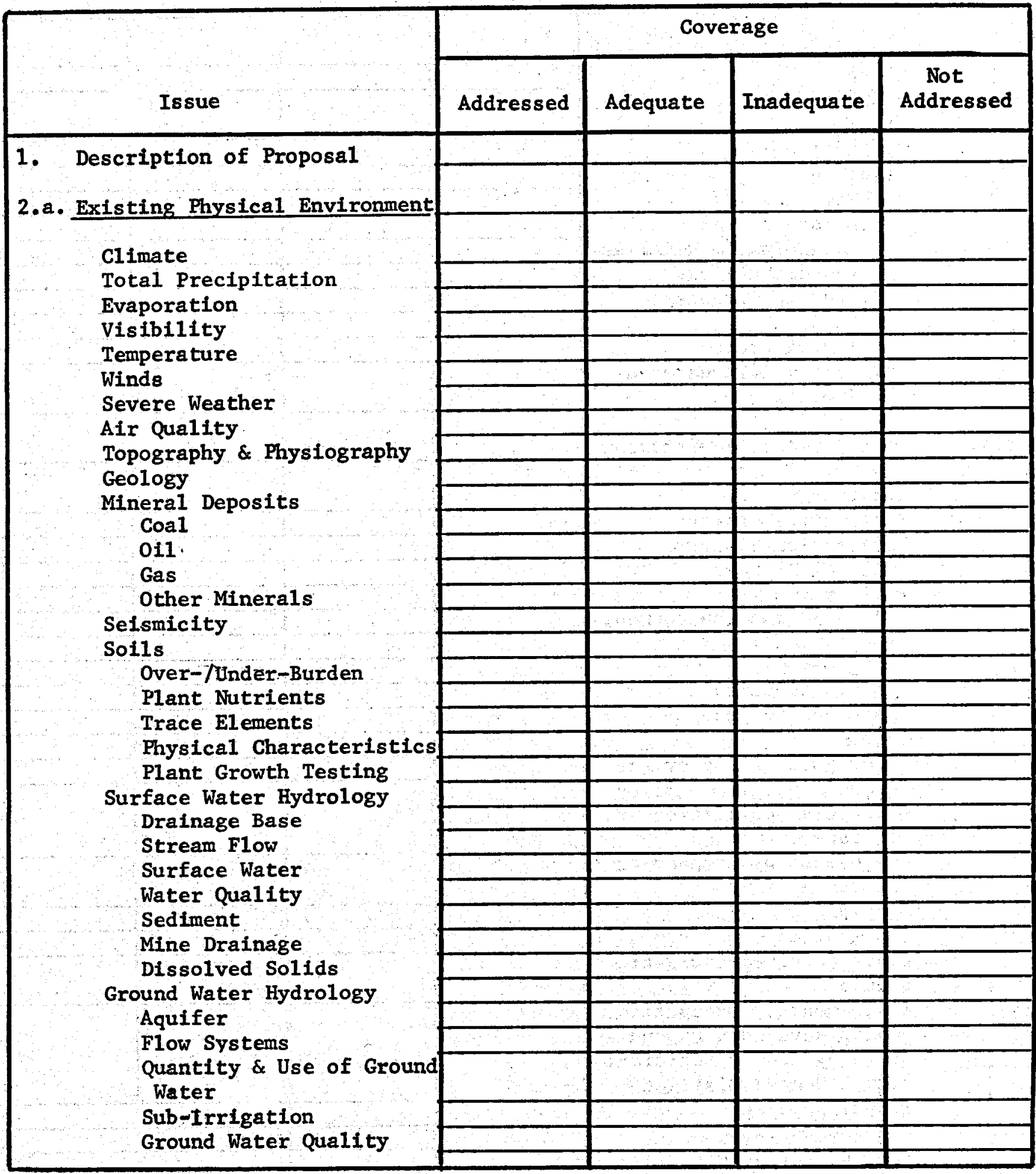


EXHIBIT III-2 (Cont.)

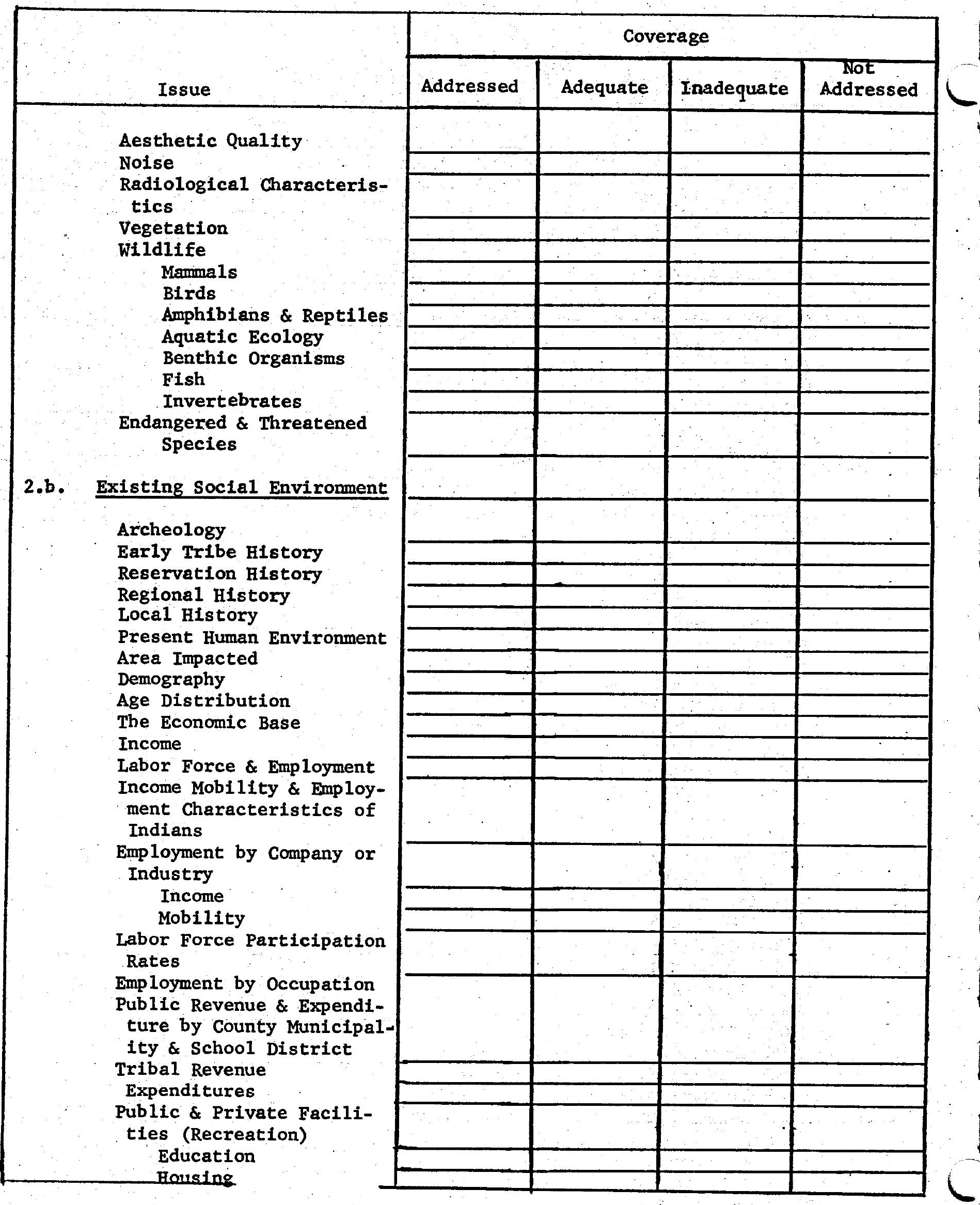


EXHIBIT III-2 (Cont.)

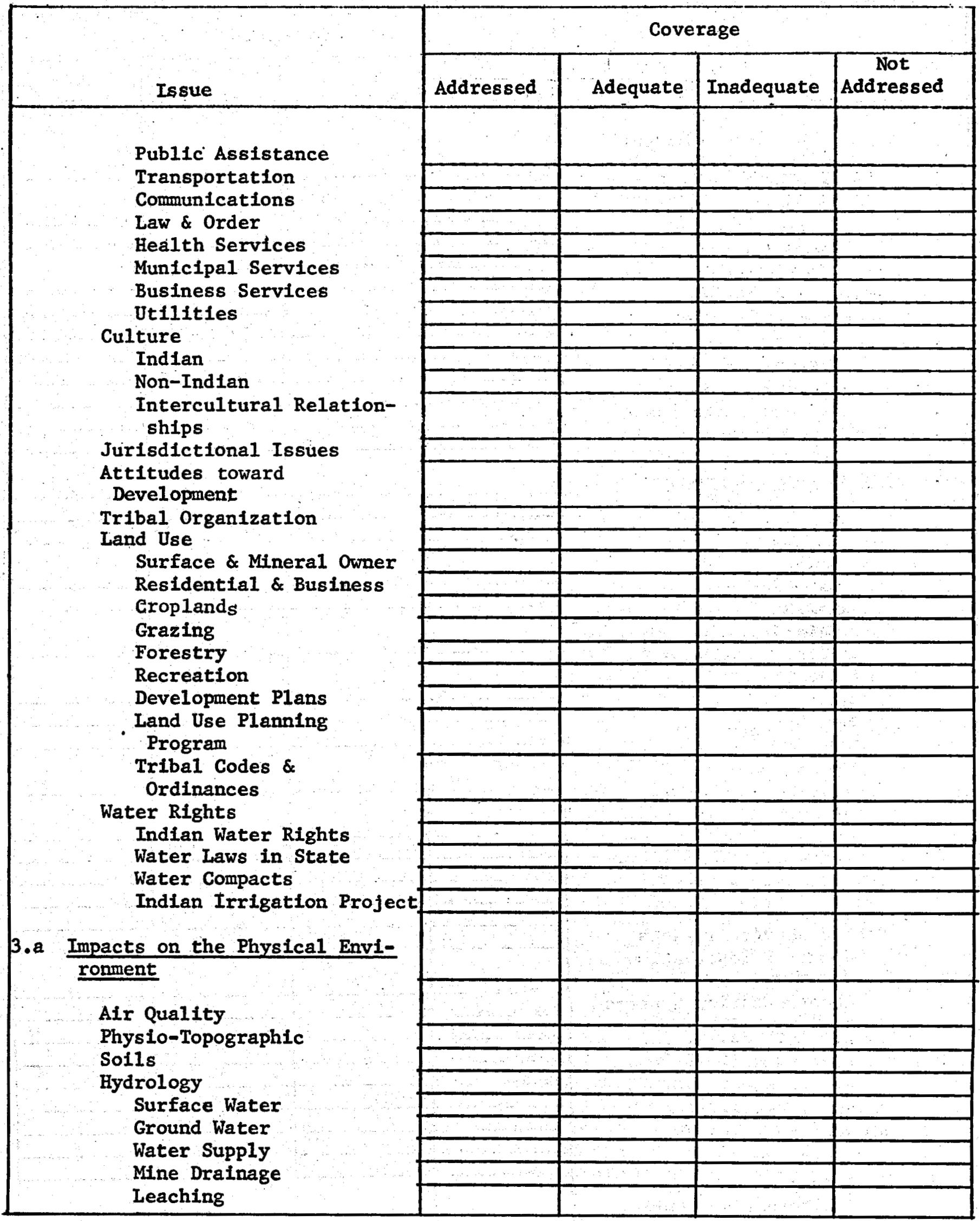


EXHIBIT III-2 (Cont.)

\begin{tabular}{|c|c|c|c|c|}
\hline \multirow{2}{*}{ Issue } & \multicolumn{4}{|c|}{ Coverage } \\
\hline & Addressed & Adequate & Inadequate & $\begin{array}{c}\text { Not } \\
\text { Addressed }\end{array}$ \\
\hline \multirow{37}{*}{ 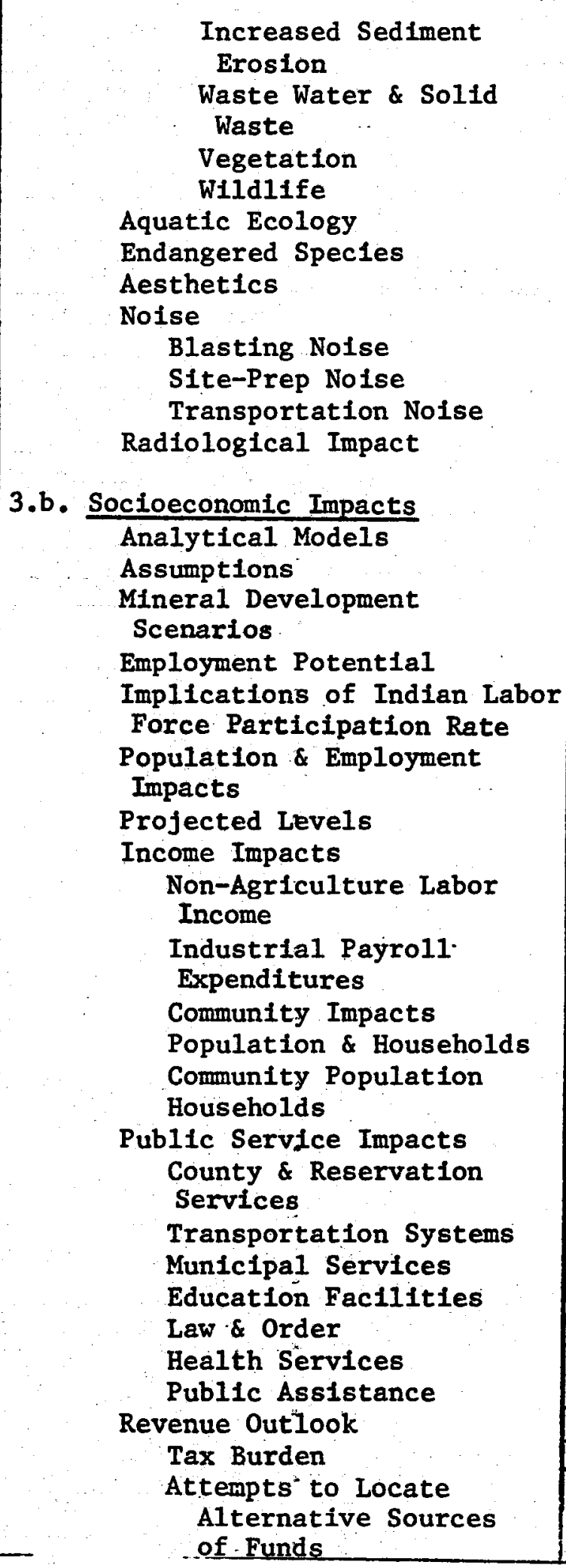 } & & & & \\
\hline & & & & \\
\hline & & & & \\
\hline & & & & \\
\hline & & & & \\
\hline & & & & \\
\hline & & & & \\
\hline & & & & \\
\hline & & & & \\
\hline & & & & \\
\hline & & & & \\
\hline & & & & \\
\hline & & & & \\
\hline & & & & \\
\hline & & & & \\
\hline & & & & \\
\hline & & & & \\
\hline & & & & \\
\hline & & & & \\
\hline & & & & \\
\hline & & & & \\
\hline & & & & \\
\hline & & & & \\
\hline & & & & \\
\hline & & & & \\
\hline & & & & \\
\hline & & & & \\
\hline & & & & \\
\hline & & & & \\
\hline & & & & \\
\hline & & & & \\
\hline & & & & \\
\hline & & & & \\
\hline & & & & \\
\hline & & & & \\
\hline & & & & \\
\hline & & & & \\
\hline
\end{tabular}




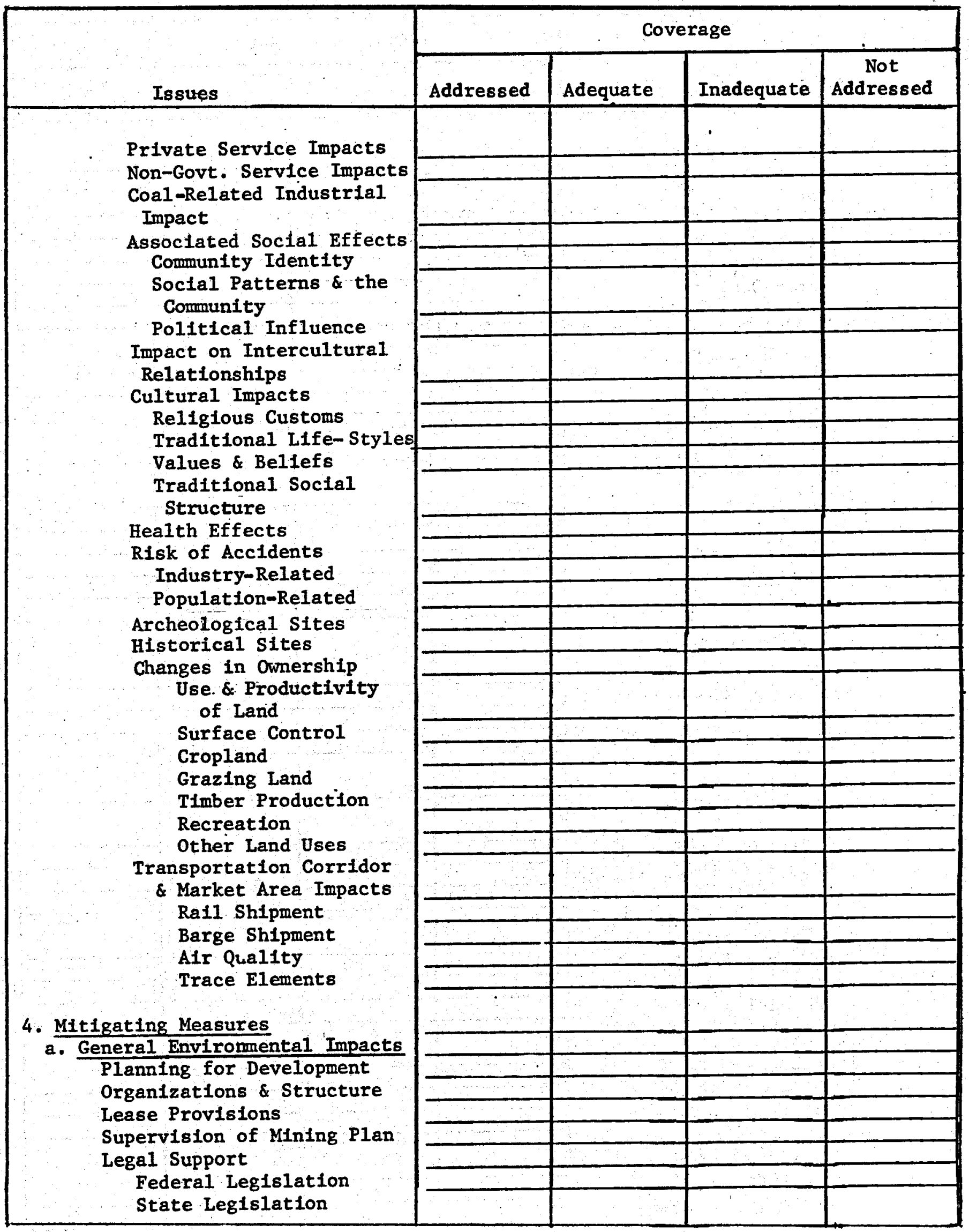




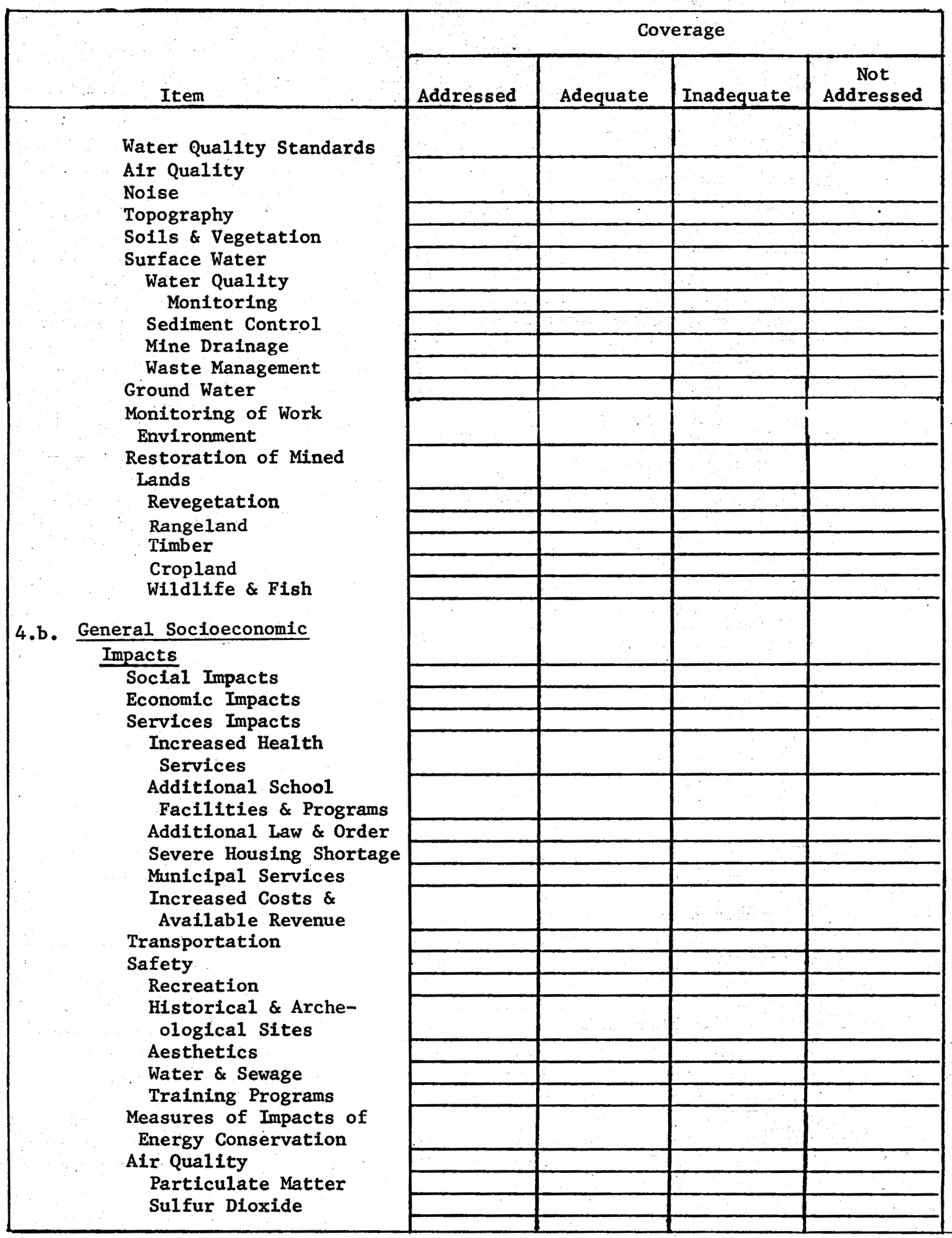




\begin{tabular}{|c|c|c|c|c|}
\hline \multirow[b]{2}{*}{ Issue } & \multicolumn{4}{|c|}{ Coverage } \\
\hline & Addressed & Adequate & Inadequate & $\begin{array}{c}\text { Not } \\
\text { Addressed }\end{array}$ \\
\hline Nitrogen Compounds & & & & \\
\hline Disposal of Solid Waste & & & & \\
\hline Water Resources & & & & \\
\hline Quantity & 三 & & & \\
\hline Quality & & & & \\
\hline Surface Water & & & & \\
\hline 5. Unavoidable Adverse Environ- & & & & \\
\hline Air Quality & & & & \\
\hline Economic Geology & & & & \\
\hline Physlographic \& Topographic & & & & \\
\hline $\begin{array}{l}\text { Land Use \& Productivity } \\
\text { Land }\end{array}$ & & & & \\
\hline Surface Water & & & & \\
\hline Ground Water & & & & \\
\hline Water Quality & & & & \\
\hline Vegetation & & & & \\
\hline Fish \& Wildlife & & & & \\
\hline Aesthet1cs & & & & \\
\hline $\begin{array}{l}\text { Historical \& Archeological } \\
\text { Sites }\end{array}$ & & & & \\
\hline Nolse & & & & \\
\hline Social Impacts & & & & \\
\hline $\begin{array}{l}\text { Services Impacts } \\
\text { Recreation }\end{array}$ & & & & \\
\hline Accidents & & & & \\
\hline Transportation & & & & \\
\hline Radiation & & & & \\
\hline 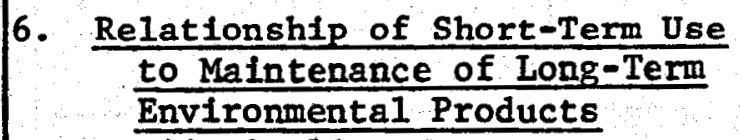 & & & & \\
\hline Air Quality & & & & \\
\hline Mineral Resources & & & & \\
\hline Water Resources & & & & \\
\hline Land Resources Use & & & & \\
\hline $\begin{array}{l}\text { Fish \& Wildilie } \\
\text { Socloeconomic Effects }\end{array}$ & & & 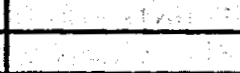 & \\
\hline Cultural Effects & & & & \\
\hline Energy & & & & \\
\hline $\begin{array}{l}\text { Historic-Archeological } \\
\text { Sites }\end{array}$ & & & & - \\
\hline Recreation & & & & \\
\hline Aesthetic Quality & & & & \\
\hline 7. Irreversible \& Irretrievable & & & & \\
\hline
\end{tabular}


EXHIBIT III-2 (Cont.)

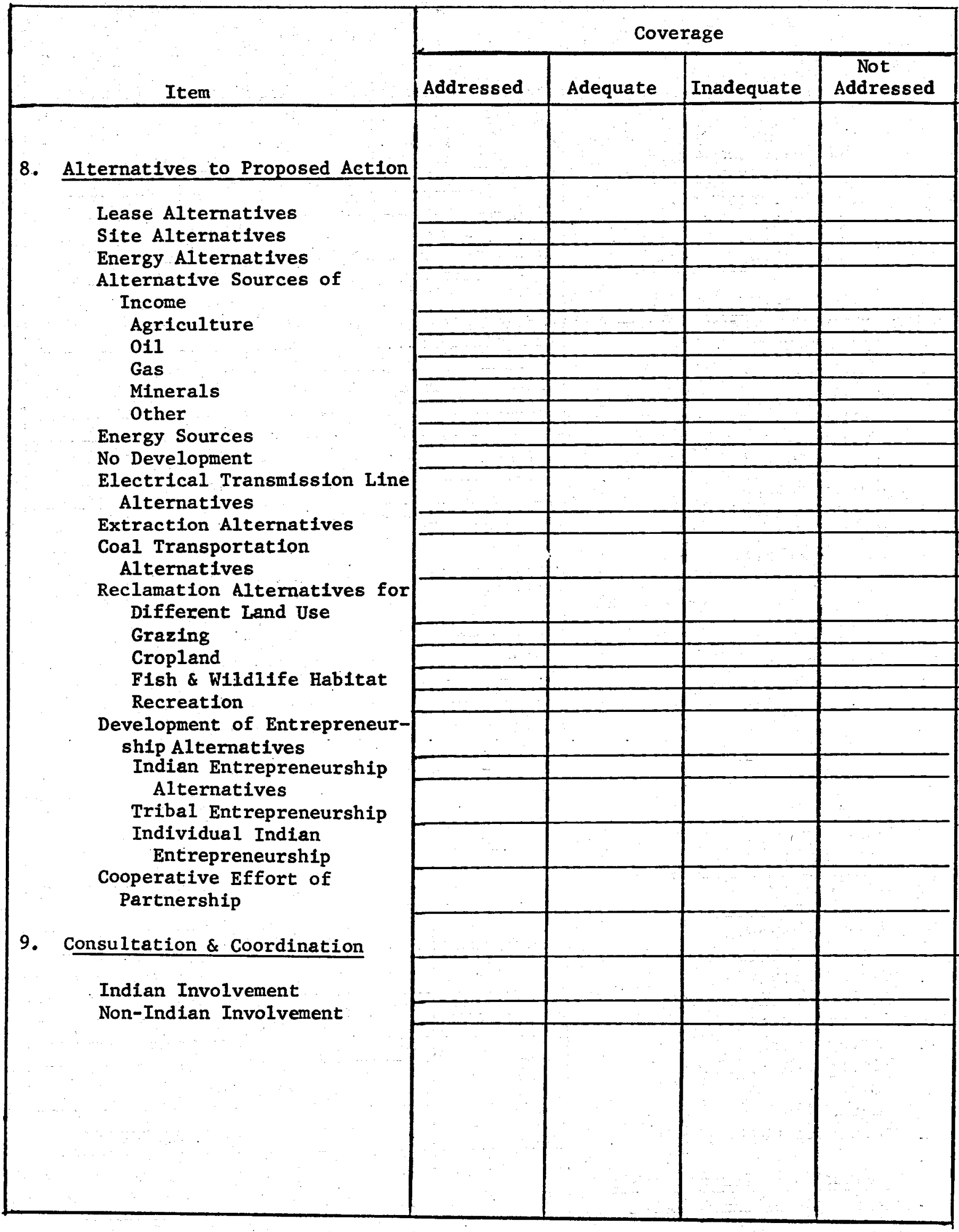


IV. LAWS AND REGULATIONS PERTAINING TO ENERGY

OPERATIONS ON INDIAN LANDS

INTRODUCTION

During the site visits to the 22 CERT members, the tribal

officials and BIA staff identified major environmental concerns and issues (other than those raised in Sections II and III of this volume) regarding Implementation of the National Environmental Policy Act (NEPA). These concerns often are in response to difficulties actually encountered with the operational aspects of past or current projects: unanticipated impacts on health and the environment; insufficient operating standards and guidelines; and/or poorly enforced environmental controls. Two basic issues emerged from these comments: (1) Do existing environmental controls provide enough protection to enable a tribe to develop its resources given its environmental goals? and (2) Should the tribes assert greater oversight and control over energy projects by adopting and enforcing tribal environmental regulations? Before a tribe answers either question, it is necessary to account for the environmental controls that already exist without additional tribal regulation and/or expenditures. The purpose of this section is to assist the tribes that are welghing these benefits and costs by documenting the environmental protection provided by existing laws; highlighting issues and problems that have been encountered in the Implementation of those regulations; and identifying tribal options to strengthen tribal control. 
This section presents three sets of materials needed to support such an assessment. The first subsection documents the federal environmental laws that apply to resource development on tribal lands. This catalog of regulations sets forth the basic provisions of existing environmental controls. The second subsection discusses problems and issues that have arisen with regard to the actual implementation of existing environmental laws. This material may alert the tribes to the limitations of the existing environmental mechanisms. The final subsection describes basic features of tribal initiatives to impose environmental controls on energy developments.

OVERVIEW OF MAJOR FEDERAL ENVIRONMENTAL LAWS AND REGULATIONS THAT AFFECT ENERGY DEVELOPMENT ON INDIAN LANDS

Together with NEPA, environmental laws that control project operations may create the necessary balance between a tribe's development goals and its environmental policies. Typically, these protection measures stem from one of the following types of environmental statutes:

- Laws of "general applicability" 1 / that are intended to protect public health and safety. These statutes require all developments in the nation--including those on tribal lands-to comply with standards needed to protect a particular public resource, such as clean air, clean water, and safe drinking water.

- Laws of "general applicability" that are designed to protect worker health and safety, e.g., the Occupational Safety and Health Act and the laws implemented by the Mining Enforcement and Safety Administration.

- Laws specifically designed to fulfill the government's "trust" responsibilities to the trites for management of tribal lands and to

1'. Laws of "general applicability" are those that apply to all persons, including Indians and Indian lands. FPC v. Tuscarora Indian Nation, 32 U.S. 99, 116 (1960). 
the public for management of federal lands. Such laws as the 1920 Minerals Act and subsequent "Memoranda of Understanding" between the Bureau of Indian Affairs (BIA) and the U.S. Geological Survey have delegated leasing decisions (e.g., when and where to lease) to the BIA and the tribes and the technical and enforcement responsibilities to USGS. To implement their respective responsibllities under these trust acts, the BIA 1ssues regulations in Title 25 of the Code of Federa1 Regulations (CFR); USGS in Title 30 of the CFR.

The purpose of this subsection is to provide the tribes and/or operators with an index of the federal environmental laws that currently offer protection against the impacts of o1l, natural gas, coal, uranium, and other energy projects on Indian 1ands. A glossary of terms that define the acronyms that will be used frequently is presented in Exhibit IV-1. Exhibits IV-2 through IV-6 identify the major federal laws that govern energy development, their citation in the Code of Federal Regulations (CFR), the federal agency responsible for Implementation, and the purpose of such provistons as "planning" or control of "operations" (e.g., exploration, extraction, conversion, transportation). The supporting text describes the key provisions of the regulations and indicates how they are enforced on tribal lands. Exhibits IV-2 through IV-6 also reference where a description of applicable regulations may be found in the text of this report. 
Exhibit IV-1

GLOSSARY OF TERMS

Agency

BIA Bureau of Indian Affairs, Department of the Interior

BLM Bureau of Land Management, Department of the Interior

CERT Council of Energy Resource Tribes

CEQ Council on Environmental Quality

EPA Environmental Protection Agency

USGS U.S. Geological Survey, Department of the Interior

HUD Department of Housing and Urban Development

MESA Mining Enforcement and Safety Administration, Department of Labor

NRC Nuclear Regulatory Commission

OSHA Occupational Safety and Health Administration, Department of Labor

\section{Statutes}

AEA

Atomic Energy Act of 1954

CFR

Code of Federal Regulations

FWPCA Federal Water Pollution Control Act Amendments of 1972

NEPA National Environmental Policy Act of 1969

PL 00-00 Public Law (Citation)

RCRA Resource Conservation and Recovery Act of 1976

SDWA Safe Drinking Water Act of 1974

SMCRA Surface Mining Control and Reclamation Act of 1977

SWDA Solid Waste Disposal Act 


\section{EXHIBIT IV-1 (Cont.)}

Programs

208

State and Areawide Water Quality Planning, Pursuant to Title 208 of the FWPCA

701 : Comprehensive Planning Grants Pursuant to Title 701 of the 1954 Housing Act

AQCR Air Quality Control Region

AQMA Alr Quality Maintenance Areas, Designated for Air Quality Planning under Clean Air Act Regulations

EIS Environmental Impact Statement

NPDES National Pollution Discharge Elimination System (Water Quality)

PSD Prevention of Significant Deterioration (Air Quality)

SIP State Implementation Plans for Air Quality

SPCC Spill Prevention Control and Countermeasure Plans Under the 011 and Hazardous Substance Regulations (Water Quality) 
EXHIBIT IV-2

MAJOR FEDERAL ENVIRONMENTAL LAWS AND REGULATIONS AFFECTING OIL AND GAS DEVELOPMENT

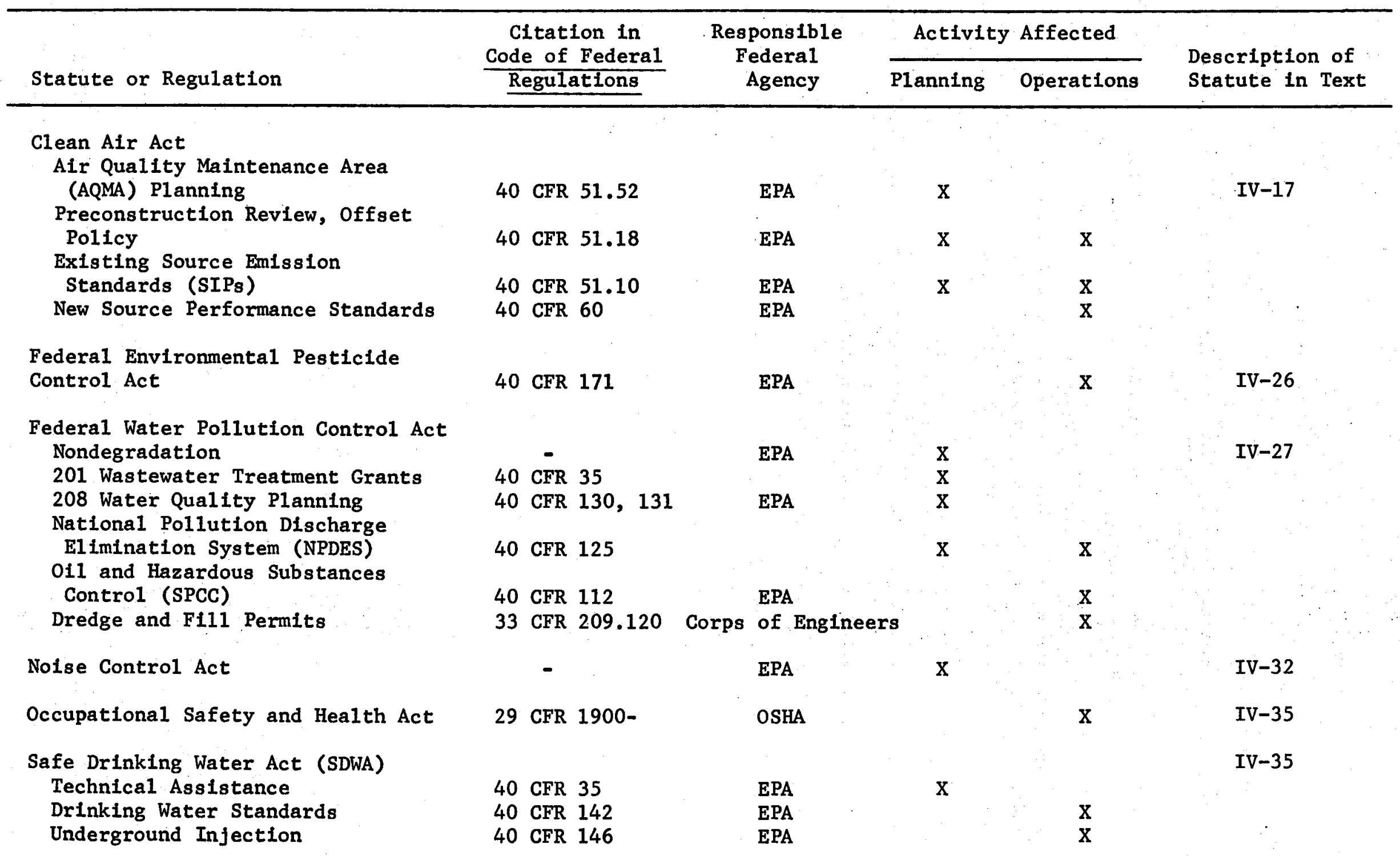


EXHIBIT IV-2 (Cont.)

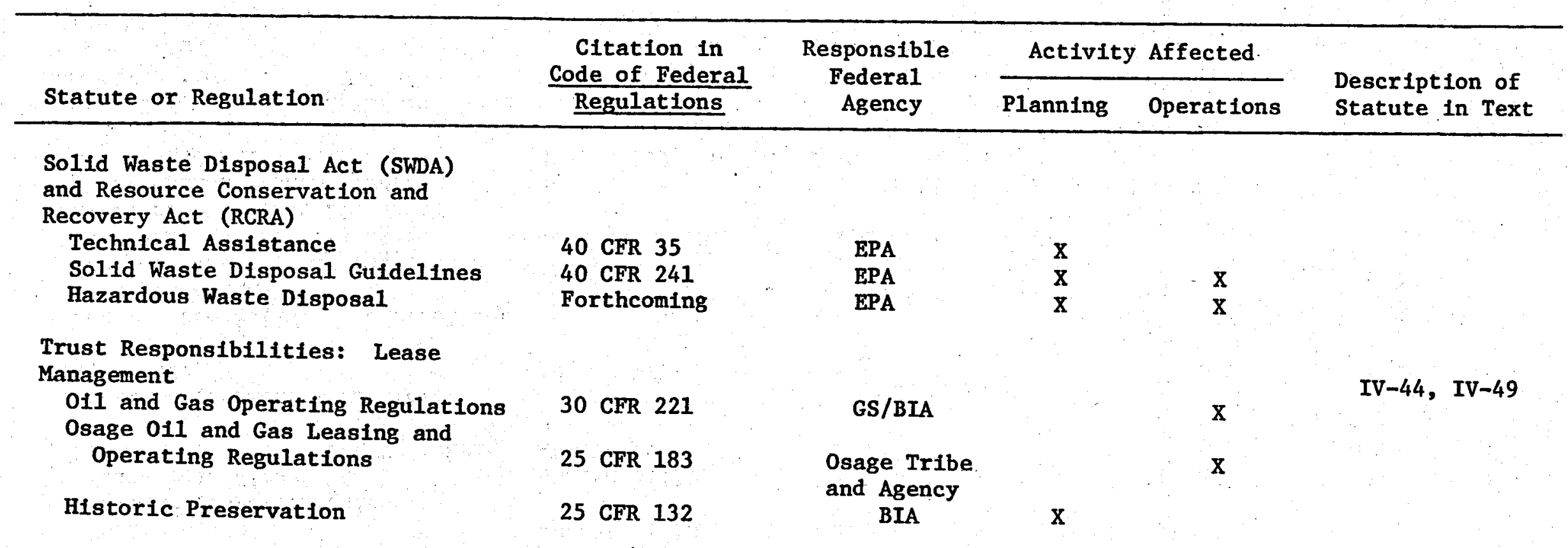


EXHIBIT IV-3

MAJOR FEDERAL ENVIRONMENTAL LAWS AND REGULATIONS AFFECTING COAL DEVELOPMENT

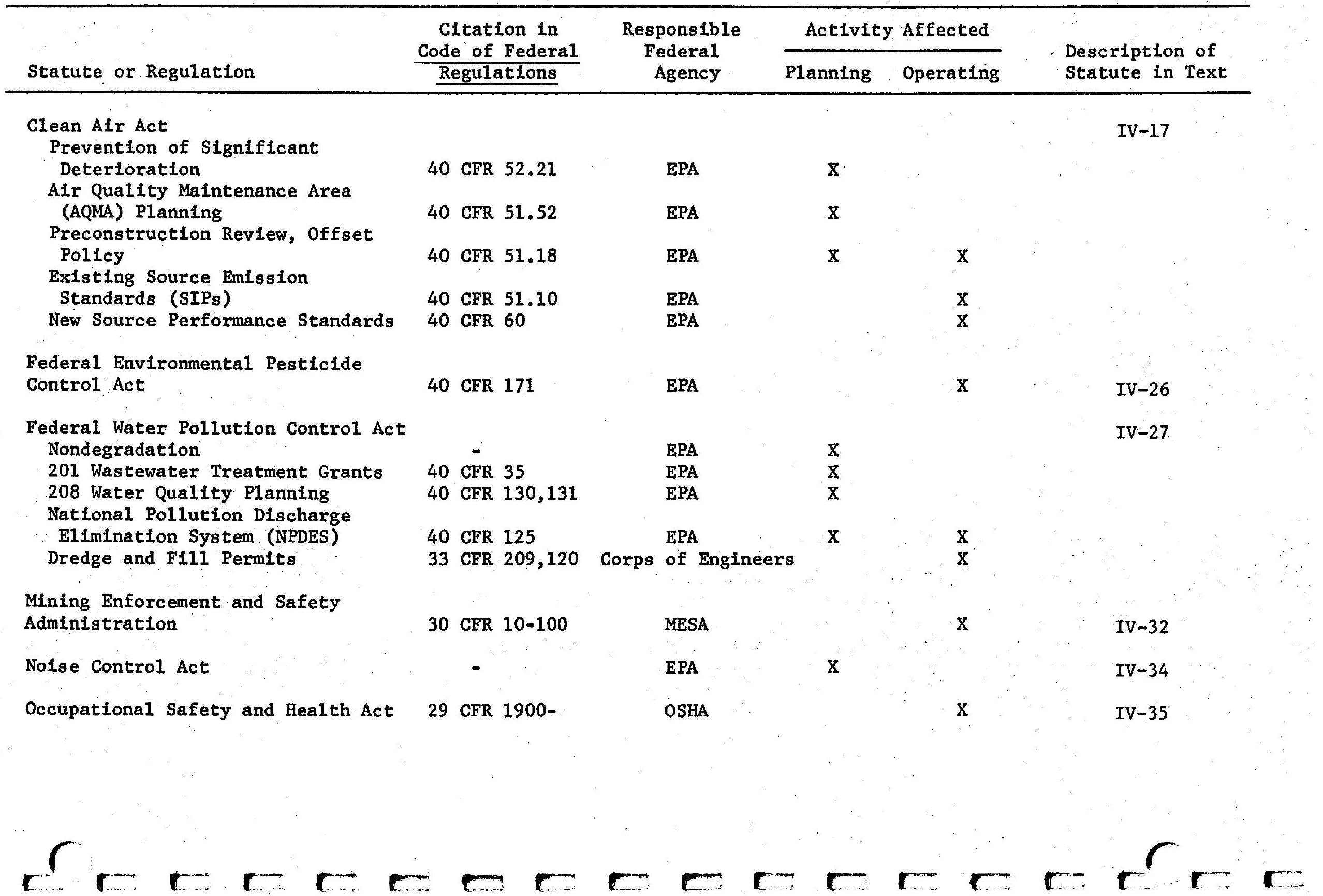


EXHIBIT IV-3 (Cont.)

\begin{tabular}{|c|c|c|c|c|c|}
\hline \multirow[b]{2}{*}{ Statute or Regulation } & \multirow{2}{*}{$\begin{array}{c}\text { Citation in } \\
\text { Code of Federal } \\
\text { Regulations }\end{array}$} & \multirow{2}{*}{$\begin{array}{c}\text { Responsible } \\
\text { Federal } \\
\text { Agency }\end{array}$} & \multicolumn{2}{|c|}{ Activity Affected } & \multirow{2}{*}{$\begin{array}{l}\text { Description of } \\
\text { Statute in Text }\end{array}$} \\
\hline & & & Planning & Operations & \\
\hline $\begin{array}{l}\text { Safe Drinking Water Act (SDWA) } \\
\text { Technical Assistance } \\
\text { Drinking Water Standards } \\
\text { Underground Injection }\end{array}$ & $\begin{array}{lll}40 & \text { CFR } & 35 \\
40 & \text { CFR } & 142 \\
40 & \text { CFR } & 146\end{array}$ & $\begin{array}{l}\text { EPA } \\
\text { EPA } \\
\text { EPA }\end{array}$ & $\mathrm{x}$ & $\begin{array}{l}\mathrm{X} \\
\mathrm{X}\end{array}$ & IV-35 \\
\hline $\begin{array}{l}\text { Solid Waste Disposal Act (SWDA) } \\
\text { and Resource Conservation and } \\
\text { Recovery Act (RCRA) } \\
\text { Technical Assistance } \\
\text { Solid Waste Disposal Guidelines } \\
\text { Hazardous Waste Disposal }\end{array}$ & $\begin{array}{l}40 \text { CFR } 35 \\
40 \text { CFR } 241 \\
\text { Forthcoming }\end{array}$ & $\begin{array}{l}\text { EPA } \\
\text { EPA } \\
\text { EPA }\end{array}$ & $\begin{array}{l}x \\
x\end{array}$ & $\begin{array}{l}\mathrm{x} \\
\mathrm{X}\end{array}$ & IV -38 \\
\hline $\begin{array}{l}\text { Surface Mining Control and } \\
\text { Reclamation Act }\end{array}$ & 25 CFR 177 & DOI & $\mathbf{X}$ & $\mathrm{X}$ & $I V-40$ \\
\hline $\begin{array}{l}\text { Trust Responsibilities: Lease } \\
\text { Management } \\
\text { Exploration, Mining, and } \\
\text { Reclamation Policy } \\
\text { Historic Preservation }\end{array}$ & $\begin{array}{ll}25 & \text { CFR } 177 \\
25 & \text { CFR } 132\end{array}$ & $\begin{array}{c}\text { BIA/GS } \\
\text { BIA }\end{array}$ & $\mathrm{x}$ & $\mathrm{X}$ & $\mathrm{IV}-44, \mathrm{IV}-4$ \\
\hline
\end{tabular}


MAJOR FEDERAL ENVIRONMENTAL LAWS AND REGULATIONS AFFECTING URANIUM DEVELOPMENT

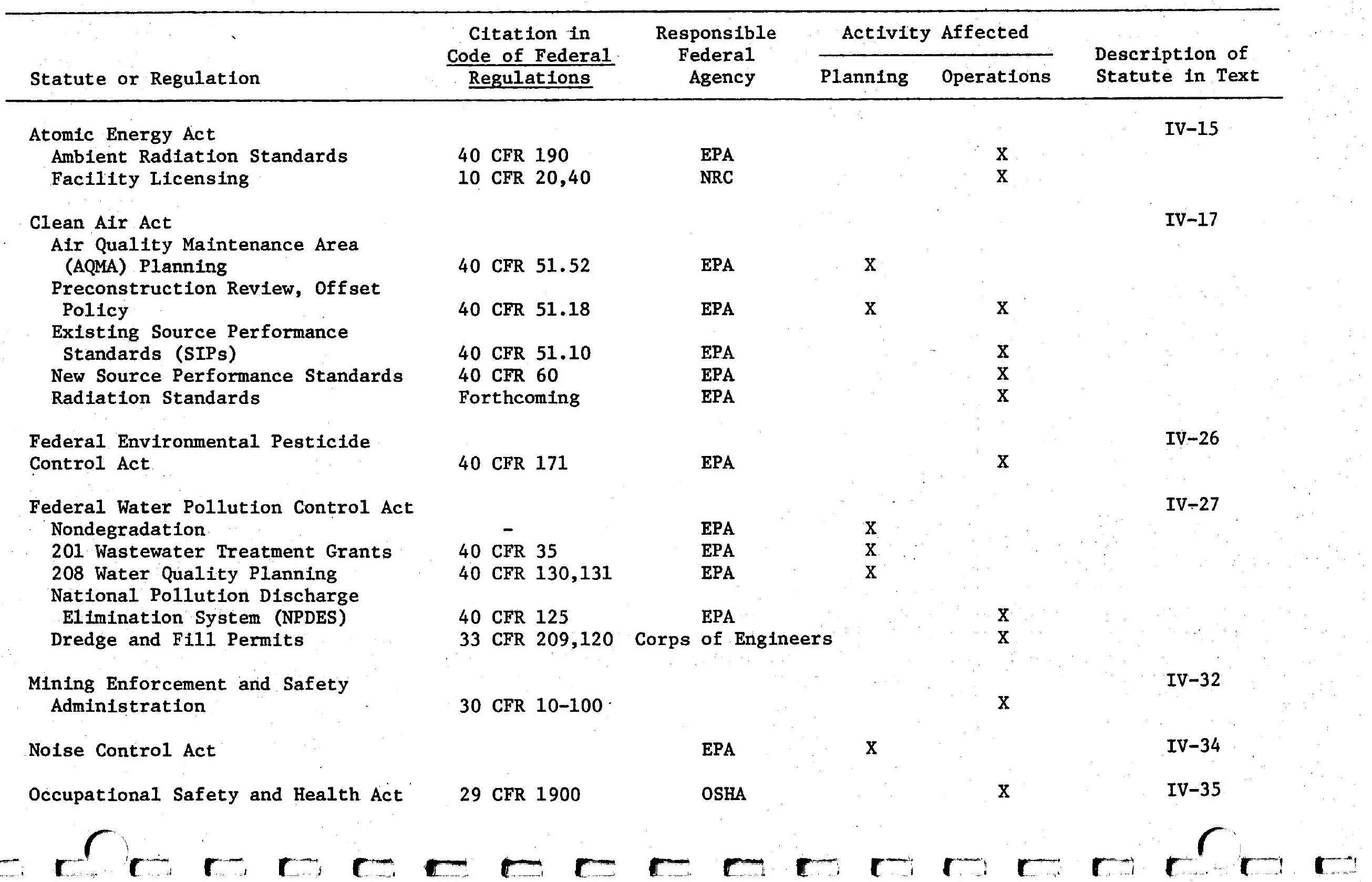




\section{EXHIBIT IV-4 (Cont.)}

\begin{tabular}{|c|c|c|c|c|c|}
\hline \multirow[b]{2}{*}{ Statute or Regulation } & \multirow{2}{*}{$\begin{array}{l}\text { Citation in } \\
\text { Code of Federal } \\
\underline{\text { Regulations }}\end{array}$} & \multirow{2}{*}{$\begin{array}{c}\text { Responsible } \\
\text { Federal } \\
\text { Agency }\end{array}$} & \multicolumn{2}{|c|}{ Activity Affected. } & \multirow{2}{*}{$\begin{array}{l}\text { Description of } \\
\text { Statute in Text }\end{array}$} \\
\hline & & & Planning & Operations & \\
\hline Safe Drinking Water Act (SDWA) & & & & & IV-35 \\
\hline Technical Assistance & 40 CFR 35 & EPA & $\mathrm{X}$ & & \\
\hline Drinking Water Standards & 40 CFR 142 & EPA & & $\mathrm{X}$ & \\
\hline Underground Injection & 40 CFR 146 & EPA & & $\mathrm{X}$ & \\
\hline Solid Waste Disposal Act (SWDA) & & & & & IV -38 \\
\hline $\begin{array}{l}\text { and Resource Conservation and } \\
\text { Recovery Act (RCRA) }\end{array}$ & & & & & \\
\hline Technical Assistance & $40 \mathrm{CFR} 35$ & EPA & $\mathrm{X}$ & & \\
\hline Solid Waste Disposal Guidelines & 40 CFR 241 & EPA & $\mathrm{X}$ & $\mathbf{x}$ & \\
\hline Hazardous Waste Disposal & Forthcoming & EPA & $\mathrm{x}$ & $\mathrm{x}$ & \\
\hline Surface Mining Control and & & & & & IV -40 \\
\hline Reclamation Act & Forthcoming & DOI & $\mathrm{X}$ & $\mathrm{x}$ & \\
\hline Trust Responsibilities: Lease & & & & & \\
\hline Management & & & & & IV-44, IV-49 \\
\hline $\begin{array}{l}\text { Exploration, Mining, and } \\
\text { Reclamation Policy }\end{array}$ & 25 CFR 177 & BIA/GS & $\mathrm{x}$ & $\mathrm{X}$ & \\
\hline Exploration, Mining, and & & & & & \\
\hline Reclamation Operating Guidelines & 30 CFR 231 & GS/BIA & & $\mathbf{x}$ & \\
\hline Historic Preservation & 25 CFR 132 & BIA & $\mathrm{x}$ & & \\
\hline
\end{tabular}


EXHIBIT IV-5 •

MAJOR FEDERAL ENVIRONMENTAL LAWS AND REGULATIONS AFFECTING OIL SHALE DEVELOPMENT

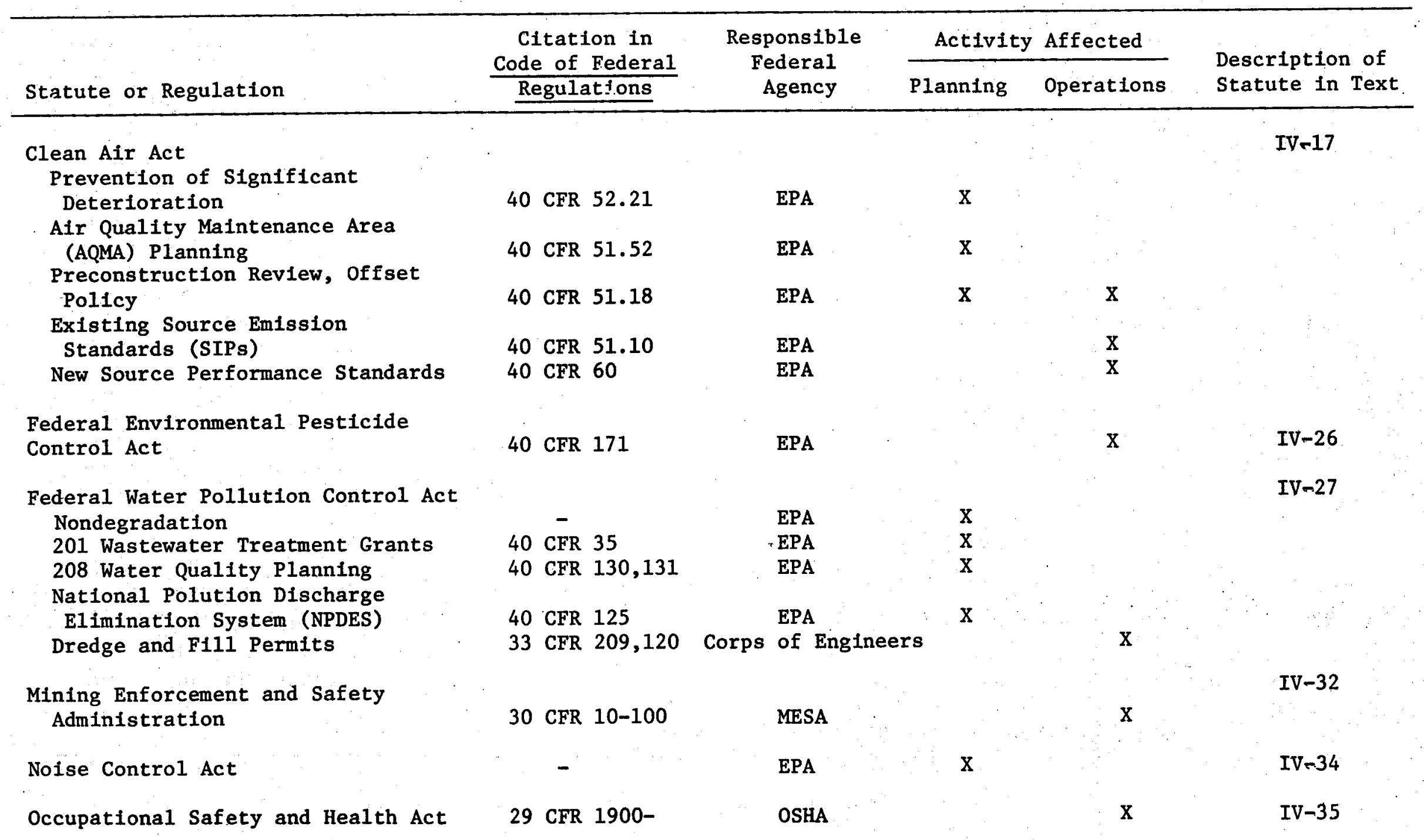

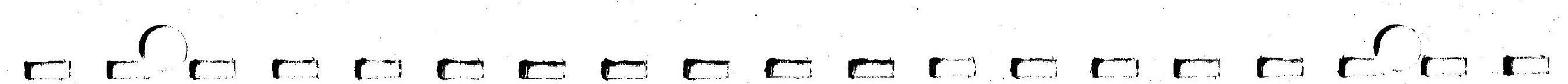


EXHIBIT IV-5 (Cont.)

\begin{tabular}{|c|c|c|c|c|c|}
\hline \multirow[b]{2}{*}{ Statute or Regulation } & \multirow{2}{*}{$\begin{array}{c}\begin{array}{c}\text { Citation in } \\
\text { Code of Federal }\end{array} \\
\text { Regulations }\end{array}$} & \multirow{2}{*}{$\begin{array}{c}\text { Responsible } \\
\text { Federal } \\
\text { Agency }\end{array}$} & \multicolumn{2}{|c|}{ Activity Affected } & \multirow{2}{*}{$\begin{array}{l}\text { Description of } \\
\text { Statute in Text }\end{array}$} \\
\hline & & & Planning & Operations & \\
\hline Safe Drinking Water Act (SDWA) & & & & & IV -35 \\
\hline Technical Assistance & $40 \mathrm{CFR} 35$ & EPA & $\mathrm{x}$ & & \\
\hline Drinking Water Standards & 40. CFR 142 & EPA & & $\mathbf{X}$ & \\
\hline Underground Injection & 40 CFR 146 & EPA & & $\mathrm{x}$ & \\
\hline $\begin{array}{l}\text { Solid Waste Disposal Act (SWDA) } \\
\text { and Resource Conservation and }\end{array}$ & & & & & \\
\hline Recovery Act (RCRA) & & & & & IV -38 \\
\hline Technical Assistance & 40 CFR 35 & EPA & $\mathrm{X}$ & & \\
\hline Solid Waste Disposal Guidelines & 40 CFR 241 & EPA & & $\mathrm{X}$ & \\
\hline Hazardous Waste Disposal & Forthcoming & EPA & $\mathrm{x}$ & $\mathrm{X}$ & \\
\hline $\begin{array}{l}\text { Surface Mining Control and } \\
\text { Reclamation Act }\end{array}$ & Forthcoming & DOI & $\mathrm{x}$ & $\mathrm{x}$ & IV -40 \\
\hline $\begin{array}{l}\text { Trust Responsibilities: Lease } \\
\text { Management }\end{array}$ & & & & & IV $-44, \quad$ IV -49 \\
\hline Exploration, Mining, and & & & & & \\
\hline $\begin{array}{l}\text { Reclamation Policy } \\
\text { Exploration, Mining, and }\end{array}$ & 25 CFR 177 & BIA/GS & & $\mathrm{x}$ & \\
\hline Reclamation Operating Regulations & 30 CFR 231 & GS & & $\mathbf{x}$ & \\
\hline Historic Preservation & 25 CFR 132 & BIA & $\mathrm{X}$ & & \\
\hline
\end{tabular}


EXHIBIT IV-6

MAJOR FEDERAL ENVIRONMENTAL LAWS AND REGULATIONS AFFECTING GEOTHERMAL DEVELOPMENT

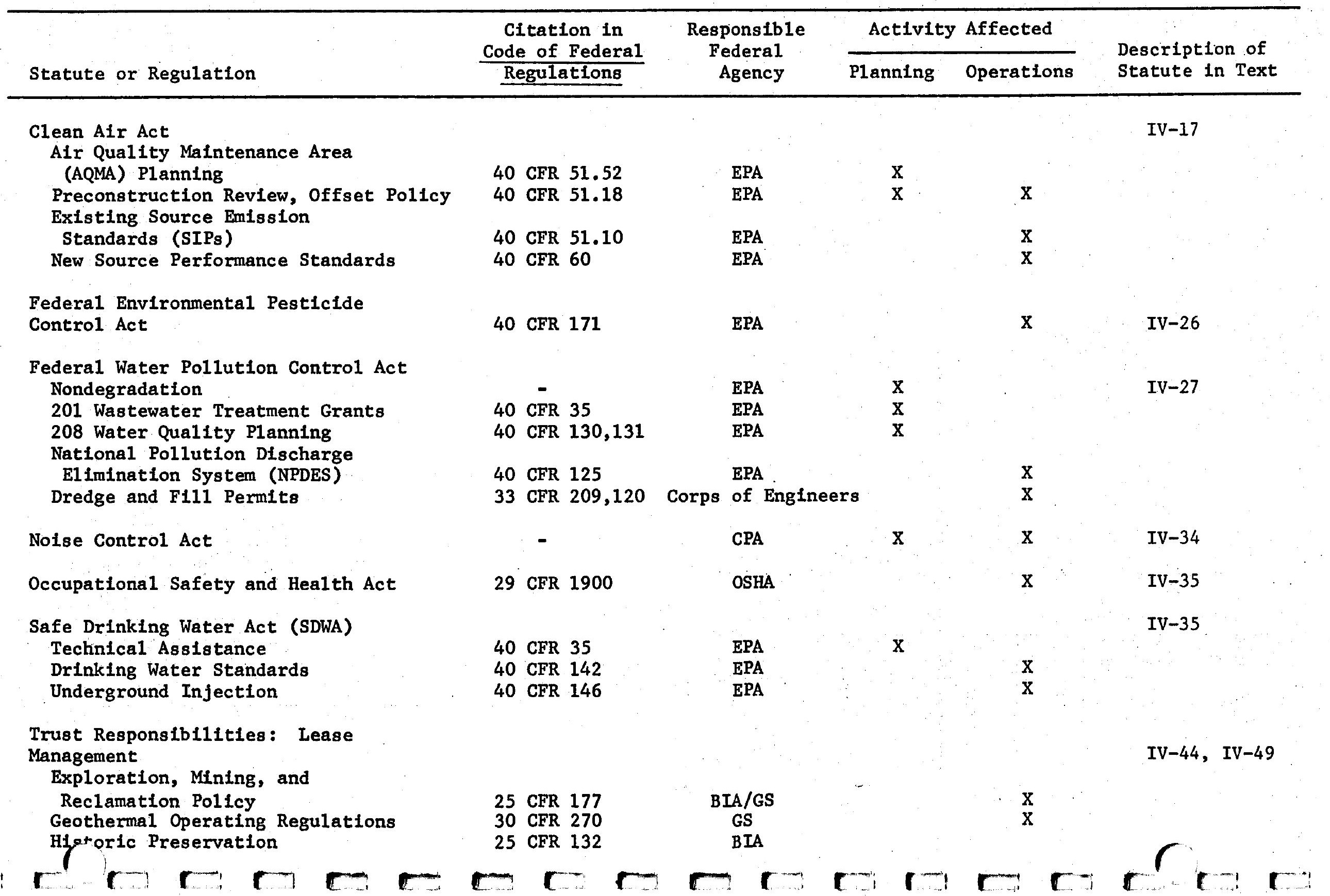


The Atomic Energy Act

Under the Atomic Energy Act, the Nuclear Regulatory Commission 1/. (NRC) has been delegated responsibility for regulating facilities associated with uranium $2 /$ and nuclear fuel cycles. The NRC issues licenses for all activities involving (1) source materlals (uranium, thorlum, and other materials and/or ores as defined by the NRC); (2) by-product materials (materials made radloactive in the process of producing or using "special nuclear materials"); and (3) special nuclear materials (enriched uranium, plutonium, and similar materials defined by the NRC).

Al1 11censees must comply with two sets of standards: (1) those that specifically apply to the activities within the geographic boundaries of the Ilcense (e.g., the mill site) and (2) those that limit the level of radiation outside of the licensee's geographic boundaries (e.g., areas that are adjacent to uranium facilities). The NRC's "standards for protection against radiation" apply to the activities within the permit site. They prescribe standards for (1) permissible doses and levels and concentrations of radiation in restricted and unrestricted areas; (2) precautionary measures to prevent excessive exposure; and (3) methods of waste disposal. Under the Reorganization Plan No. 3, 1970, the Environmental Protection Agency (EPA) was delegated responsibility for the development of generally applicable standards for protection against all radiation levels outside the boundaries

1/ The Atomic Energy Act originally delegated these authorities to the Atomic Energy Commission (AEC). However, the Energy Reorganization Act of 1974 abolished the AEC and transferred the regulatory functions to a newly created NRC.

2/ For the purposes of these regulations, the uranium fuel cycle begins with milling operations. The Act specifically excluded uranium mining from the scope of these federal regulations. 
of the licensed activity. In January 1977, the EPA issued regulations for ambient radioactivity resulting from the uranium fuel cycles. These regulations apply to the radiation that results from milling, conversion, enrichment, generation, Light Water Reactors (LWR), and reprocessing plants, but exclude mining activities. Standards for solid waste disposal and transportation are to be issued at a later date. The effective date for these regulations is 1979, with the exception of milling operations, for which standards must be met by 1980. (EPA is waiting for the results of a joint NRC/EPA three-year study and EIS on milling operations before adopting the regulations.) Standards and criteria for radioactive emissions from activities other than those in the uranium cycle currently are under development (e.g., radon daughters found in phosphates, western coal, and medical equipment). The radiation regulations that may be most pertinent to the mountain states are the standards for milling operations. The NRC permits include conditions that require mill operators to ensure that the tailings area will be stabilized and reclaimed when the milling activities are completed. Recent licenses include basic stipulations that prohibit the exposure or release of tailing materials into the surrounding area and disallow the development of any subdivisions, structures inhabited by man or animal, roads, trails, or rights-of-way on covered tailings. These requirements are binding on the licensee and successive owners for 50 years unless modified by new federal regulations. By 1980, mill operators also will be subject to EPA's standards for radiation introduced into the general environment by their activities. 
Enforcement Jurisdiction. Thls Act provides for NRC enforcement of the license requirements and other standards (e.g., EPA's ambient radiation standards), but allows the NRC to enter Into an "agreement" with states for delegation of certain standard-setting and enforcement responsibilities to them. The law disallows state regulation of production and utilization facilities (1.e., only the NRC regulates nuclear reactors or special materials that are in a sufficlent quantity for critical mass). "Agreement states" may regulate such activities as miling operations and activities not regulated by the federal government (e.g., uranium mining). Arizona, Colorado, New Mexico, and Washington are "agreement states"; South Dakota, Utah, and Wyoming are not.

Indian tribes were not included in the definition of "states" in the 1954 Act; therefore, the NRC cannot delegate "agreement state" authority to the tribes. The NRC w11l enforce its regulations in all non-agreement states. In agreement states, it is the Commission's tentative position to enforce them for Indian activities on Indian lands and to allow state regulation over non-Indian activities on tribal lands. (The policy with regard to agreement states has not been resolved because there are no active mills on tribal lands and the abandoned mills were active before the states galned "agreement" status.)

The Clean Air Act Amendments of 1970 (PL 91-604) and 1977 (PL 95-95)

The Clean AIr Act Amendments of 1970 and 1977 require EPA to adopt standards for national ambient air quality; mandate the development of programs to achieve the standards; and set a strict timetable for Implementation. EPA issued two sets of ambient a1r quality standards for designated pollutants: "national primary air quality standards" (required for public 
health), and "national secondary air quality standards" (required to protect public welfare.) At this time, standards have been set for the following "criteria". pollutants: particulates, sulfur oxides, nitrogen oxides, and hydrocarbons. The Act stipulates that the primary standards must be achieved no later than 1975 and/or 1977. Four major programs were created to implement these standards: (1) States were assigned primary responsibility for assuring that air quality in the state met the national goals; they develop and administer "state implementation plans" (SIPs) that include measures to prevent "significant deterioration," and provide for preconstruction review, and such control measures as emission standards for existing stationary point sources; (2) EPA must adopt performance standards for major categories of "new" stationary sources of pollution that are administered and enforced by the states; (3) EPA must issue emission standards for "hazardous" air pollutants that are to be implemented by the states; and (4) EPA must impose mobile source (e.g., motor vehicles) emission standards. (Mobile source standards will not be discussed herein.)

The following paragraphs discuss the Act's planning and management provisions, performance standards, and administration and enforcement provisions. These more detailed descriptions are presented for three major Acts: the Clean Air Act, the Federal Water Pollution Control Act, the Safe Drinking Water Act, and the Surface Mining Control and Reclamation Act.

Planning and Management Provisions. The Act mandates the use of control strategies that will attain and maintain the ambient air quality standards. Therefore, EPA requires states to include procedures for 
following three planning mechanisms in their SIPs: (1) designation of areas for controls to prevent significant deterioration of air quality; (2) "offset" policies for preconstruction review of new or modified sources; and (3) air quality maintenance programs. A11 three mechanisms may affect prospective energy developments.

The first program, Prevention of Significant Deterioration (PSD), pertains to areas whose current air quality is better than one or more of the secondary standards for ambient air quality. All states are required to include in their SIP emission IImitations and other measures that may be needed to prevent significant deterioration. The 1977 Amendments set forth standards for (1) the designation of areas subject to the PSD regulations, (2) emission limitations, and (3) a preconstruction permit program. Most areas with air quality cleaner than the secondary standards inftially are designated as "Class II" (allowing a moderate decrease in ambient air quality). I/ Procedures are avallable for redesignation to either "Class I" (a1lowing a sma11 decrease in amblent air quality) or Class III (allowing deterioration to the national secondary ambient air quality standards). According to the Act, "(1)ands within the exterior boundaries of reservations of Federally recognized Indian tribes may be redesignated only by the approprlate Indian governing body" (Section 164.c). When exercising this authority, the Indian governing bodies must comply with the provisions of Section $164 . e$ of the Act, which provides procedures to reconcile any conflicts between the tribe and state officials. The Northern Cheyenne

1/ The exceptions to this blanket designation are national parks, monuments, wild and scenic rivers, wilderness and certain other federally managed areas. They have been assigned a "Class I" status. 
reservation was the first area in the nation to be redesignated a "Class I" area. The Act also provides emission limitations for each of the three classifications. Standards are set forth for the "maximum allowable increases" over the baseline level of sulfur oxide and particulates, and for "maximum allowable concentrations" of these two pollutants. Regulations covering the other criteria pollutants (e.g., hydrocarbons, nitrogen oxides, carbon monoxide, and petrochemical oxidants) are to be promulgated by EPA by 1979. Finally, the Act prohibits the construction of any major emitting facility $1 /$ until a permit has been issued for the particular facility. Procedures and guidelines for permit criteria, evaluation, and approval are provided in the law.

Second, states are required to review all new and modified pollution sources before they are constructed to ensure that the facility will not "interfere with" the attainment or maintenance of the national air quality standards. Such preconstruction reviews for facilities in "nonattainment" areas have become increasingly important as the 1977 deadline for achieving primary air quality standards passes. The 1977 Amendments have established one set of procedures for use until July 1979, and another for after that date. Until the 1979 deadline, federal and state authorities must comply with the provisions of an "interpretive ruling" by EPA in December 1976. This ruling provides special guidance for preconstruction review to those states having "non-attainment" AQCRs. EPA ruled that major new sources may not locate in these areas unless certain stringent conditions are met.

1/ The law defines major facilities to include two groups of pollution sources: (1) certain industrial sources, such as electric power plants; and (2) any source that emits more than 250 tons/year of sulfur oxide or particulates. The latter definition includes surface mines. 
The three basic requirements are (1) that the new source meet the "lowest allowable emission rate" (standards at least as stringent as the standards of performance for new sources); (2) that more than equivalent "emission offsets" will be obtained from existing sources; and (3) that even with the additional source, the area will progressively improve its air quality rather than maintain the status quo, or just achieve the primary standards. By providing for conditional approval of new sources, EPA hopes to avoid a "no-growth" policy for "nonattainment" areas. However, if the proposed new or modified source cannot meet these conditions, then the construction permit must be denied. After July 1979, states having "nonattainment" areas will be required to include comprehensive measures in their SIPs. The plans must provide for (1) a permit program for the new sources planned for the areas; (2) other policy and regulatory mechanisms to implement the program; and (3) the collection and analysis of emissions in the area. These construction stipulations could hamper energy development on reservations in the Four Corners AQCR (because the particulate levels exceed the primary standards) $1 /$ and in the Uinta basin area in Utah (due to the levels of particulates, hydrocarbons, and ozone). $-2 /$ Exhibit IV-7 provides a map of the AQCRs that were in "nonattainment" status for at least one criteria pollutant as of August 1976.

If EPA is studying the source of the particulate matter in the Four Corners area because it may be a "fugitive," natural source rather than a manmade source. This determination will affect the preconstruction measures taken by the states and EPA.

2/ Air quality studies of the sites of the prototype oil shale lease tracts in Colorado and Utah measured levels of these pollutants that exceed the levels allowed under the primary air quality standards. Like the Four Corners area, this is attributed to "fugitive" sources. It may be noted that the area is not indicated as being in "nonattainment" status In Exhibit IV -7 because the measurements were not taken as part of EPA's nationwide monitoring program. However, developers of the oil shale tracts are expected to comply with the "nonattalnment" regulations as a requirement of the leases. 


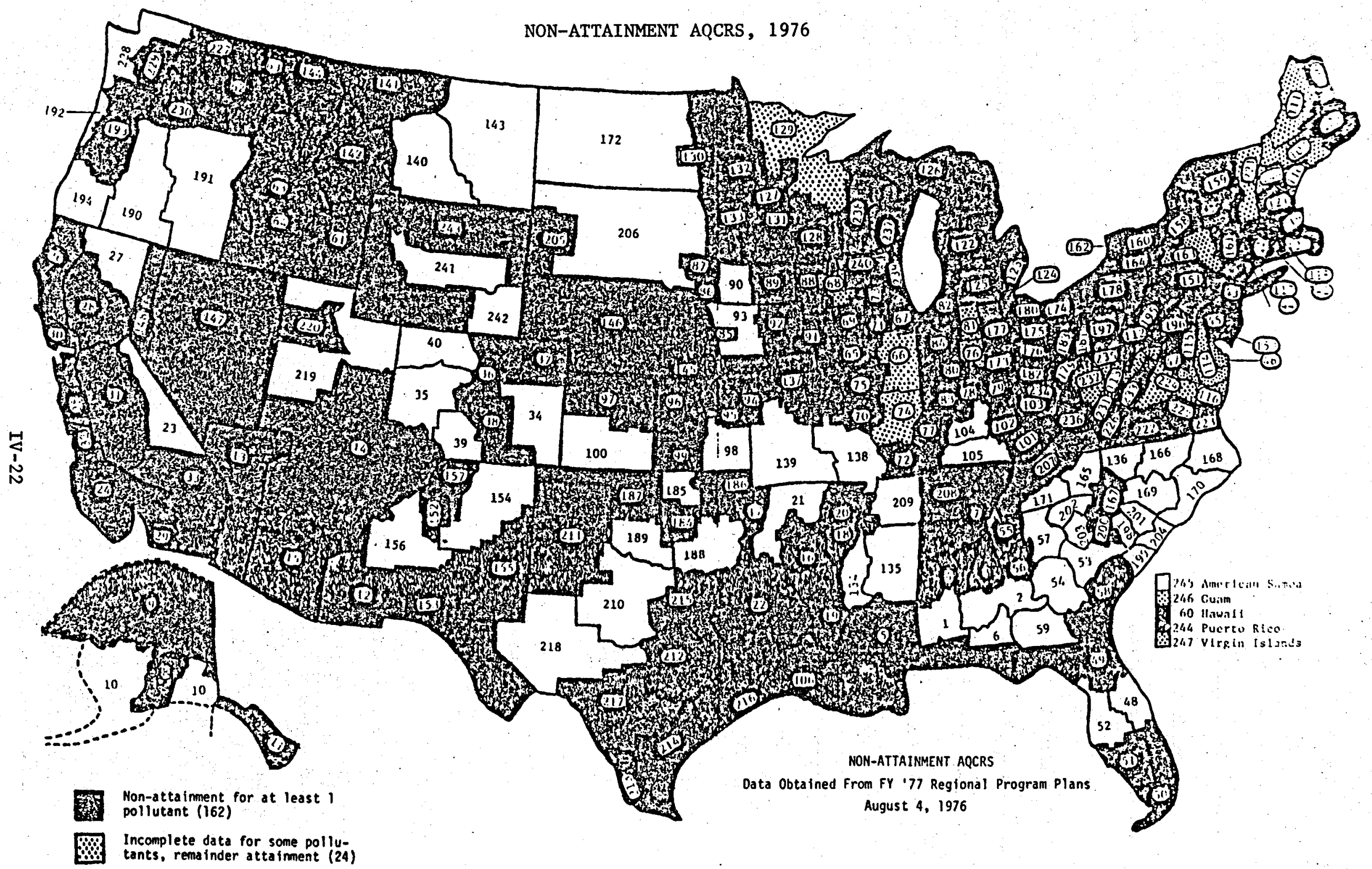

Source: Environmental Protection Agency, December 22, 1976.

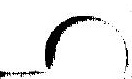


Third, EPA regulations require all SIP's to indicate those geographic areas in the state that, for certain reasons, $1 /$ may exceed any national air quality standard over the next 10 to 20 years. For those areas where this is considered likely, the state is directed to develop an Air Quality Maintenance Area (AQMA) plan to mitigate the antlcipated growth in emissions. AQMA plans are to be prepared with the cooperation of local and regional governments, "208" water quality planning agencies (see description under Federal Water Pollution Control Act), units dolng comprehensive plans under "701" grants from HUD, and other appropriate authorities. According to the existing state plans, the following tribes are within AQMAs: Northern Cheyenne, Crow, Fort Berthold, Uintah and Ouray, Osage and Navajo.

Performance Standards. Three of the control measures mandated by this Act affect energy-related facilities:

(1) State Implementation Plans. The state "control strategy" consists of four major components:

(1) measures to reduce emissions from existing "puint" and "indirect" sources; 27 (2) provisions for the prevention of siynificant deterioration; (3) preconstruction review; and (4) AQMA plans. The stationary source controls may include emission limitations for sulfur oxides, particulates, carbon monoxide, nitrogen oxides, and hydrocarbons. State emission control must be sufficient to achieve the primary and secondary air quality standards, and

1/ Factors include the current air quality of an area, projected population growth, the siting of energy conversion faclities, etc.

2/ "Point" sources Include stationary sources that cause a certain level of emissions and are major pollutant sources, such as the chemicals industry, petroleum refining, food and agricultural industries, and others so designated by EPA. "Indirect" sources are operations that themselves do not emit a significant level of pollutants but that have mobile source activities. (emissions) associated with their operation (e.8., a large shopping center). 
EPA provides guidance on what it believes are attainable limitations using "reasonably available technology." If the plan is deficient in some part, EPA issues sufficiently stringent standards before approving the plans. However, state standards may be more stringent than the federal standards. Controls for "indirect" sources may include special taxes and other approved programs. (Under the 1977 Amendments, land use plans no longer are considered a control strategy.) The other three features of the SIPs were described above.

(2) "New Source" Standards of Performance. Prior to the 1977 Amendments, EPA promulgated emission limitations for new stationary sources (i.e., those operations for which planning or construction of major modifications or new facilities was begun after the effective date of the regulations). Standards of performance had been issued for major industries, including fossil-fuel-fired steam generators; coal preparation plants; and petroleum refineries.

The 1977 Act strengthened the regulation of new sources. EPA is authorized to set "standards of performance" that may be based either on technological controls (e.g., specifications on the design, construction, equipment, operating aspects of the facility). Stationary sources using fossil fuels are required to comply with two standards: one for allowable emission levels and one for a required percentage reduction in the emissions from standard fuels. The Act directs EPA to delegate responsibility for enforcing these standards to the states if the state meets certain conditions.

(3) "Hazardous Pollutant" Standards. EPA is authorized to regulate hazardous air pollutants through either emission limitations based on a control technology or through standards of performance based on non-technological factors such as facility design, construction, and operation. To date, EPA has issued performance standards for such hazardous wastes as mercury, beryllium, and asbestos.

(4) Presently "Unregulated Pollutants." The 1977 Act directs EPA to determine whether certain unregulated substances cause or contribute to air quality characteristics that may endanger public health or increase the number of illnesses and deaths. EPA must evaluate the following elements within one year of the enactment: cadmium, arsenic, and polyorganic materials. Importantly, radioactive pollutants, which are defined to include naturally radioactive substances (e.g., emissions from 
uranium mines as well as those covered by the Atomic Energy Act, are to be studied within two years of enactment. In conjunction with these studies, EPA is to determine whether these pollutants should be regulated as hazardous pollutants, new sources, and/or as a named, "criteria" pollutant. In the case of radioactive pollutants, the Amendments provide special procedures for coordination among EPA, the NRC, states, and localities.

Enforcement Jurisdiction. Although EPA is responsible for determining national alr quality standards, emission limitations, performance standards, and the adequacy of state plans, the major strategles created by the Clean Air Act Amendments rely on enforcement by states. States in turn may delegate certain enforcement responsibilities to $10 \mathrm{cal}$ authorities. EPA provides financial and technical assistance to state and local air quality monitoring and enforcement agencles. As of 1976, South Dakota and Utah were among the states that had assumed responsibility for Implementing "new source" standards; Colorado and Washington had assumed responsibility for both "new source" and "hazardous pollutant" standards. All states had SIPs, but many have been modified by EPA.

Enforcement jurisdiction activities on Indian lands are untested with regard to either state implementation plans or new source performance standards. Generally, states do not have jurisdiction over Indian lands unless federal law expressly delegates such authority to the states. The Clean Air Act is silent regarding the extension of state air pollution programs to Indian lands. Thus, EPA belleves it unlikely that states would have enforcement authority, via their SIPs, over alr pollution sources on Indian lands within the states' boundaries. A180, since 
tribes are not included in the Act's definition of a "municipality," they have not, to date, been considered eligible to adopt and implement their own implementation plans. Federal funds may be available for tribal monitoring programs, but not for development of an enforcement capability. At this time, EPA plans to handle the jurisdictional questions on a case-by-case basis. However, EPA does retain ultimate authority to enforce federal standards; therefore, tribal protection is guaranteed.

Federal Environmental Pesticide Control Act of 1972 (PL 92-516)

This Act amended the Federal Insecticide, Fungicide, and Rodenticide Act (FIFRA) for three purposes: (1) to require the registration and classification of pesticides, herbicides, and similar chemicals;

(2) to require certification of those who apply them, and extend their liability for misuse; and (3) to promulgate guidelines for the safe storage and disposal of these chemicals and related equipment. These EPA regulations control the application of herbicides and other retardants used for electric, gas, and other utility rights-of-way; oil or gas well-sites; mine reclamation; and similar activities.

States have been delegated most of the enforcement responsibilities for these regulations. However, Part 171.10 of EPA's pesticide regulations specifically pertains to "Certification of Applicators on Indian Reservations." Under these provisions, a tribe that is not subject to state jurisdiction and that has an appropriate governing body may elect either to use the state certification program or to develop its own plan for certifying commercial and private applicators. If a tribe chooses to adopt and enforce its own regulations, it should enter into a cooperative agreement with the state on 
enforcement matters. Furthermore, its rules should be based on either state or federal guldelines, and must be approved by the EPA through the Department of the Interior. Non-Indians using restricted pesticides on reservations that are not subject to state furisdiction must be certified either under the Tribal certification plan or a state plan accepted by the tribe.

Federal Water Pollution Control Act (FWPCA) Amendments of 1972 (PL 92-500) $1 /$

When the Congress passed the FWPCA amendments of 1972 , the approach to pollution control differed from that adopted for alr quality. This Act places greater emphasis on controlling pollution at the point of discharge than on the amblent water quality of the nation's waterways. The Act established a goal of "zero discharge" of pollutants into navigable waters by 1985. Interim goals for reducing effluent discharges into navigable rivers were set for 1977 and 1983. There are faur major components of the national water pollution control program: (1) a National Pollution Discharge Elimination System (NPDES) that sets effluent limitations for existing and new point sources and requires an NPDES permit before discharges will be allowed; (2) spectal restrictions on o1l and similarly hazardous materials; (3) funding for state and areawide water quality planning and management; and (4) grants for the construction of wastewater treatment facilities.

Planning and Management Provisions. The FWPCA provides funding for four aspects of water quality planning and management: construction

1/ This law was amended after this report was finalized. See the Clean Water Act of 1977, P.L. 95-217. 
grants for public wastewater treatment systems, state and areawide planning, river basin planning, and measures to prevent degradation of high-quality waters.

First, under the NPDES, publicly owned wastewater discharges must comply with the EPA effluent limitations. Section 201 of the Act allows EPA to provide matching funds for the planning and construction of wastewater treatment facilities. To qualify for such funds, the project must be included as a priority in the state plans and have state approval. When states identify priority areas, they are required to emphasize the severity of the pollution, but must also consider the population affected, nondegradation of clean water, and consistency with the areawide and basin plans. Several tribes have made use of 201 funds, including the Navajo, Jicarilla, Yakima, and Fort Berthold.

Second, Section 208 provides federal support for comprehensive planning for water quality control on an areawide and/or state basis. Areawide planning agencies are designated either by the state governor(s) or by special procedures for self-designation. The criteria used to designate areawide agencies include the impacts of urban/industrial concentration, energy development, and/or the protection of unique scenic or recreational waters. The 208 plans develop a profile of anticipated development for the next 20 years; identify the point and non-point source impacts of that development; evaluate the feasibility and effectiveness of alternative systems to prevent pollution discharges and maintain (or improve) water quality; and identify the governmental units that will plan, finance, and construct the necessary facilities. Also, the 208 comprehensive plans are coordinated with areawide air quality maintenance plans, solid waste management, and land-use planning efforts. 
Under the FWPCA, Indian tribes or an "authorized tribal organizatIon" are assigned the legal status of a municipality. As a result, tribes are eligible for wastewater treatment construction grants, and they participate in water quality management programs. EPA has issued a policy memorandum specifically addressing tribal participation in 208 planning. This memo, "SAM-7," states that water quality management agencies must coordinate with all tribes within the designated area. The nature of tribal participation depends on the particular legal relationship between the tribes and the other jurisdictions. If the tribe is independent of state jurisdiction, then the tribe may opt efther to be included in the areawide effort or to study its water quality problems individually. EPA prefers tribal participation in areawide plans, but has procedures for either approach. If a tribe elects to participate in the areawide agency, EPA requires a tribal resolution or a similarly binding memorandum confirming the tribe's intent to cooperate in developing plans for the entire area. EPA also recommends setting forth specific procedures for representing the tribe's views in the deliberations. Tribes may receive direct funding If the state has no jurisdiction under PL 280 , if subcontracting through the state or designated area is not possible, or if all practical steps to coordinate with the 208 agency have been taken. Other conditions of direct funding are that the state formally affirm that it authorizes part of its 208 allotment fund to the tribe, that it will review and comment on the tribe's plan, that it will input the tribe's plans into state plans, and that the state will coordinate the two efforts. In February 1977, EPA awarded direct 208 grants to ten tribes. 
Section 303(e) of the Act requires state and interstate water quality planning on the basis of river basins. These assessments of point and nonpointsource impacts provide a context to areawide and state 208 plans, construction projects, and the water resources planning done by the Water Resources Council. Finally, Section 302. of the Act enables EPA to restrict effluent discharges into pristine waters. Although a nondegradation program has not yet been adopted, it is expected to parallel the "no significant deterioration" measures under the Clean Air Act.

Performance Standards. The FWPCA created three programs to limit effluent discharges: (1) the NPDES, (2) prohibitions on the discharge of oil or hazardous substances in harmful quantities, and (3) a dredge and fill permit program.

The NPDES is a national permit program that allows, conditions, or prohibits the "discharge of pollutants from point sources into navigable waters, the contiguous zone, or the oceans" (40 CFR 125.1). Permits are contingent upon the following federal and state standards:

(1) Effluent Standards and Limitations. "Existing" point sources are required to use the "best practicable control technology currently available" to control discharges (as defined by EPA) by 1977. By 1983, they must use the "best available technology economically available." EPA has proposed or issued effluent limitation guidelines for most major industrial groups, including power generation facilities and coal and uranium mining activities. "New" point sources must use the "best available demonstrated" control technology. In general, the "new" source standards are equivalent to the 1983 criteria for existing sources. "Nonpoint" sources of pollution 
(e.g., agricultural feedlots, mine runoff, etc.) are responsible for close to $40 \%$ or more of the violations of national water quality standards. Because the discharges are diffused, control of nonpoint sources depends on planning and management programs rather than specific effluent limitations. EPA guidelines require "best management practices," which are being adopted by the appropriate state and local authorities through such vehicles as 208 planning.

(2) Pretreatment Standards. If industrial pollutants either (1) would disable operation of a municipal treatment facility, (2) cause the municipal system to exceed its effluent limitations, or (3) are not treated by such a system, the Act requires that the industry treat the wastewater so that it meets the standards that apply to municipal discharges into receiving waters.

(3) Toxic Effluent Standards and Prohfbitions. Whereas other effluent standards are based on economic and technological criteria, these standards are determined by several toxicity factors. General criteria include: degradability; persistence; toxicity after combination with other substances; concentration in the food chain; and others. However, the law forbids any discharges of warfare agents (chemical, blological, or radiological) or large levels of radioactive wastes into navigable waters.

The FWPCA specifically disallows the discharge of oil or other hazardous substances into navigable or adjacent lands. EPA has issued regulations for the prevention of oll spills. They apply to onshore and offshore oll facilities that, due to location and size, could reasonably be expected to discharge oil in harmful quantities. Onshore owners and operators must prepare and submit a Spill Prevention Control and Countermeasure (SPCC) plan to the EPA. The Agency's guidelines for onshore facilities Include controls for production facilities (wells, floodlines, separation equipment); drilling and workover facilities; drainage facllities (e.g., dikes); bulk storage tanks; transfer facilities, pumping, and in-process facilities; and loading and unloading and racks for tank cars and trucks. 
Finally, Section 404 of the FWPCA authorizes the U.S. Army Corps of Engineers to issue permits for the discharge of dredge and fill materials into navigable waters. If a facility or associated activities would add or withdraw fill or dredge materials to such waters, then a permit would be required. This provision may affect energy conversion facilities, pipelines, electric transmission lines or other activities.

Enforcement Jurisdiction. EPA establishes effluent guidelines to be used for the NPDES permits, but the states that are delegated authority to implement the program are allowed to adopt more stringent standards. Of the ten states that have CERT tribes within their borders, five implement the NPDES: Colorado, Montana, North Dakota, Washington, and Wyoming. The oil and hazardous substances regulations are implemented by the EPA nationwide.

Title 40 of the CFR, Part 125.2, specifically states that federal NPDES regulations, not state laws, apply to both federal agencies and Indian activities on tribal lands. At this time, the states that have assumed NPDES have jurisdiction over non-Indians. In all other states, enforcement is the responsibility of the EPA. Since EPA is responsible for implementing the oil and hazardous substances regulations nationwide, the agency also enforces them on tribal lands.

Mining Safety Acts $1 /$

The Mining Enforcement and Safety Administration (MESA) implements two federal laws that regulate mining activities relating to interstate

1/ These laws were amended after this report was finalized. See the Federa1. Mine Safety and Health Amendments Act of 1977 (P.L. 95-164). 
commerce: The Federal Metal and Nonmetallic Mine Safety Act and the Federal Coal Mine Health and Safety Act of 1969.

The agency is authorlzed to adopt standards, perform inspections, and levy penalties for mining and milling practices that could jeopardize or Impair the workers' safety and health. To date, the regulations have emphasized safety concerns: mine design, the use of explosives, hoisting, dumping, etc. Safety also is stressed in the quarterly inspections of the underground mines; the inspections of surface coal mines three times per year; the annual inspection of all other surface mines; and in the special inspections and accident prevention programs for "very large" mines (1.e., those with 150 or more miners) and "hazardous" mines that have a high accident and/or injury rate. Recently, MESA has proposed to upgrade its regulations, programs, and Inspections for mine health. The agency hopes that its new health-related activities will reduce the incldence of illnesses and diseases that particularly affect miners.

Enforcement Jurisdiction. MESA is responsible for enforcing the coal mines' safety regulations, and does so on tribal lands.

The responsibility for enforcing regulations on Indian lands for minerals other than coal was less clear-cut. The Federal Metal and Nonmetal Mine Safety Act enabled MESA to enter Into an "agreement" with state governments under which state mining authorities may be delegated primary enforcement responsibilities. Six states entered into such agreements: Arizona, Colorado, New Mexico, North Carolina, Utah, and Virginia. In these states MESA monitored the state programs through state reports, federalstate inspections, and federal inspections and investigations. MESA also 
inspected mines in the state and issued orders in cases of danger, but did not issue the notices for violations of federal standards. The proper mix of federal/state enforcement jurisdiction had not been resolved for mines and mills on Indian lands in agreement states. However, the transfer of MESA from the Department of the Interior to the Department of Labor requires federal enforcement of all of the mine safety regulations (coal and other minerals). This eliminates the jurisdictional problems encountered in the agreement states.

Noise Control Act of 1972 (PL 92-574)

This Act adopts a national policy to protect people from noise emissions that jeopardize health and welfare. In keeping with this policy, the Act provides (1) a policy that the primary responsibility for noise control is vested in state and local governments; (2) EPA technical assistance and research on noise control; and (3) EPA noise emission standards for railroads, motor vehicles, construction equipment, other transportation equipment, and certain manufactured products.

Enforcement Jurisdiction. Under this Act, state, local, and other governmental units (e.g., Indian tribes) are encouraged to develop and adopt noise standards without interference from the federal government. The federal government's regulatory role is limited to the transportation and manufactured products 1isted above. As such, it does not control "activities" on tribal lands. 
Occupational Safety and Health Act of 1970 (PL 91-596)

This Act created the Occupational Safety and Health Administration (OSHA) within the Department of Labor to develop safety standards for the work place. OSHA regulates virtually all employers engaged in interstate commerce with a program of standards, on-site inspections, fines, and citations. OSHA regulations include radiation standards for nongovernment operations that are based on the NRC's standards for occupational exposure.

Enforcement Jurisdiction. OSHA enforces these safety regulations on tribal lands in states that do not have an implementation plan (e.g.; Montana, Oklahoma, North and South Dakota). There is dual state/federal enforcement in states that have standards but not an "operations" plan (e.g., New Mexico). In states that do have such plans, the emerging position is that OSHA will enforce the regulations for Indian activities on Indian lands and states will do so for non-Indian activities.

Safe Drinking Water Act (SDWA) of 1974 (PL 93-523)

The SDWA has four major provisions: (1) primary and secondary standards for drinking water supplied by any public community system; (2) controls of underground injections that may contaminate drinking water supplies; (3) special restrictions of projects that might contaminate aquifer recharge zones that serve as primary or sole source of drinking water for a community; and (4) funds for research, demonstration, and technical assistance for water supply systems. 
Planning and Management Provisions. The SDWA includes provisions to facilitate implementation of the water supply and underground water protection programs. First, the Congress has appropriated funds for the purpose of providing municipalities with technical assistance to establish water system management programs. The Act includes tribes in the definition of "municipality"; therefore, tribes are eligible for the research and technical assistance programs. However, these grants can be made only to the states; consequent1y, eligible tribes must receive either the funds or training through the states.

Second, the regulations for the underground injection control program require states to identify all aquifers that must be protected. The implementation plans must designate aquifers that (1) currently supply public water systems or (2) do not presently supply water but that have less than $10,000 \mathrm{mg} / 1$ of total dissolved solids. Likewise, aquifers may be excluded from the program if the state indicates that the area is severely contaminated, is unsuitable due to location, or is strictly used for oil production.

Performance Standards. The SDWA mandates the following three sets of controls:

(1) Public Drinking Water Standards: Any community water system that serves at least 25 individuals or 15 regular customers on a regular basis ( 60 days per year) must comply with primary and secondary water standards. EPA has established interim primary drinking standards that limit organic, inorganic, and microbiological contaminant and turbidity levels. Standards for radioactivity are under development. Also, any new system must site the waterworks to minimize the risks of flooding, fire, and earthquakes and to circumvent tide levels and 100-year flood plains. 
(2) Underground Injection Standards. Under this Act, states are required to submit programs to control underground injections by permits or rules that prevent injections that would "endanger" drinking water sources. EPA's proposed regulations suggest that injections endanger drinking water sources if (1) it becomes necessary for a public water system using the underground source to increase treatment; (2) it might be necessary for a public water system that would use the water source in the future to use more extensive treatment than otherwise would be necessary; or (3) it might adversely affect public health by making the water unfit for human consumption. The rules include guidelines for underground injections by disposal wells, subsidence control wells, mining wells, geothermal wells, and oil and gas operations.

(3) Sole Source Standards. EPA has special review and program implementation procedures for developments that affect aquifer recharge zones that are the sole or principal source of a community's drinking water supply.

Enforcement Jurisdiction. This Act provides for state assumption of primary enforcement responsibilities for primary and secondary drinking water and underground injection standards where the state has the necessary legal authority and a program that complies with EPA guidelines.

The Act stipulates that federal agencies and water systems on Indian reservations must comply with the primary and secondary drinking water standards. For reservations that "own" water systems that are administered by the Indian Health Service (IHS), it will be necessary for EPA to work with the tribes and IHS to identify which authority will be responsible for compliance.

In a special opinion, EPA ruled that these drinking water standards would be administered by the EPA unless the state has authority pursuant to treaties (or enabling statutes) or if the tribe entered into an enforcement agreement with the state. The regulations for underground Injection adopt a similar stance. If a state does not have jurisdiction or its jurisdiction is in question, EPA will enforce the regulations on tribal lands.

1/ At the time this report was completed, the underground injection standards had not been issued as final regulations. 
Sol1d Waste Disposal Act (SWDA) (PL 89-272), Resource Conservation and Recovery Act (RCRA) of 1976 (PL 94-580)

Until the passage of the Resource Conservation and Recovery Act of 1976 (RCRA), the federal approach to solld waste management was dictated by the Solid Waste Disposal Act. The SWDA provided federal financial and technical assistance to states and localities for the purpose of planning and developing environmentally sound methods of land disposal.

With the enactment of the RCRA, the Congress expanded and accelerated federal and state regulation of solld and hazardous wastes. First, the definition of solid waste was amended to include "solid, 1iquid, semi-solid or contained gaseous material," and to exclude materials controlled by the Atomic Energy Act. Second, the RCRA provides for the implementation of state and regional solid waste plans. EPA must publish minimum guidelines for approving these plans; the law spectfically requires the state plans to prohibit new open dumps and to close or upgrade existing ones. If the state plans are approved, the implementing agencies will be eligible for federal funds and assistance. EPA is to encourage a regional solid waste management and to parallel the regions used for 208 planning to the extent practicable. Third, the RCRA provides for the regulation of hazardous wastes based on a permit system for treatment, storage, or disposal of hazardous wastes. EPA is required to Issue regulations that establish (1) criteria for the identification of hazardous wastes, (2) a list of the hazardous wastes to be regulated, (3) regulations for the issuance of permits, and (4) guidelines for the development of state permit programs. Finally, EPA is required to Implement these activities within specified 
time Iimits. Regulations for both hazardous wastes and state solid waste management plans are to be issued within 18 months after the passage of the Act (1.e.; by April 1978).

Even though no regulations have been finalized for waste management, the agency has identified its initial approach to each area. In the case of hazardous wastes, EPA is directing its efforts toward developing standards for six aspects of this program:

- The identification of the hazardous wastes to be regulated. The criteria are likely to reflect toxicity, flammability, corrosiveness, and persistence and degradability in nature.

- The regulation of activities of generators of hazardous wastes. The standards are expected to emphasize the use of appropriate containers, labeling, and recordkeeping.

- The regulation of activities of owners and operators of facilities to store, treat, or dispose of hazardous waste. Guidelines are expected to address the design, location, and construction of facilities as well as recordkeeping, reporting, and monitoring requirements.

- The issuance of permits by EPA or authorized state agencies. In addition to the performance criteria, EPA is establishing the administrative procedures that will govern the issuance of permits.

- The delegation of permitting authority to states. $E P A$ is In the process of publishing guidelines and criteria for authorizing state permit programs and per grants.

- The study and evaluation of current approaches to hazardous waste management.

The regulatory programs for solld waste are expected to Include revisions of existing solid waste disposal guidelines and new standards for the disposal and utilization of sludge. 
Enforcement Jurisdiction. The solid waste plans are to be administered and enforced by state and regional authorities, subject to certain federal prerequisites, such as the mandatory prohibition of open burning. The hazardous waste management program will be implemented by EPA and states that have EPA-approved plans.

Neither the SWDA. nor the-RCRA specifically addresses enforcement for activities on tribal lands. A legal opinion by the EPA general counsel is pending on this question.

Surface Mining Control and Reclamation Act of 1977 (SMCRA) (PL 95-87)

This recently enacted law parallels other environmental statutes in its approach to controlling the impacts of surface mining activities. The SMCRA includes the three components found in other acts: planning and management programs; performance standards; and enforcement mechanisms. Like the prior laws, this Act requires a federal agency--in this case a new Office of Surface Mining Reclamation and Enforcement in the Department of the Interior--to set forth minimum performance standards. These standards are to be implemented through a permit system. Authority to administer and enforce the standards is vested in this agency until delegated to states with federally approved implementation plans. Initially, the office will enforce the standards on Indian lands, but the Department is required to propose legislation that would give tribes the authority to enforce the law on their own lands.

The measures in this Act principally address the mining of coal, but provisions have been made for adopting similar programs for other minerals at a future date (e.g., the study of ofl shale mining must be submitted with- 
in the year of enactment; the study of surface and open pit mining of other minerals, within eighteen months).

The following discussion highlights basic requirements of the Act. The rules and regulations that will implement these broad directives had not been issued at the time of this writing.

Planning and Management Provisions. This Act creates three sets of programs to improve the planning and management of surface mining activities. First, all state and federal implementation plans must include a planning. process for designating areas that are unsuitable for surface coal mining. Factors that might render an area "unsultable" include conflicts with existing land use plans; the historic, cultural, or similar value of the area; the value of the area as a source of renewable resources (e.g., water supply, food or fiber products), and/or natural hazards. The designation process must include (1) sufficient data and analyses to support the determinations; . (2) methods for implementing land use decisions that affect the coal mining operations; and (3) provisions for public particlpation in the decision-making process. The law also provides for the designation of federal lands that may be unsuitable for mining minerals other than coal. Second, the law also creates a special program for reclaiming abandoned coal mines. This effort is to be funded by a fee to be levied on all operators that are subject to the Act. Finally, the law includes authorizations for numerous research and demonstration programs.

I/ Section 402(a) of the Act sets forth the following fee schedule: either 35 cents/ton of coal from surface mines and 15 cents/ton of coal from underground mines or 10 percent of the value of the coal, whichever is less. For lignite, the rate shall be 10 cents per ton or 2 percent of the value, whichever is less. 
Performance Standards. After a specified date, no coal exploration or mining operation will be allowed unless a federal or state permit has been approved. Each permit must include data on the operator, the proposed mining plan, an overview of the environmental impacts of the operation, and other mandated information. Importantly, the permit application must include a detailed reclamation plan. Also, any approved plan must be accompanied by a performance bond sufficient to cover the costs of reclamation, but in no case less than $\$ 10,000$ for the area covered by an individual permit. The permits that are issued will require the operators to meet minimum performance standards developed by the federal office. (State standards must be as stringent as the federal regulations before the state can be delegated primary enforcement authority). The law establishes general performance standards for major mining activities; it includes requirements for:

- Restoring the land to the approximate original contour

- Restoring the area to a condition capable of supporting uses that are similar or "higher," "better" uses than before the mining operation

- Restoring the mined area in an "environmentally sound manner," and as contemporaneously as practicable with the mining operations

- Revegetating the area with appropriate vegetative cover, and assuming responsibility for revegetation for 5 to 10 years, depending on the rainfall on the area

- Limiting water impoundments, protecting the hydrology of the mine site to prevent contamination of surface of groundwater 
- Controlling the disposal of all mine wastes, pilings, and spoils.

Enforcement Jurisdiction. Under this Act, states may assume primary enforcement authority if their implementation plan is approved by the Department of the Interior. However, the Act includes special measures for enforcement on Indian lands. The law requires interim compliance with the federal performance standards to be enforced by the Department while enabling a transition to direct tribal control. The Department is required to submit legislation that will allow tribes to opt for a legal status equivalent to the states. Section 710 stipulates that:

(1) All surface coal mining operations must comply with environmental protection performance standards at least as stringent as those in Title $V$ on or after 135 days after enactment of this bill. If enforcement requires any modifications of existing leases, Department of the Interior approval is necessary. I\%

(2) Thirty months after the bill is signed into law, all coal mining operations must comply with other key parts of Title $V$. These conditions will be incorporated into all existing leases subject to Interior Department approval.

(3) The Secretary of the Interior is directed to study the question of regulation of surface mining on Indian lands and to draft legislation that would "allow tribes to elect to assume full regulatory authorfty over the administration and enforcement of regulation of surface mining of coal on Indian lands." Tribes must be consulted in the preparation of the study, and the final report must include the views of each tribe that would be affected. No more than $\$ 700,000$ may be appropriated for this report, which would be due January $1,1978$.

1) In December 1977, BIA adopted the Office's coal standards for operations on Indian lands (25 CFR 177, Subpart B). 
Toxic Substances Control Act of 1976 (PL 94-469)

This Act mandates the direct regulation of chemicals in order to prevent unreasonable health and environmental risks related to their manufacture, distribution, use, and disposal. Controls are imposed on the basis of three major provisions: (1) The Administrator of EPA must test any chemical if it may present an unreasonable risk; if there are insufficient data on which to determine health and environmental effects; or if testing is needed to develop data. Priority chemicals will be determined by members of a special federal advisory committee; (2) All chemical manufacturers are required to notify EPA 90 days in advance of the first commercial manufacture of a chemical; during this period, the Administrator may require testing or apply restrictive rules; and (3) The Administrator may prohibit the manufacture or sale of a chemical if it poses unreasonable risks or may simply require labeling if its impacts are less serious. The Act also provides for consumer reporting, citizen participation, and employee protection. Importantly, this Act does not apply specifically to materials within the scope of the Atomic Energy Act.

\section{Tribal Trust Responsibilities: Lease Management}

Pursuant to several enabling statutes, the Department of the Interior has been delegated responsibility to serve as trustee for Indian mineral estates. Lease management activities on tribe lands currently involve three parties. The Bureau of Indian Affairs (BIA) and the tribes fointly perform the role of lease manager: They decide whether, when, where, and under what conditions to lease. The Conservation Division of the U.S. Geological Survey (USGS) acts as their technical advisor on lease decisions and enforces the 
conditions of all permits and leases for all tribes other than Osage. The existing trust-related regulations that offer environmenţal protection include: Preservation of Antiquities (25 CFR 132); Surface Exploration, Mining, and Reclamation of Lands (25 CFR 177); Leasing of Osage Reservation Lands for 0il and Gas Mining (25 CFR 183); 011 and Gas Operating Regulations (30 CFR 221); Operating Regulations for Exploration, Development, and Production (30 CFR 231); and Geothermal Resources Operations on Public, Acquired, and Withdrawn Lands ( 30 CFR 270). These are described briefly below.

Historic Preservation (25 CFR 132). Pursuant to the 1906 American Antiquities Act and Historic Preservation Act of 1966, the federal government mandated procedures to protect (undefined) antiquities. In practice, compliance with these regulations requires a site inspection by an archeologist registered with the National Park Service before any activity that would disturb lands in designated areas is permitted.

\section{Surface Exploration, Mining and Reclamation of Land (25 CFR 177).}

In 1969, the BIA adopted these regulations as a statement of environmental policy with regard to the development of all minerals other than ofl and gas. The stated objectives are to avold, minimize, or correct the negative impacts of mining activities on the environment and to protect public health and safety.

To achieve this goal, the agencles opted to Impose environmental restrictions on permits and leases on a case-by-case basis. The USGS mining supervisor is responsible for Implementing most of the provisions. 
First, the mining supervisor must prepare a technical examination of any proposed lease or other license (e.g., exploration permit). This evaluation must consider measures needed to (1) protect and preserve cultural, ecological, wildlife habitats, and other resources; (2) control flooding, landslides, erosion, toxic materials, air and water pollution; (3) achieve reclamation of lands affected by the activity; and (4) accommodate the local topography, climate, surrounding land uses, population centers, and similarly unique features.

Second, the USGS official recommends to the BIA superintendent any conditions to the standard lease or permit (the "boiler plate" agreement) that may be needed to mitigate impacts identified in the technical examination. If the examination reveals that it is not feasible to prevent landslides, serious sedimentation, and/or siltation of water; contamination of water in violation of state and federal standards; or destruction of key wildlife, cultural, or historical features, then the USGS supervisor should recommend prohibiting activity in that area.

Third, after a lease or permit has been issued by BIA, the USGS supervisor must review and approve the operator's mining plans.

Finally, in conjunction with the BIA superintendent, the USGS personnel inspect the activities to ensure compliance with the lease conditions.

In April of 1977, BIA proposed to amend these regulations to upgrade environmental controls (see later subsection, "Tribal Trust Responsibilities: Proposed Changes"). 
Leasing of Osage Reservation Lands for Oil and Gas Mining (25 CFR 183).

Pursuant to special enabling authority, the Osage Tribe and the Osage Agency directly regulate oll and gas operations on the reservation. Like the USGS guidelines for these operations on other tribal lands, the Osage operating requirements stress the geological factors necessary for efficient extraction and protection of adjoining resources. However, the Osage regulations greatly expand these basic provisions to include:

- Guidelines for use of the surface, including fees for seismic shots; commencement monies held as a credit toward settlement of damages; and fees for tank sites

- Procedures for settling damage claims

- Specific prohibitions on pollution, with guidelines for prevention and mitigating measures to be taken by a11 operators

- Limits on the lessee's use of water

- Guidelines for proper shutdown, abandonment, and plugging of wells.

These regulations only apply to well operations on the 0sage

Mineral Estate.

0i1 and Gas Operating Regulations ( 30 CFR 221). The impacts of oil and gas operations are considered minor relative to coal or mineral mining, and the governing environmental stipulations correspondingly are more brief. These rules emphasize the geological requisites for efficient extraction and the prevention of waste. In general, the regulations address major impact areas, but have not provided standards for compliance or enforcement. For example, Part 221.32 prohibits the pollution of streams and underground 
water sources and damage to the surface, but does not include more detailed specifications. In such instances, the minerals owner has had to rely on compliance general environmental laws such as the Safe Drinking Water Act.

Recently, USGS has taken steps to provide environmental performance standards. For example, in June 1976, USGS issued "NTL-6," a notice to lessees and operators on federal and tribal lands. This notice augments the basic regulations by setting forth more detailed procedures for approval of oil and gas operations. The notice specifies the data and materials that must be submitted by the applicant so that USGS can prepare an adequate environnental review prior to issuing a permit. Operators also are required to submit well data and a surface use and operation plán, and are subject to site inspections.

Also, NTI:-3 sets forth reporting requirements for incidents that may cause pollution or surface damage.

These standards are implemented by USGS through a combination of reporting requirements and in-site inspections. The regulations require inspections of all predrilling and abandonment operations. As a matter of policy, the Conservation Division would like to perform "detailed" quarterly inspections of all producing leases on a quarterly basis, and pollution inspections on a semi-annual basis.

Operating Regulations for Exploration, Development, and Production (30 CFR 231). These regulations govern activities related to exploration, testing, development, extraction, and processing of uranium, oil shale (other 
than in situ processes), and other hard minerals except coal. They apply to all activities authorized under 25 CFR 177.

The regulations consist of five major provisions. The first subsection requires operators to submit exploration and mining plans that include measures to reduce environmental impacts on the physical environment. These mining plans must describe these programs in detail, but there are no standards that must be met. Second, operators are ordered to use mining techniques that allow for maximum efficient recovery, that ensure proper abandonment, and that restrict the extraction of minerals that are soluble in water according to the regulations. Third, the regulations require protection against mine safety hazards, such as fire, gases, and surface openings. Fourth, the regulations stipulate that mine and mill waste disposal must satisfy lease conditions. Finally, the regulations set forth reporting requirements and enforcement mechanisms.

Geothermal Resources Operations on Public, Acquired and Withdrawn Lands (30 CFR 270). These USGS operating regulations focus on the geological engineering requirements for maximum ultimate recovery of the geothermal deposits. Compliance with these regulations reinforces protection of the physical environment. Also, subpart 270.76 requires lessees to submit a report on their compliance with environmental laws and lease stipulations on an annual basis.

By reference to $43 \mathrm{CFR}, 3200$, these operating regulations may not be binding on geothermal developments on tribal lands. 
Tribal Trust Responsibilities: Proposed Changes

In response to the changing conditions and issues affecting mineral development on Indian lands, the BIA has taken steps to revise its current regulations (25 CFR). On April 5, 1977, BIA gave notice of a proposed rulemaking that would modify $25 \mathrm{CFR} 177$ (for minerals other than oil and gas) to include:

- Requirements for detailed environmental and cultural assessments of all proposed minerals contracts

- Requirements for environmental and cultural assessments of proposed exploration and mining plans

- Performance standards for coal mine operations, reclamation, and abandonment

- Provisions for the adoption of reclamation and performance standards for minerals other than coal, oil, or natural gas

- Requirements for annual and periodic reports on operations, backfilling, revegetation, and reclamation.

Key provisions of the revised part 177 ("Plans for Prospecting and Mining on Indian Mineral Lands: Reclamation of Nonmineral Resources") are described below.

Subpart A: General Provisions. The regulations in this subpart apply to the development of all minerals other than oil and gas.

Part 177.4 requires the BIA Area Director to prepare written environmental and cultural impact assessments of proposed contracts. These evaluations 
must address both the impacts of the project and the measures to be taken to counteract the adverse impacts. Among the impacts to be considered are those on:

- Water quality and availability

- Air quality

- Fish and wild1ife

- Existing and planned land uses

- Areas or "items" of historical, ethnological, scenic, or archaeological valve

- The local population (due to dislocation of homes or jobs, an influx of non-Indians, environmental characteristics of the reservation that are religiously and culturally significant to tribal members)

- Any other adverse impacts.

The evaluation of mitigating measures must include a review of:

- Mine reclamation plans

- Measures to prevent and control erosion, subsidence, flooding, etc.

- Measures to protect fish and wildlife habitats

- Measures to ensure health and safety.

The regulations stress that the assessments are to be made avallable to the tribe before the contracts are approved. Also, when warranted, the BIA will prepare an environmental impact statement in addition to these initial evaluations. 
Part 177.5 requires operators to submit exploration and/or mining plans for the joint approval of the GS mining supervisor and BIA Area Director. These plan reviews are similar to the contract assessments, but require project specification on:

- The existing ecology and development of the affected area

- The methods to be used for developing the resources (extraction, conversion and/or transportation)

- The impacts on culturally valuable areas and the steps that will be taken to prevent or reduce the disturbance

- The planned utilization of tribal members in the workforce

- The existing land uses and anticipated land uses once operations are terminated

- The volume of water to be used, the effects on water quality, and proposed control measures

- The measures to be taken to reclaim the land (e.g., revegetation), and to prevent or control air pollution, erosion, fire, flooding, threats to public health and safety hazards and after the operations, and threats to the fish and wildlife habitat.

- A timetable of planned commencement and completion of all operations (including reclamation).

Part 177.6 provides BIA with the option to adopt operating and reclamation performance standards for minerals other than oil and gas.

Finally, Part 177.9 requires more extensive operator reporting than previously existed. First, each year during operations and immediately after cessation of operations, the operator must submit reports to the GS and BIA authorities on the operations performed, the land area affected, and the acreage that has been reclaimed. These reports also must describe the 
reclamation methods that are being used and the work schedule for remaining reclamation activities. Second, operators must submit reports to BIA and GS when grading and backfilling activities required by the mine plan have been completed. The BIA Area Director is authorized to release an appropriate amount of the performance bond if the backfilling and grading are satisfactory. Third, the operator must submit reports to BIA and GS upon the completion of the revegetation activities required by the mine plan. In addition to reviewing these data, the GS and BIA authorities are to inspect and evaluate the site prior to releasing any remaining portion of the performance bond. Finally, operators are required to submit special reports upon either the cessation or abandonment of operations. The regulations stipulate that the BIA Area Director is to advise the Indian mineral owner of each of these four sets of reports.

Subpart B: Coal Operations. These proposed regulations would impose additional requirements for new or modifled exploration and/or mining plans submitted for approval 18 months after the regulations go into effect. Operators will have to comply with performance standards for mining activities and mine reclamation (e.g., specifications for contemporaneous recovery; backfilling; revegetation; air, water, and so11 protection; waste disposal and storage; and other abandonment methods).

IMPLEMENTATION ISSUES AND PROBLEMS

As was seen in the previous section, federal and state governments have acted in the past decade to mitigate the negative environmental impacts of development by providing funds for planning; by legislating performance

1/ In December 1977, BIA adopted the performance standards implementing the Surface Mining Control and Reclamation Act in this subpart. 
standards; and by initiating enforcement measures. The extent to which these controls will meet tribal environmental goals depends on how effectively these broad mandates are implemented. The tribes must determine whether:

- The performance standards are inadequate and need to be strengthened;

- The standards are sufficient, but administration and enforcement need to be strengthened; or

- There are regulatory gaps that should be filled by either tribal or BIA rules and regulations.

Comments made during the site visits have been assembled to highlight the types of difficulties that the tribes have encountered with regard to the standards and enforcement mechanisms currently being used to implement environmental laws. - These inputs are augmented by the findings of studies : by the Government Accounting Office and other federal oversight agencies. Many of the problems identified by the tribes are common to federal resource management in genera1; others, such as the uncertain enforcement jurisdiction under certain acts, are unique to the tribes.

This overview is not intended to be an evaluation of the "adequacy" of existing environmental controls. No definitive conclusions can be presented due to the conflicting value judgments on whether, how, and how much to regulate to achieve environmental goals. Even if the current approach is assumed to be valid, the effectiveness of the controls depends on conflicting variables: the technological ability to detect impacts and to develop abatement mechanisms; the economic costs of pollution control devices, strip mine regulations, and similar measures; the fiscal costs of bolstering the governmental enforcement effort; and the institutional constraints on meeting implementation timetables. In this review, it is assumed that the courts

1 The issue of tribal initiatives to compensate for any deficiencies identified will be addressed later in this section, 
and the policy-makers-national, state, and triba1-will decide whether current environmental controls are "adequate" or "Inadequate." The purpose of the discussion is to identify problems that the tribes would need to address in such an analysis.

The Effectiveness of Existing Performance Standards

At this time, the role and effectiveness of environmental performance standards are still being debated. Critics of such laws as the Clean Air Act and Federal Water Pollution Control Act question their effectiveness in achieving their environmental goals despite the use of very detailed, often rigid specifications. The use of "moving targets" is said to create a deterrent to planning and investment decisions. The agencies responsible for safety regulations (e.g., OSHA) have been criticized for relying on detailed specifications that often are unrelated to health or safety. Conversely, the regulations governing lease management have been challenged for their lack of any performance standards. Exhibits IV-8 through IV- 11 cal1 attention to some of the problems that the tribes identified with regard to the particular types of development and indicate whether the regulations cited in Exhibits IV-2 through IV-6 include performance standards that address the problem. 
EFFECTIVENESS OF EXISTING PERFORMANCE STANDARDS:

OIL AND NATURAL GAS

\section{Water Quality}

Tribes with experience in oil and gas operations cited problems regarding water contamination from existing and abandoned wells that have been maintained improperly.

\section{Air Quality}

One tribe indicated an interest in monitoring the cumulative air quality impacts of gas and oil extracting and processing.

\section{Land Use}

Existing seismic permits and mining leases have not included stipulations that are sufficient to minimize the impacts of access roads and other disturbances related to oil and gas operations.
Two federal laws address the impacts of existing wells: (1) If the reservation's well operations would discharge effluents into a navigable body of water, these operators are required to comply with EPA's oil pollution prevention regulations under the FWPCA; and (2) if any underground injections (including secondary and tertiary recovery) jeopardize sources of drinking water, the EPA imposes controls under the Safe Drinking Water regulations for oil and gas operations.

Although tribes have not been delegated enforcement responsibility under the Clean Air Act, EPA does provide funds for monitoring air quality in heavily impacted areas.

Until NTL-6 was issued in 1976, the manual used by USGS mining supervisors did not include technical standards for their evaluations of the proposed operation. All activities proposed after that date are required to submit detailed site plans that indicate surface activities and their relationship to adjacent communities and developments. 
EXHIBIT IV-9

EFFECTIVENESS OF EXISTING PERFORMANCE STANDARDS:

COAL

\section{Water Quality}

Several tribes have had their water contaminated because of coal mining and related activities.

\section{Alr Quality}

Coal combustion faclities are one of the chief sources of sulfur oxide emissions (SO affects human health, water quality and possibly climate). These processes also produce carbon monoxide, carbon dioxide, nitric oxide, and particulate emissions.

\section{Land Use}

A 1972 study by the General Accounting office (GAO) found that the technical examinations needed to support lease stipulations for surface protection and reclamation had not been done for the tribal leases that they studied.
Operation of mines that discharge effluents into navigable waters must comply with EPA's effluent standards for coal mines and coal preparation facilities under the NPDES. In situ processes, mine wells, tailings piles and other mine-related developments will be subject to EPA's underground infection standards under the Safe Drinking Water Act. The Surface Mining Control and Reclamation Act also regulates the hydrological impacts of coal mines.

EPA has lsoued guidelines for state emfssion limitations for existing sources and new source standards of performance for major coal-burning facllities, such as power generation facilities, coal conversion plants, and coal preparation plants. The 1977 Amendments require such fossil-fuel-burning facilities to meet two standards: an allowable emissions level and a percentage reduction in the emissions from untreated coal. Also, if the facility is to be sited in elther a "nonattalnment" area or a "Class I" or "Class II" area (for the prevention of significant deterioration), other permits are required.

The performance standards now being used for coal developments on Indian lands ( 25 CFR 177 , subpart B). provide detailed standards for coal mining operations and reclamation. Also, the Surface Mining and Reclamation Act will provide tribes with an opportunity to develop and implement standards for coal mine operations. 
EFFECTIVENESS OF EXISTING PERFORMANCE STANDARDS: URANIUM MINING AND MILLING

\section{Water Quality}

Studies of surface and ground water quality in the Grants Mineral Belt in New Mexico have identified contamination problems resulting from uranium mills \& mines.

\section{Air v̂uality}

Preliminary studies of the Grants Mineral Belt in New Mexico have found that gamma radiation exposure exceeded normal background levels in areas near mill sites. This higher concentration may be attributable to wind erosion of the mill tailings.

Land Use

Unless a tribe has included protection measures as lease stipulations, there may be Ifttle oversight over water contamination, tailing piles, reclamation, and other mine management concerns.
EPA standards for underground injections under Safe Drinking Water Act will control in situ processes, mine wells, and tailing piles and ponds. Also, EPA's primary drinking water standards include allowable. limits for radioactivity. EPA has withdrawn its effluent guidelines for uraniun mines and wells under the NPDES program but will be reissuing them.

Further studies are being done to check for compliance with federal and state requirements for tallings stabilization and control programs: By 1980 , operators will have to comply. with EPA's ambient radiation standards for uranium mills.

Also, the Clean Air Act Amendments of 1977 classified radioactive substances (including naturally occurring radioactive materials) as air pollutants. As a result, they will be regulated under ambient air quality standards, as hazardous air pollutants, or under new source performance standards. EPA will determine the nature and form of these regulations within two years of enactment (i.e., August 1979).

There are no technical standards for uranium mining and reclamation activities ( 30 CFR 231 requires submittal of mining plans and provides for the inclusion of lease stipulations, but the regulations do not include performance standards). Studies that will be commissioned 
EXHIBIT IV-10

(Continued)

Land Use (Continued)

A 1974 study of inactive uranium milil sites prepared by the Atomic Energy Commission (now the NRC) found that current programs to control mill tailings are inadequate. under the Surface Mining and Reclamation Act will produce such outlines.

Under existing laws, the regulation from uranium mines is indirect: EPA limits the radiation contamination of surface waters, groundwater, and drinking water; EPA will regulate the air quality and solid

waste Impacts of radioactive substances; MESA controls worker exposure to radiation in underground mines; and $O S H A$ may regulate radiation exposure in the work place, including mines, but only if the mine is related to federal contracts. Uranium mining specifically has been excluded from the scope of the Atomic Energy Act and its implementing regulations (EPA's ambient radiation standards and the NRC's facility licenses). In states that do regulate uranium mining activities (e.g., Colorado and New Mexico), jurisdiction over tribal lands is uncertain. In states that lack the legal authority to regulate uranium mines (e.g., Wyoming, Utah, and South Dakota), the operations are unregulated.

Any license issued by the NRC includes a program to control mill tailings as a condition of the lease. These stabilization plans are based on NRC's environmental review of the project. Some agreement states have regulations specifically for tailings (e.g., Arizona and Colorado); others rely on general radiation standards. However, the AEC study found that the results of these programs varied and often were inadequate. They concluded that it will be necessary to control surrounding land uses until more effective contro1.s can be developed. 
EXHIBIT IV-10

(Continued)

Certain homes on one reservation have been constructed with uranium mill tailings. In 1966, the Public Health Service determined that the use of tailings for construction in Grand Junction, Colorado, was a potential hazard to public health.
State and federal regulations now prohibit the use of tallings material for construction purposes. 


\section{EXHIBIT IV-11}

EFFECTIVENESS OF EXISTING PERFORMANCE STANDARDS:

OTHER AREAS OF CONCERN

\section{Regulation of New Téchnologies}

Many of the projects being considered by the tribes, such as coal gasification, ofl shale, and geothermal development, will be in their first phases of commercialization.

Little is known about the actual environmental and health effects of these new technologies, but concerns have been ralsed regarding the emission of trace metals and trace organics from oil shale and coal gasification or

ㄴ. Ilquefaction plants. Also, although such I facilities may have little direct impact on surface water quality (due to compllance with "zero discharge" standards), ground water may be contaminated by in situ processes and the solid waste generated by the conversion facilities.

\section{Impacts of Prlor Development}

Whereas some tribes have been involved in energy development for 25 to 75 years, most of the environmental laws have been enacted within the past 10 years.
At this time, there are no comprehensive guidelines tallored to coal gasification, ofl shale, or geothermal development. However, EPA and the Energy Research and Development Administration (ERDA) are studying the impacts of prototype projects as a basis for proposing regulations.

Existing regulations prescribe performance standards for new and existing operations, but do not mitigate the impacts of terminated activities. Under the Surface Mining Control and Reclamation Act, funds will be made available for reclaiming abandoned mines. Other special programs may be needed to correct the environmental and heal th problems caused by improperly or ineffectively abandoned mines, wells, and mills. 
EXHIBIT IV-11 (Cont.)

Socioeconomic Impacts of Major Developments

The Navajo Nation experienced a major population influx and relocation of tribal population due to the development of the Black Mesa and Four Corners mines and power plants. For example, it was difficult for the tribe to accommodate the demand for housing, water, sewer, schools, etc., in Keyenta, the town that absorbed most of the tribal population growth. Other tribes that anticipate similar growth pressures have expressed concern about their capability to meet such needs.
The proposed revisions of 25 CFR 177 would require the BIA Area Director to evaluate the impacts of a proposed contract on the tribal population, and on the need for assoclated public facilities (e.g., schools, water, sewer, etc.). However, the actual provision of these services still requires tribal planning and implementation programs. 
The Effectiveness of the Administration and Enforcement of Environmental Controls

The tribes have encountered two major problems regarding the enforcement of environmental laws: (1) the jurisdictional questions that arise from the special legal status of the tribes, a problem that is unique to Indian lands; and (2) shortcomings in the enforcement effort needed to achieve the standards set forth in the laws, a problem common to federal environmental management. The discussion below first reviews the jurisdictional issues with regard to enforcing federal, state, and overlapping regulations on tribal lands. This is followed by highlights of the shortcomings in existing enforcement programs for each federal agency responsible for implementing the regulations (e.g., EPA, Department of the Interior).

Enforcement Jurisdiction for Federal Laws of General Applicability. At this time, the legal status of tribal developments under federal environmental laws is still evolving. Because these statutes are laws of "general applicability," they have been Interpreted as applicable to any operation on Indian lands. The legal complexities arise in Identifying the appropriate authority for administering and enforcing the regulations.

If the federal authority has primary implementation responsibilities nationwide, it will assert that authority on tribal lands. However, some of these regulations rely on implementation by state governments under the auspices and oversight of EPA, the NRC, and OSHA. In these cases, enforcement jurisdiction depends on whether the state has jurisdiction over the tribe pursuant to treaties or state enabling legislation; whether the federal law expressly provides for state jurisdiction on tribal lands; whether the operator is Indian or non-Indian; and other specifics of the 
case. Very few states have jurisdiction over tribal activities, and the environmental laws already enacted have not expressly mandated state enforcement on Indian lands. Where enforcement involves an Indian activity on Indian lands, the EPA, NRC, and OSHA positions are to assert federal jurisdiction. The murkiest legal question is jurisdiction over non-Indian activities on Indian lands. In keeping with legal precedent, their tentative policies are to allow a state to assert jurisdiction over non-Indian operations if the state activities do not interfere or conflict with the tribal government. However, this question must be resolved by the courts before the agencies can firmly decide the enforcement roles of federal and state authorities.

At this time, only five regulations specifically provide for implementation on tribal lands: (1) air quality (tribes may apply for a "Class A" designation to prevent significant deterioration of air quality); (2) water quality (EPA will enforce the National Pollution Discharge Elimination System (NPDES) for Indian Activities on Indian lands); (3) pesticide control (tribes may assume enforcement responsibilities for certifying pesticide applicators); (4) primary drinking water standards (EPA will enforce the standards for Indian water systems and for underground injection); and (5) coal surface mining control and reclamation (tribes may opt to administer and enforce the standards).

\section{Enforcement Jurisdiction for State Environmental Laws. The courts} have not conclusively resolved the issues of federal-tribal-state jurisdiction in civil regulatory matters such as environmental 1aw; but the following trends have emerged from recent regulations and decisions:

- Federal laws administered and enforced by the federal government will be federally enforced on tribal lands. 
- Implementation of federal regulations administered and enforced by the states on tribal lands depends on the wording of the statute; the states' enabling statutes and treaties with the tribes; and whether it applies to an Indian or non-Indian operation. Indian activities are likely to be regulated by the federal government. Jurisdiction over nonIndians is less certain, but states have been allowed to regulate unless it interferes with the tribal government.

- State laws (in civil regulatory matters) administered and enforced by the state generally do not apply to activities on tribal lands. However, the tribes may particlpate in state programs for land-use planning and energy facility siting.

The courts began to draw limits on state jurisdiction over tribal lands with an 1832 Supreme Court ruling that states do not have authority over Indian lands unless Congress expressly dictates otherwise (see Worchester v. Georgla, 31 U.S. (6 Det) 515 (1832). Since then, the issue of statefederal-tribe jurisdiction in civil regulatory matters such as environmental law has evolved into a dichotomy between furisdiction over Indian activities on tribal lands under tribal governments and non-Indian activities on Indian 1ands. The major rulings are based on the following laws and rulings:

- States may assert jurisdiction over tribes if authority is granted in the state enabling legislation, treatles, or similar statutes. One of the only states that has such authority is Oklahoma, but even this is Iimited (e.g.; the state has no jurisdiction over the Osage Mineral Estate).

- 25 CFR 1.4 states that with few exceptions: "none of the laws, ordinances, codes, resolutions, rules, or other regulations of any state or political subdivision thereof limitIng, zoning or otherwise governing, regulating, or controlling the use of development of any real or personal property, Including water rights, shall be applicable to any such property lease from or held or used under agreement 
with and belonging to any Indian or Indian tribe, band, or community that is held in trust by the United States or is subject to a restriction against alienation imposed by the United States."

- Public Law 280 (1953) mandated certain states to extend criminal and civil jurisdiction over designated reservations and allowed other states to assume similar responsibility if the tribes consented. However, the courts recently held that the law grants jurisdiction over private civil litigation, not general civil regulatory powers in areas such as economic and environmental regulation. See Bryan v. Itasca, U.S. _, 96 S. Ct. 2102, 2105 (1976). Similarly, the courts have ruled that state zoning laws represent an "encumbrance" of the tribes' real property, and hence denied the state the power to apply its zoning regulations to tribal property. Santa Rosa Band of Indians v. King's County, No. 74-1565 (9th Cir. Nov. 1975) cert. denied, 1977.

- Section 231 of Title 25 of the U.S. Code allows the Secretary of the Interior to permit states to enforce sanitation and quarantine regulations and to inspect health and educational conditions on Indian lands. However, the Department has ruled that federal rules and regulations must be issued before a state can exercise such authority. This principle was upheld in a recent denial of a writ of certiorari. Since no regulations have been promulgated, Section 231 powers remain dormant.

- Although state prerogatives have been constricted by these laws and rulings, various court cases have narrowed the focus of their limitations to Indians living on tribal lands under tribal. laws. See McClanahan v. Arizona

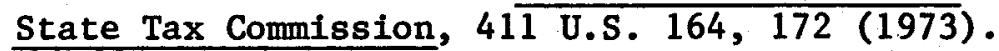
This leaves open the question of state jurisdiction over non-Indians. One possible criterion for state regulation of these activities was established in the case of Williams v. Lee, 358 U.S. 117 (1959) in which the courts denied state authority where it would infringe on the "rights of reservation Indians to make their own laws and be ruled by them." 
If state environmental laws do not conflict with tribal laws and self-govermment, then state jurlsdiction may be appropriate. However, no binding resolution has been reached on this issue.

Private communications with the legal staffs of the 10 states that have CERT tribes within their boundaries confirmed the tendency toward state jurisdiction over the activities of non-Indians on Indian lands. New Mexico assumes authority over the mining and reclamation activities of non-Indians. The Arizona courts recently ruled that the state does not have enforcement jurisdiction over Indian activitles on reservations for the purpose of OSHA; the question of jurisdiction over non-Indians still is before the courts. Both Montana and North Dakota disclaim jurisdiction over Indian activities on tribal lands, but Montana w11 enforce state reclamation laws on ceded 1ands. (Ceded lands are those to which the Crow Tribe owns the mineral rights, and non-Indians, the surface rights..) State regulations regarding energy facllity siting (e.g., Montana, North Dakota, New Mexico) and landuse planning generally provide for tribal participation. Participation In statewide efforts, however, has been limited.

Enforcement Jurlsdiction under Mixed Ownership of Mineral and Land

Rights. Some tribes that have "checkerboard" patterns of land ownership regarding minerals have encountered difficulties in the enforcement of USGS environmental regulations when the mining unft or producing field contains both tribally and publicly owned rights. Extsting BIA-USGS regulations do not Include procedures for folnt federal/state enforcement. However, under the Surface Mining Control and Reclamation Act, procedures for such cooperation should be implemented. 
Overlap in Enforcement Jurisdiction. Both EPA and USGS are responsible for enforcing oil and gas effluent controls. To date, the two agencies have not entered into a formal "memorandum of understanding," to clarify or coordinate responsibilities, but they do work jointly on major spills under the National Oil and Hazardous Materials Pollution Contingency Plan (40 CFR 109.4).

Similarly, USGS has been responsible for enforcing lease stipulations regarding worker safety, a function now also performed by MESA and OSHA. Again, responsibility has not been formally assigned. Consequently, all three have continued to enforce the standards under their purview.

Finally, there are no formal procedures to coordinate federal and state activities where jurisdiction overlaps (e.g., for reclamation standards in New Mexico).

General Problems in Enforcement of EPA's Laws of General Applicability. EPA's task of administering and enforcing highly technical and detailed standards for thousands of highly diverse polluters has been difficult to achieve within their mandated timetables. For example, approximately 10 percent of the stationary sources have either been found to be in violation of air quality emissions standards or are behind their compliance schedule. Such difficulties arise from several problems, including the complexity of the standards, 1imitations of measuring and monftoring techniques, and understaffing.

These technical dilemmas may best be 1llustrated by the 1976 findings of the GAO regarding implementation of the Federal Water Pollution Control Act: 
- As of June 30,1975 , EPA and/or states with NPDES authority had issued 36,800 discharge permits, but this was only $69 \%$ of the 33,300 Industrial and 19,700 municipal applicants. Furthermore, the courts have advised EPA to issue permits for nonpoint sources-appropriately 1.8 million animal feedlots, 100,000 stormwater run-off sources, and many others.

- Most of the Industrial permits were not based on "final" effluent discharge guidelines because the standards had not been issued or were not applicable to a particular industry.

- Legal challenges to the standards have diverted technical staff from enforcement activities to preparing legal defenses.

- About $23 \%$ of the 2,000 major industrial permits Issued by EPA requested adfudicatory hearings. These delays may make it difficult for the. applicant to meet the 1977 discharge standards.

- GAO found that from November 1974 through January $1975,1,492$ holders of Industrial permits were not adhering to their compliance schedule or were not submitting required reports.

- Municipalities may not meet the 1977 standards primarily due to the slow pace of disbursement of federal funds for the construction of wastewater treatment facilities.

When the EPA has been confronted with such enforcement problems, the agency has had to weigh the impacts of not meeting the environmental standards against the Impacts of requiring compliance (e.g., plant shutdown). Under the Clean Alr Act and FWPCA, a commonly used alternative has been to adjust the performance standard and/or fmplementation timetable on a caseby-case basis. However, the Clean Air Act Amendments of 1977 have authorlzed EPA and/or the state authoritles to levy "noncompliance penalties." These will be assessed on the quarterly equivalent of the costs of compliance (e.g., capltal costs, debt service, operations, maintenance) minus 
any expenditures made during the quarter for the purpose of complying with the standards. This use of a noncompliance penalty may set a precedent for other environmental statutes.

Finally, EPA's inspections and enforcement efforts have been hampered by inadequate staffing. Since its creation in 1970 , the total number of staff has increased by less than 500 persons despite the legislative mandates that have been added in these years.

General Problems of the Department of the Interior Lease Management Program. Studies of the Department of the Interior's lease management program have reached three common conclusions: (1) that the prerogative to condition leases with environmental stipulations provides the tribes with an effective control mechanism; (2) that the Department should adopt technical standards for project review and inspections; and (3) that enforcement (inspection, compliance fines, etc.) is weak and should be strengthened. A detailed evaluation by NASA (1974) of the Geological Survey's onshore lease management program identified several enforcement problems :

- From 1972 through 1974, the number of oil and gas inspections averaged $35-40 \%$ of the number required to meet the "standards." In 1973, the actual inspections were $37 \%$ of the standard nationwide; less than $60 \%$ in the Southern Rocky Mountain Region; and less than 20\% in the Northern Rocky Mountain Region. Similarly, actual inspection of mine operations was less than $50 \%$ of the standard.

1/ Onshore Lease Management Program Study for the U.S. Geological Survey, by NASA, December 1974; Indian National Resources - Part II; Coal, O1I and Gas. Better Management Can Improve Development and Increase Indian Income and Employment, Government Accounting Office, March 1976. 
- The time spent on an 011 and gas inspection averaged 26 minutes in 1973 (including travel time); of this, from 10 to $23 \%$ was spent in the field. The study concluded that "many inspections are superficial."

- Between 1970 and 1974 , the rate of formal enforcement activities (e.g., fines, lease cancellations, shut-ins) was significantly lower than that for offshore leases. Warnings were issued for $8 \%$ of the operations inspected; $.5 \%$ were issued suspension orders. Only $1.3 \%$ of a11 lessees were fined; the average fine in the Central Region was $\$ 42$ (all of the CERT tribes are in this region). Approximately $1 \%$ of the leases were shut-in, compared with $12 \%$ of the offshore leases.

- Most inspections are informal, such as telephone calls and informal notes. Corresponingly, inspection records lack substance, rarely Indicate follow-up on the operator's compliance, and are not used by the higher eschelon administrators.

The analysts attribute most of these difficulties to the Survey's manpower and management position. For example:

- "We do not believe the Diviston can possibly accomplish what we perceive as its legal obligation with anywhere near the present level of manpower .... [a] large increase in the existing manpower level would be required for minimum reasonable enforcement and supervision; unless substantial blocks of work are performed by contractors." According to the GAO, the Central Region will still be $35 \%$ effective in its oil and gas operations despite an increase of 40 positions in fiscal year 1976 .

- The staff are dedicated and hardworking, but morale was low due to the manpower shortage, workload increases, and inadequate support for enforcement actions from the agency, $O M B$ ? and the Justice Department. 
- The general attitude of the Department has been that the "burden of proof" for compliance with regulations rests with the government. The study group recommended changing this policy and related procedures, and to retrain fleld staff accordingly.

Since the time of the NASA study, the Conservation Division has taken several actions to correct for the deficiencies that were identified with regard to their inspection and enforcement programs. First, staff are being increased now that the operating regulations for mining on federal lands require at least quarterly inspections. The coal mine inspections staff has been increased to meet this level. This may have a positive effect on staff avallability for inspection of mines on Indian lands even though the BIA regulations do not stipulate the frequency of Inspections. The 011 and Gas Division Inspections staff has been increased since 1975, but they are not achleving their desired level of performance of quarterly Inspections of active leases. Second, regulations for coal and other mining activities have been amended to provide for the 1ssuance of formal enforcement orders. Similar provisions for oll and gas operations still are being reviewed by the Division.

\section{General Problems in Enforcing MESA Regulations. A recent GAO} study of MESA's noncoal program Identified several defictencies in the agency's enforcement program. One critical shortcoming is the apparent lack of adequate enforcement authority, but this problem may be remedied by the proposed revisions to the Acts. GAO cited the variation in the quality of Inspections, and recommended that MESA strengthen its training and management control programs. Finally, the oversight agency also suggested that greater emphasis be put on health-related conditions in the mines. 
General Problems In Enforcing the Nuclear Regulatory Commission's

Regulations. A 1974 AEC study on the regulation of uranium mill tailings recomended Increased Inspections and monitoring of active and inactive mills to guarantee that the desired results of stabilization and control plans are achieved. Also, NRC reviews of agreement state programs have found that budget and other Iimitations may weaken some state programs. Whereas the NRC and states can increase their enforcement of licensed facilities, they do not have authority to monitor and inspect the mill sites once the license has been terminated. However, if a serious radiation threat has been identifled, the NRC can respond. Also, seven states have acted to fill the post-license vold authorizing special state control over mills no longer bound by the permits.

\section{Genera1 Problems in Enforcing OSHA Regulations. Although OSHA} has a large enforcement budget and staff, critlcs have argued that three factors IImit the agency's effectiveness. First, despite the size of the fleld staff, the rate of Inspections is very low. The "average" plant can expect to be Inspected once every 27 years. Even OSHA's "target industries," large firms that characteristically have high accident and personal injury rates, have had only a 10 percent chance of belng inspected in a given year. Second, inspections may not detect all possible violattons, Emphasis has been put on serious safety hazards and on basic provisions of the regulations. For example, in 1973,22 of the 4,400 standards accounted for 42 percent of all of the violations cited. Finally, fines for violations are very low. The average fine per violation was $\$ 25.00$ in 1975 . 
In 1 ight of the typical costs of complying with all of the OSHA regulations, these factors reduce any incentive to meet standards. For example, a recent analysis found that a large firm would have to expect only 400 citations for willful violations per year before the costs of the fines would exceed the costs of meeting the standards. The new Administrator of OSHA has recognized these shortcomings and has taken steps to streamline the regulations. by putting greater emphasis on performance rather than specifications, and on health as well as safety conditions.

TRIBAL OPTIONS TO STRENGTHEN ENVIRONMENTAL CONTROLS

As stated in the introduction, existing environmental laws have been developed to achieve a balance among conflicting objectives on development. Tribal dectsion-makers are faced with the difficult task of determining whether the needed balance exists and, if not, what steps must be taken to achieve 1t. In cases where existing mechanisms are deemed inadequate, tribal leaders may decide elther to deny development or to augment the current programs with special tribal controls. The purpose of this subsection is to call attention to the general issues that must De addressed to implement such supplemental controls.

The scope of this discussion has been limited to an overview of the following implementation tasks:

(1) Decide whether and how to control the environmental impacts of development

(2) Identify the alternative control mechanisms avallable to the tribe 
(3) Develop the standards and procedures needed to achieve the goals

(4) Determine the tasks and resources needed to implement the control measures.

Because of the technical complexity, political controversy, and general uncertainty assoclated with a program to implement environmental controls, each of these four tasks will require thorough legal analysis, economic assessments, studies of the environmental needs of the reservation, and a policy consensus on the tribe's approach to environmental regulation.

\section{Tribal Policy Decisions}

Any program or regulation undertaken will be based on a policy decision made by the tribal leadership on whether tribal standardsetting and/or enforcement capability are warranted. This evaluation process should follow steps similar to those discussed in Volume II regarding implementation of a general resource management program.

First, the evaluation should begin with a clear understanding of the tribe's environmental goals and how all types of development would affect those goals for each impact area (e.g., air, surface water, ground water, solid waste, land use). Tribal leaders must declde which strategies are needed to accomplish each of these goals, and what is needed to implement the strategies. For the purposes of environmental controls, this mav consist of performance standards and an enforcement capability. Again, tribal leaders should determine what minimum standards and enforcement are needed to accomplish the goals.

Second, the tribe must evaluate the effectiveness of current standards and enforcement measures. Materials such as those in the 
preceding subsections may be used in this assessment. These evaluations should be done on the existing controls for each impact of each type of resource development. For example, using Exhibit IV-9, tribal leaders should study the effectiveness of EPA and DOI's programs for controlling ground water contamination from coal mining; EPA's programs for controlling air emissions from electric power generation facilities; and DOI's programs to ensure reclamation of strip-mined areas. Where weaknesses are identifled, it is important to distinguish between the adequacy of the standards and the adequacy of the enforcement effort. These evaluations should result in a directive to the tribal staff to analyze in greater detall the major alternatives avallable to the tribe.

Finaliy, if tribal leaders determine that elther the current standards or enforcement efforts need to be upgraded, then alternative methods and the resources required to implement them must be evaluated. Tribal leaders should select programs on the basis of at least three criteria: the tribe's legal authority to implement them; their effectiveness in achieving environmental goals; and the staff and financial resources needed to implement them. The materlals below discuss factors that may be considered in these evaluations. Alternatively, if the tribal leadership determines that existing controls provide sufficient protection, then no further effort or expenditure would be needed.

\section{Alternative Control Measures}

Each of the alternative environmental control measures will be derived from a legally recognized tribal authority to set and enforce such standards. The primary sources of such authority are: (1) contract conditions (e.g., stipulations on leases, rights-of-way permits); 
(2) tribal ordinances (e.g., land use, taxation codes); and (3) any authority delegated to the tribe by the Congress, Correspondingly, most tribal programs fit one of these three classifications.

Contract Conditions. ${ }^{1 /}$ Lease, permit, or contract stipulations may provide tribes with the most definitive legal justification for adopting and enforcing environmental controls. Numerous statutes have authorized tribes to lease and/or negotiate contracts for the development of their mineral resources. In conjunction with the Secretary of the Interior, the tribe may impose any contract terms that it feels are necessary, including environmental standards. Such stipulations may be enforced by both the DOI and/or the tribe itself.

Performance standards may be inserted at two different junctures: in the approval or reapproval of the contract, and in the approval of the more detailed operating plans. As was discussed in an earlier subsection, the trust regulations for minerals development set forth minimum environmental standards for each type of resource (e.g., 25 CFR 171, 177 , and 182). The regulations require environmental assessments of and stipulations for all proposed projects and contracts. In practice, the specific terms that have been included in contracts and operating plans have been vague or general in nature. Certain tribes, such as the Navajo and Laguna, have imposed more detailed specifications (e.g., requiring power plants to reduce sulfur emissions by 90 percent). In some cases, tribes such as

1/ As used here, the term "contract" refers to any permit, lease, or contract related to the development of tribal energy resources.

2/ It is important to note that this option is avallable only when the tribe enters into or renegotiates a contract. Therefore, this approach may not be effective in controlling the impacts of many of the existing energy developments on a reservation. 
the Navajo and Crow have codified the standards so that they will apply to all future permits or leases (e.g., the Crow coal mining and reclamation code and the Navajo minerals code).

There are several mechanisms available to enforce environmental contract terms. First, the DOI is required to monitor and enforce any contract provision, and may assess fines and issue enforcement orders to do so. Second, the regulations require the operator to submit performance bonds that should compensate for any shortcomings in the environmental management of the development. Third, the regulations emphasize that the tribes may utilize all remedies available to them as mineral owners in contract or other applicable law. For example, the Navajo tribe has imposed a fee on any sulfur emissions from electric power generation facilities that exceeded the level permitted under the terms of the contract. 1 /

One additional contract term that may offer a tribe another means to strengthen environmental controls is a provision for tribal participation in the management and operations of the venture. Participation may enable tribal inputs to be utilized and tribal decision-making responsibilities to be assigned in the overall environmental strategy of the project planning, as well as in the day-to-day operations. However, it should be noted that environmental concerns will be only one set of many factors that will be weighed by tribal participants. Therefore, this strategy may have an uncertain effect on the quality of environmental controls.

1/ This tribal action has been opposed by the companies. The matter has not been finally decided by the courts. 
Tribal Ordinances. Tribal governments may adopt ordinances or codify standards as an exercise of their legislative powers. Under the 1934 Indian Reorganization Act (IRA), most tribes were authorized to adopt constitutions and by-laws that enumerate the tribe's powers of selfgovernment. The Act requires Secretarial (DOI) approval of these enabling laws. Non-IRA tribes have similar prerogatives, but follow different procedures for obtaining Secretarial approval.

There are numerous uncertaintles assoclated with using ordinances as a basis for setting and enforcing environmental standards. For example, with regard to standard-setting, the Secretary of the DOI has asserted approval power over ordinances and amendments as an extension of the original IRA mandate and of basic trustee prerogatives. $1 /$ Therefore, any standards proffered by a tribe first must be approved by the DOI. Also, at this time, the applicability of tribal ordinances to all activities on the reservation has not been decided conclusively. Tribal ordinances clearly govern the activities of tribal members within the reservation, but jurisdiction over non-Indians is uncertain.

Similarly, tribal opportunities to enforce standards may be Iimited under this approach. To date, the Secretary has ruled that ordinances allow a tribe to exclude certain activities (e.g., prohibit certain land uses), but do not enable tribes to punish or fine non-Indians. It should be noted, however, that certain tribal ordinances include penalties, but do not explicitly state their applicability to non-Indians. Instead, this question is taken to the courts for settlement. At this time,

1/ See "Legal Analysis of the Indian Reorganization Act of 1934," in Report on Tribal Government, American Indian Policy Review Commission, July 1976, p. 213. 
the question of tribal civil and criminal jurisdiction over non-Indians, especially where the regulation is concurrent with state laws (as is the case with numerous environmental laws), has not been decided by the courts.

Congressional Delegation. If the Surface Mining Control and Reclamation Act of 1977 is indicative of future trends in delegation of authority for envirommental programs, then tribal governments may begin to have standard setting and enforcement responsibilities similar to those exercised by state governments. ${ }^{\prime}$ ' Such express delegation by the Congress should establish the tribes' jurisdiction over non-Indian operators. 21

Without explicit Congressional delegation, it is unclear whether tribes can assume such responsibilities. For example, if, through an administrative ruling, tribes were assigned the status of a "state" for the purposes of the Clean Air Act, the tribal government must demonstrate its legal authority to adopt and enforce emission standards and limitations (40 CFR 51.11). Under both the Federal Water Pollution Control Act and the Safe Drinking Water Act, the tribe must demonstrate its statutory authority to adopt the standards, implement permit procedures, and assess civil and commercial penalties and remedies for violations of the regulations (see 40 CFR 124.73 and 40 CFR 146.10 respectively). Although such an administrative

1/ As noted in the second subsection, Section $710(a)$ of the Act requires the Secretary of DOI to propose legislation that would enable tribes "to elect to assume full regulatory authority over the administration and enforcement of regulations of surface mining of coal on Indian lands."

2/ The Supreme Court has ruled that Congress can delegate regulatory authority over non-Indians in United States V. Maguire 419, U.S. 557. 
ruling could eliminate concurrent state/tribal regulations, the question of tribal furisdiction over non-Indians must be resolved before tribes could clearly prove their eligibility to assume the regulatory responsibilities.

\section{Program Standards and Procedures}

After tribal leaders have chosen an approach to environmental controls, the next step is to develop the standards and procedures that are needed to accomplish the environmental goals. Both the standards and procedures must be formally adopted either in a contract or a tribal law before it can be legally binding on developers. In order to tallor the enviromental program to tribal needs, the specific standards and program components should be developed on a case-by-case basis. However, if the experience under existing environmental laws is a useful guide, such codes should include at least the following three elements: - (1) implementation procedures that are administratively flexible but sufficient to meet the due process and other requirements of law; (2) environmental quality targets to be achieved by the program for the reservation as a whole; and (3) provisions to control the environmental impacts of individual developments.

Implementation Procedures. The procedures used in most environmental regulatory programs are needed to achleve one of three major purposes:

(1) to establish control over the environmental impacts of specific projects through the establishment of permit procedures; (2) to enforce the standards; or

1/ These are in addition to having adequate legal authority to adopt and enforce the standards. 
(3) to adopt performance standards. The key features of existing procedures are as follows.

First, in keeping with the legal foundations of these programs, most environmental control measures are implemented by means of permit procedures. As noted above, the development of tribai minerals involves exploration permits, leases or simllar contracts, and siting permits. Depending on the type of project, it also may require a mining and reclamation permit, NPDES or underground injection control permit, air emissions permit, hazardous waste disposal permit, and so forth. Likewise, tribal ordinances, notably those for land use and zoning controls, typically require permits before development. will be allowed.

Second, procedures are needed to guide monitoring and enforcement activities. Federal regulations set forth procedures to be followed for the submission of reports, data collection and review, on-site inspections, and simllar oversight practices. Procedural guidelines also must provide for adjustments to permit stipulations, enforcement actions, and appeals of decisions or punitive measures.

Third, federal regulations also include procedures that guide the manner in which standards are adopted and administered. For example, under most regulations, the programs must include procedures. for public participation in developing the standards and for public notice of all major permit applications and decisions.

Performance Goals. Existing environmental programs begin with policy goals for each aspect of environmental quality (e.g., air quality, water quality). 
Programs and regulations are designed to achieve these ambient standards. $\underline{\text { I }}$ Under current laws, these targets range from very general policy declarations to (relatively) detailed performance specifications. For example, the Federal Water Pollution Control Act measures are intended to achieve water quality "which provides for the protection of fish, shellfish, wildlife, and provides for recreation in or on the water by $1983^{\prime \prime}$ (33 U.S.C. 1251 (a)(2)). The Clean Air Act requires EPA to define air quality in terms of the relationship between measured levels of certain designated pollutants and the public health and welfare. Alternatlvely, like many land-use programs, the Surface Mining Control and Reclamation Act Includes performance standards for protecting local hydrologlc systems (water quality), culturally and environmentally sensitive areas, and so forth. Such criteria are needed to monitor the effectiveness of the individual control measures.

Permit Stipulations. Environmental regulations characteristically require each permittee to comply with stipulations tallored to the impacts of the individual project. Compliance with these conditions should be sufficient to achieve the ambient environmental quality targets. At this time, permit stipulations follow one of three general patterns:

(1) Standards for the siting, design, and operation of a particular pollution source to limit effluents or other impacts. Almost all existing environmental programs are based on such specifications. 27 such

1) "Ambient standards" set criteria for the quality of the general environment (e.g., cumulative air quality in an area or cumulative water quality of a river). "Effluent or emission standards" set the criteria for pollution from specific sources.

2/ See, for example, the emissions standard limitations for point sources in the Clean Air Act, effluent 1imitations under the FWPCA, and similar standards in the Safe Drinking Water Act and Resource Conservation and Recovery Act. 
standards typically begin with industry-wide guidelines based on technologica1, economic, and scientific factors. Subsequently, these broad specifications are modified to reflect the unique characteristics of the particular facility. They generally are enforced by means of civil or criminal penalties.

(2) Fees on the emission or discharge of a particular pollutant. None of the environmental programs in the United States currently rely on such economic incentives. Under this approach, the regulations would set a fee for a unit of a particular emission (e.g., cents/pound of emissions of sulfur) based on such factors as the "environmental costs" of the pollutant to public health and welfare, the costs of clean-up, or other selected economic measures. The polluter then pays the fee according to the volume of the pollutant that is discharged.

(3) A combination of standards and penalties. Under this strategy, the permittee is required to meet certain performance standards (e.g., a percentage reduction in emissions) and must pay a penalty for any emissions or effluents in excess of the level stipulated in the permit or contract $1 /$ The level of the penalty is at the discretion of the regulators, but generally is related to the costs of the most appropriate control technology. The Clean Alr Act Amendments of 1977 include such measures, and the Navajo sulfur emissions fee parallels this principle.

\section{Resource Requirements}

When developing environmental controls, the tribe also must determine what activities and resources are required to implement the program. It 15 recommended that interested tribes refer to Part I of Volume II for data and a framework that may be useful in identifying these needs. As indicated in that volume, these evaluations should include the following tasks:

1) The penalty differs from the "fees" discussed above in the following way: The "fee" would be levied on all emissions; the penalty would apply only to emissions in excess of the level allowed by: the standards. 
(1) Determine what support activities are needed either to prepare the standards (for inclusion in the contract, ordinance, or implementation plan) or to monitor and enforce compliance.

(2) Estimate the staff and funding resources needed to implement an activity. This involves est Imating workloads, the skill levels needed, and the direct and indirect costs of the program.

(3) Design the implementation program. This involves selecting the activities to be undertaken, appropriating necessary funds, and integrating the environmental program into the existing tribal government structure:

Volume II provides a sample framework for performing these evaluations and provides data on the tasks, and staffing and fundjug requirements associated with minerals management. Although those materials do not provide specifications for programs in air quality, water quality, solld waste management, etc., the framework used may be appropriate for developing an environmental program. Several summary exhibits from Volume II are repeated here to illustrate the types of analysis that should be performed. $1 /$ Exhibits IV-12 through IV-16 constitute a series of supporting analyses for the selection of programs. Data on the activities and resource requirements of specific environmental programs should be avallable from EPA and the corresponding state agencies. Finally, to illustrate one approach toward integrating these activities into the tribal government the organizational format for management model III (In which a tribe Implements a code or ordinance) is repeated here as Exhibit IV-17.

1/ These exhibits are from Appendix B in Volume II. 


\section{EXHIBIT IV-12}

\section{CONSOLIDATED PROGRAM SUMMARY}

TITLE: RESOURCE PLANNING MANAGEMENT

ESTIMATED BUDGET CEILING: $\$ \$ 60,000$

\section{Long-Range Goals and Objectives}

- Develop energy resources according to policles that account for tribal economic, environment, and cultural goals

- Minimize physical environmental Impacts of existing and new ofl and gas operations

- Maximize revenues from existing and new oil and gas operations

Level of Output Needed to Accomplish Objectives

- Tribal energy policy guidelines

- Performance standards for operations

- Supervision inspections to ensure compliance with performance standards

- Audits of lease accounts to ensure accuracy in royalty payments

- Multiple-use plans that include ofl, gas, and other mineral development options Current Methods of Accomplishing Objectives

- GS performance standards for operators

- GS reporting requirements for all operators

- GS inspections and audits of producing leases

- Tribal comprehensive economic development plans (OEDP) and land-use plans (HUD 701), for other than minerals issues 
EXHIBIT IV-12 (Cont.)

\section{Proposed Programs and Accomplishments}

- Create a minerals-related department within the tribal government

- Hire one full-time and one part-time petroleum engineer to perform on-site inspections so that "minimum" level is achieved (supplement GS effort)

- Hire one part-time accountant to perform post-audits of producing oil and gas lease accounts (supplement GS efforts)

- Include minerals component in tribal economic and land-use plans by year 2 , adopt energy policies

\section{Resource Requirements}

Staff years

Personnel costs

Non-personnel costs

Total cost to tribe

\section{Year 1}

2.1

$\$ 69,224$
Year $2 \quad$ Year 3

2.0

$-$

$\$ 61,572$ 
EXHIBIT IV-13

PROGRAM EVALUATION SUMMARY

TITLE: Resource Planning and Management

PROGRAM AREA: Supervise 011 \& Gas Operations

LEVEL OF EFFORT: Minimum

Activity Description

- Performance standards for operations

- Various inspections of producing leases, inspections of pre-drilling and abandonment operations (See Exhibit II-8)

Objectives to be Accomplished

- Ensure "maximum ultimate recovery"

- Protect the physical environment

- Enforce all regulations

Workload Tables

Per Exhibit III-8:

Task

predrilling reviews

detailed quarterly inspections semi-annual pollution Inspections

semi-annual equipment verification surface compliance check
Year 1 Year 2 Year $3 \quad$ Year $4 \quad$ Year 5

Units

\#exploratory wells

\#development wells

\#producing leases

\#producing leases

115

\#producing leases

\#producing leases 


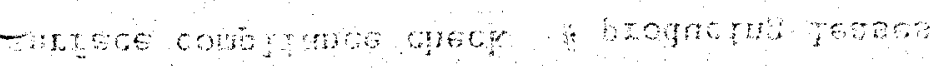

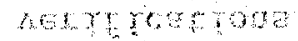

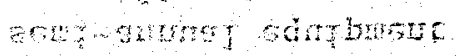

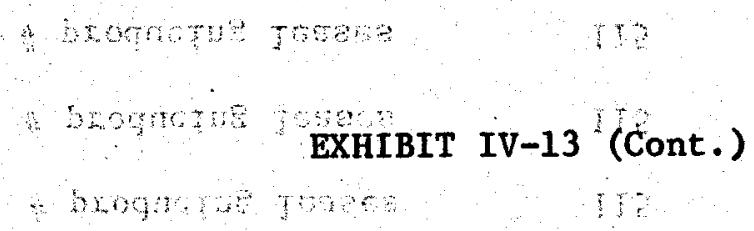

Resource Requirements

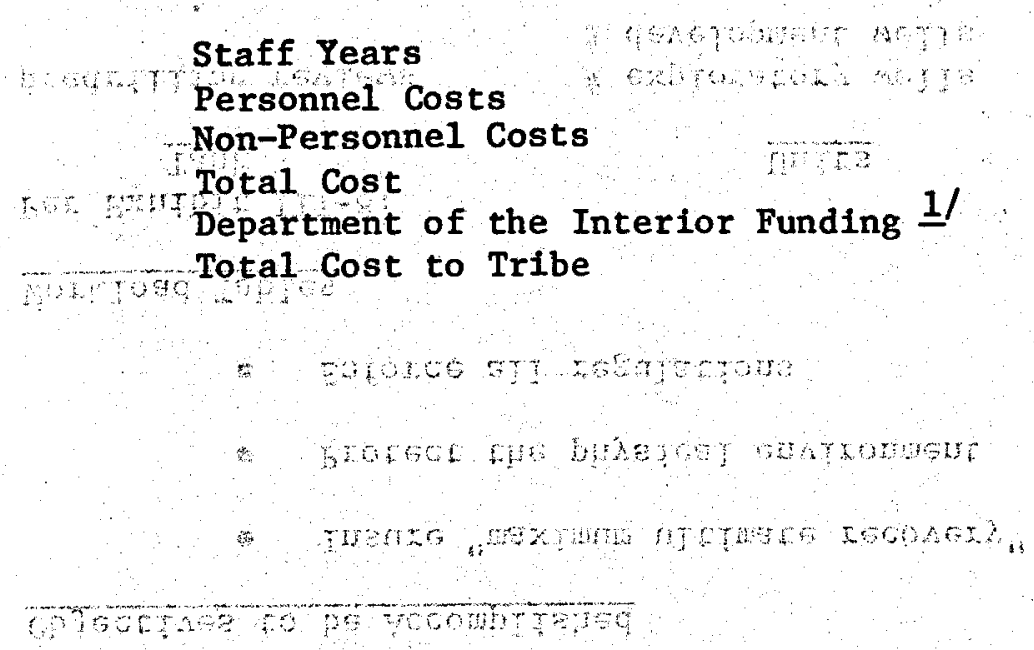

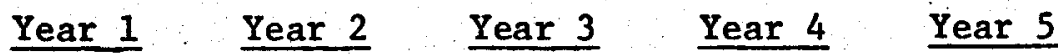

\subsection{6}

$-$

$\$ 154,124$

$\$ 100,561$

$\$ 53,563$

If This "funding" represents the average cost of the activities performed by DoI at no cost to the tribe.

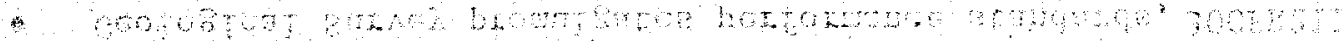


TITLE: Resource Planning and Management

PROGRAM AREA: Supervise Operations

LEVEL OF EFFORT: Current

Activity Description

- Geological Survey promulgates performance standards, 30CFR211

- Geological Survey petroleum engineers inspect producing lease operations

- BIA serves as liaison between the tribe and GS

Objectives to be Accomplished

- Insure "maximum ultimate recovery"

- Protect the physical environment

- Enforce all regulations

Workload Tables

Per Exhibit III-8:

Task

Units

\begin{tabular}{|c|c|c|}
\hline & & oad Unt \\
\hline ear 1 & Year 2 & Year 3 \\
\hline
\end{tabular}

predrilling reviews

\# exploratory wells

\# development wells

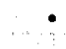

•

-

detailed quarterly

\# producing leases

inspections

semi-annual pollution

\# producing leases

115

inspections

semi-annual equipment

\# producing leases $\quad 115$

\# producing leases 115

verification

surface compliance check \# producing leases

113 


\section{EXHIBIT IV-14 (Cont.)}

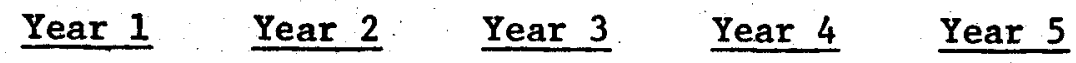

Resource Requirements

Staff Years $1 /$

Personnel Costs

Non-Personnel Costs

-

Total Cost

Department of the Interfor Funding $2 / \$ 100,561$

Total Cost to Tribe

0

1) Staff-years are based on the workload data from Exhibit III-11 multiplied by the level at which each one is currently performed by GS.

2/ This "funding" represents the average cost of the activities performed by DoI at no cost to the tribe. 


\section{EXHIBIT IV-15}

PROGRAM EVALUATION SUMMARY.

TITLE: Resource Planning and Management

PROGRAM AREA: Supervise 011 \& Gas Operations

LEVEL OF EFFORT: Improvement

Activity Description

Perform minimum level, but increase detalled inspections of producing leases to monthly, and perform pollution inspections quarterly.

Objectives to be Accomplished

Strengthened enforcement

Workload Tables

See Exhibit III-1I

$\underline{\text { Year } 1}$ Year 2 Year $3 \quad$ Year $4 \quad$ Year 5

Resource Requirements

$\begin{array}{lc}\text { Staff Years } & 7.96 \\ \text { Personnel Costs } & - \\ \text { Non-personnel Costs } & - \\ \text { Total Costs } & \$ 275,765 \\ \text { Department of the Interior Funding } 1 / \text { I } & 100,561 \\ \text { Total Cost to Tribe } & \$ 175,004\end{array}$

1/ This "funding" represents the average cost of the activities performed by DOI at no cost to the tribe. 
EXHIBIT IV-16

ACTIVITY EVALUATION SUMMARY

Subject

: Resource Planning and Management

Program Area : Supervise 011 \& Gas Operations

Activity

: Perform 011 and Gas On-Site Inspections

Long-Range Goals and Major Objectives

- Minimize physical impacts on the environment, especially water quality impacts

- Maximize revenues by ensuring maximum efficient recovery

Minimum Leve1 of Output Needed to Accomplish Objectives

- Inspections of old pre-drilling and abandonment operations

- Quarterly "detailed" inspections of al1 producing leases

- Semi-annual pollution inspections

- Performance standards for all operations

- Standards for determining violations of regulations and levying penalties

Current Methods of Accomplishing the Objectives

- Geological Survey performance standards, 30 CFR 221

- Geological Survey district engineers perform on-site inspections for FY 1978 pre-drilling anc abandonment inspections have a $100 \%$ performance rating, "detailed" inspections, about a $25 \%$ rating

\section{Alternative Methods}

- Adopt tribal ordinance setting forth performance standards for operations and assessment of compliance

- Hire tribal petroleum engineer to perform "detailed" inspections

- Report any instances of probable violations to BIA Superintendent for action by GS Supervisor. 
EXHIBIT IV-16 (Cont.)

\section{Alternative Levels of Effort}

- Minimum : Supplement DOI "current" activities to achieve "minimum" level of inspections by hiring a tribal petroleum engineer to perform inspections

- Current: Simply utilize "current" level of support provided by DOI at no direct cost to the tribe; report any instances of probable violations to BIA Superintendent for action by GS Supervisor

- Improvement: Augment "minimum" level of activity performance by hiring a tribal petroleum engineer to perform inspections more frequently (e.g., monthly rather than quarterly "detailed" inspections).

- Improvement: Adopt tribal ordinance setting forth performance standards for operations, inspections, and enforcement: 
EXHIBIT IV-17

EXAMPLE OF AN ORGANIZATIONAL FORMAT FOR MODEL III

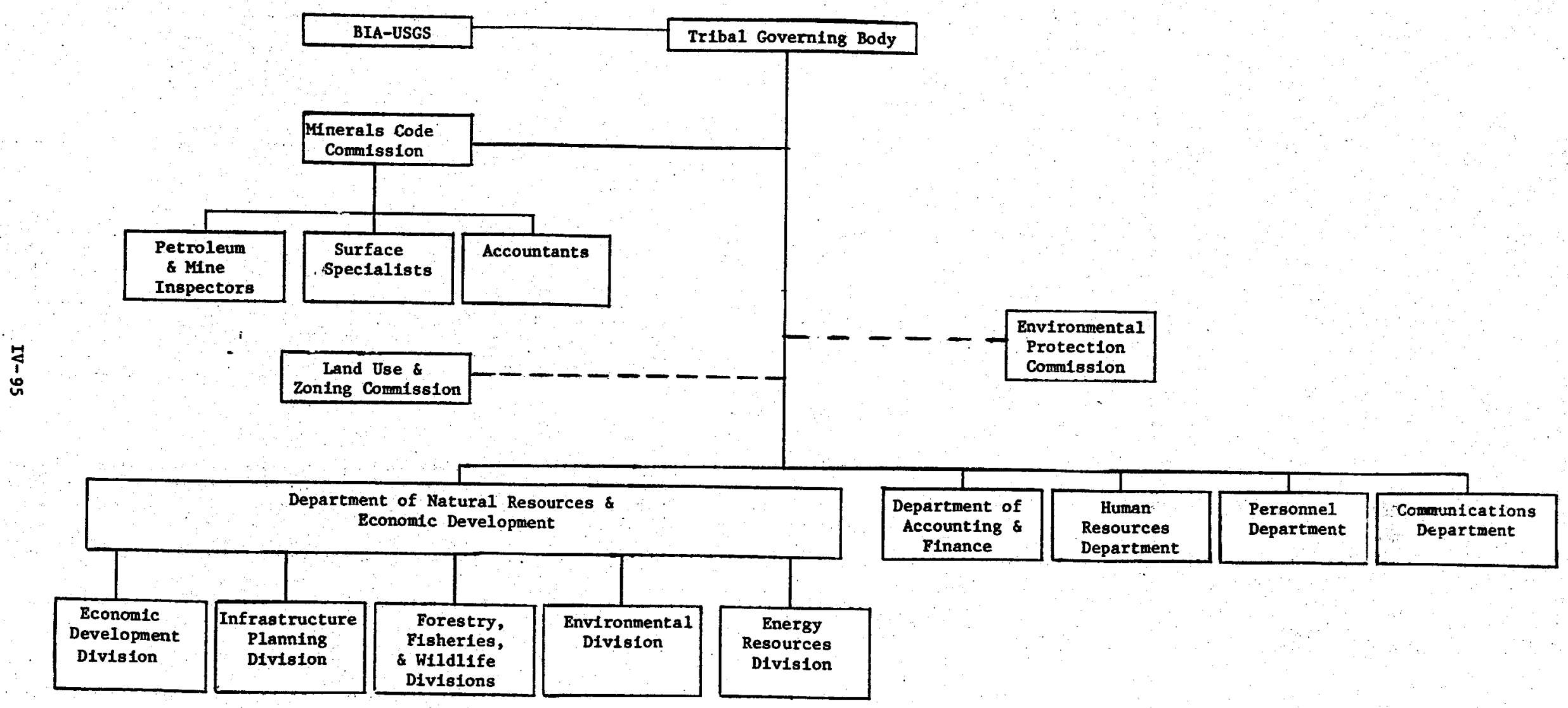

